Review

\title{
Exploring the Topological Landscape Exhibited by Binary Zinc-triad 1,1-dithiolates
}

\author{
Edward R.T. Tiekink \\ Research Centre for Crystalline Materials, School of Science and Technology, Sunway University, \\ No. 5 Jalan Universiti, Bandar Sunway 47500, Selangor Darul Ehsan, Malaysia; edwardt@sunway.edu.my; \\ Tel.: +60-3-7491-7181
}

Received: 14 June 2018; Accepted: 9 July 2018; Published: 14 July 2018

\begin{abstract}
The crystal chemistry of the zinc-triad binary 1,1-dithiolates, that is, compounds of xanthate $\left[{ }^{-} \mathrm{S}_{2} \mathrm{COR}\right]$, dithiophosphate $\left[{ }^{-} \mathrm{S} 2 \mathrm{P}(\mathrm{OR})_{2}\right]$, and dithiocarbamate $\left[{ }^{-} \mathrm{S}_{2} \mathrm{CNR}_{2}\right]$ ligands, is reviewed. Owing to a wide range of coordination modes that can be adopted by 1,1-dithiolate anions, such as monodentate, chelating, $\mu_{2}$-bridging, $\mu_{3}$-bridging, etc., there exists a rich diversity in supramolecular assemblies for these compounds, including examples of zero-, one-, and two-dimensional architectures. While there are similarities in structural motifs across the series of 1,1-dithiolate ligands, specific architectures are sometimes found, depending on the metal centre and/or on the 1,1-dithiolate ligand. Further, an influence of steric bulk upon supramolecular aggregation is apparent. Thus, bulky $\mathrm{R}$ groups generally preclude the close approach of molecules in order to reduce steric hindrance and therefore, lead to lower dimensional aggregation patterns. The ligating ability of the 1,1-dithiolate ligands also proves crucial in determining the extent of supramolecular aggregation, in particular for dithiocarbamate species where the relatively greater chelating ability of this ligand reduces the Lewis acidity of the zinc-triad element, which thereby reduces its ability to significantly expand its coordination number. Often, the functionalisation of the organic substituents in the 1,1-dithiolate ligands, for example, by incorporating pyridyl groups, can lead to different supramolecular association patterns. Herein, the diverse assemblies of supramolecular architectures are classified and compared. In all, 27 structurally distinct motifs have been identified.
\end{abstract}

Keywords: crystal engineering; coordination polymers; structural chemistry; zinc; cadmium; mercury; xanthate; dithiophosphate; dithiocarbamate

\section{Introduction}

The monofunctional 1,1-dithiolate ligands included in this review are the most well-studied of this class of ligand and have been around for a long time [1]; the chemical structures for the anions covered in this review are illustrated in Figure 1. The first of these, the dithiocarbonate anion, comprises alkyl esters of dithiocarbonic acid, $(\mathrm{RO}) \mathrm{C}(=\mathrm{S}) \mathrm{SH}$, which are quite unstable, but their alkali metal salts are both stable and easily prepared, usually from the reaction of $\mathrm{ROH}, \mathrm{CS}_{2}$, and $\mathrm{MOH}$. The common name for these anions is "xanthates". While this term is useful to distinguish these anions from the dithiocarbamates (see below), the name xanthate was actually introduced by the Danish chemist Zeise around 1820. The name is derived from the Greek "xanthos" and was coined in response to the yellow appearance of lead xanthates [2]. Dithiophosphates made their appearance about one century later, being made from the reaction of $\mathrm{P}_{2} \mathrm{~S}_{5}, \mathrm{ROH}$, and a base [3]. Particularly pertinent to this review is the fact that zinc(II) dithiophosphates came to the fore in the 1940's as a versatile class of compounds that were employed in various oils and grease as anti-wear additives, as corrosion inhibitors, and even function as anti-oxidants [4]. The aetiology of the dithiocarbamates is not as well defined [5], as opposed to xanthates and dithiophosphates. Dithiocarbamates have probably been 
around for over 150 years as Dobus is reported to have described the synthesis of dithiocarbamic acids in 1850 [6] and Delépine, the synthesis of metal salts of dithiocarbamates in 1907 [7].<smiles>[R]OC(=S)SC</smiles>

(a)<smiles>[R]OP([R])(=S)SC</smiles>

(b)<smiles>[R]N([R])C(=S)SC</smiles>

(c)

Figure 1. Chemical diagrams for 1,1-dithiolate ligands covered in this survey: (a) xanthate (O-alkyldithiocarbonate); (b) dithiophosphate; and (c) dithiocarbamate. $\mathrm{R}, \mathrm{R}^{\prime}$ = alkyl, aryl.

While this bibliographic review has as its focus the structural characteristics of the binary zinc-triad 1,1-dithiolates, it should be acknowledged that many investigations into these compounds were motivated by a broad range of practical applications such as their use as lubricants, pesticides, in the vulcanisation of rubber, beneficiation reagents of minerals, biological remediation of toxic elements, synthetic precursors for chemical vapour deposition of metal sulphide nanomaterials, and even in medicine as potential therapeutics. In short, the utility of this class of compound has ensured that many $X$-ray structural studies have been conducted over recent decades. Summaries of the applications and structural chemistry of the binary zinc-triads are found in early reviews on metal 1,1-dithiolates [8-10], in general reviews covering specific classes of 1,1-dithiolate anions [5,11-15], and in more specialist reviews dedicated to the zinc-triad elements only [16,17], with the last of these published in 2003. Since then, interest in these compounds has not waned and it is opportune to summarise the known structures at this time, especially as new structural motifs have been discovered over the past 15 years (see below).

\section{Methodology and Organisation}

As for a recent bibliographic survey on zinc and cadmium 1,1-dithiolates with potentially bridging bipyridyl-type ligands [18], the structures included in this survey were extracted in the form of crystallographic information files (CIF's) from the Cambridge Structural Database (CSD, Version 5.39, November 2017 release) [19]. Data were routinely analysed using PLATON [20] and original diagrams were drawn with the graphics program, DIAMOND [21]. The review is arranged so that xanthate structures are discussed first, followed by dithiophosphates and then dithiocarbamates. Within each of these categories, zinc structures are discussed before cadmium and mercury structures. Then, the structures are usually discussed in terms of the smallest $R$ substituent to the largest. The focus of the discussion is upon a description of the modes of coordination of the 1,1-dithiolate ligands leading to the resultant aggregation patterns. The interested reader is referred to the original publication for precise details of geometric parameters, which are not discussed in detail. Similarly, descriptions of molecular packing of the aggregates are not included. In all, among the xanthates, there are four, six, and 10 zinc-, cadmium-, and mercury-containing structures, respectively. For dithiophosphates there are four, seven, and four examples, and for the more numerous dithiocarbamates, there are 65,41 , and 44 examples, respectively.

\section{Discussion}

\subsection{Zinc-Triad Binary Xanthate Structures}

There are four, six, and 10 zinc, cadmium, and mercury structures to be described in this category. Starting from zinc, with three distinct structural motifs, it is obvious that an enormous structural diversity is evident among the known crystal structures as, often for these compounds, the xanthate ligand adopts a bidentate bridging mode of coordination. The compounds, coordination donor sets, and structural motifs/designations are summarised in Table 1. 
Table 1. Summary of the general features of $\mathrm{M}\left(\mathrm{S}_{2} \mathrm{COR}\right)_{2}, \mathrm{M}=$ zinc (1-4), cadmium (5-10), and mercury (11-20), structures.

\begin{tabular}{cccccc}
\hline Compound & $\mathbf{R} / \mathbf{R}^{\prime}$ & Donor set & Motif & Designation & Ref. \\
\hline $\mathbf{1}$ & $\mathrm{Et}$ & $\mathrm{S}_{4}$ & layer & $\mathrm{A}$ & {$[22]$} \\
$\mathbf{2}$ & $\mathrm{n}-\mathrm{Pr}$ & $\mathrm{S}_{4}$ & chain & $\mathrm{B}$ & {$[23]$} \\
$\mathbf{3}$ & $\mathrm{i}-\mathrm{Pr}$ & $\mathrm{S}_{4}$ & tetramer & $\mathrm{C}$ & {$[24]$} \\
$\mathbf{4}^{1}$ & $\mathrm{n}-\mathrm{Bu}$ & $\mathrm{S}_{4}$ & tetramer & $\mathrm{C}$ & {$[25]$} \\
$\mathbf{5}$ & $\mathrm{Me}$ & $\mathrm{S}_{6}$ & chain & $\mathrm{D}$ & {$[26]$} \\
$\mathbf{6}^{2}$ & $\mathrm{Et}$ & $\mathrm{S}_{4}$ & layer & $\mathrm{A}$ & {$[27]$} \\
$\mathbf{7}^{3}$ & $\mathrm{Et}$ & $\mathrm{S}_{4}$ & layer & $\mathrm{A}$ & {$[28]$} \\
$\mathbf{8}$ & $\mathrm{i}-\mathrm{Pr}$ & $\mathrm{S}_{4}$ & layer & $\mathrm{A}$ & {$[29,30]$} \\
$\mathbf{9}$ & $\mathrm{n}-\mathrm{Bu}$ & $\mathrm{S}_{4}$ & layer & $\mathrm{A}$ & {$[31]$} \\
$\mathbf{1 0}$ & $\mathrm{CH} \mathrm{CH}_{2} \mathrm{OMe}$ & $\mathrm{S}_{6}$ & chain & $\mathrm{D}$ & {$[32]$} \\
$\mathbf{1 1}$ & $\mathrm{Me}$ & $\mathrm{S}_{3}$ & chain & $\mathrm{E}$ & {$[33]$} \\
$\mathbf{1 2}$ & $\mathrm{Et}$ & $\mathrm{S}_{4}$ & layer & $\mathrm{A}$ & {$[34]$} \\
$\mathbf{1 3}$ & $\mathrm{Et}$ & $\mathrm{S}_{4}$ & layer & $\mathrm{A}$ & {$[35]$} \\
$\mathbf{1 4}$ & $\mathrm{n}-\mathrm{Pr}$ & $\mathrm{S}_{4}$ & layer & $\mathrm{A}$ & {$[36]$} \\
$\mathbf{1 5}$ & $\mathrm{i}-\mathrm{Pr}$ & $\mathrm{S}_{4}$ & layer & $\mathrm{F}$ & {$[37]$} \\
$\mathbf{1 6}$ & $\mathrm{n}-\mathrm{Bu}$ & $\mathrm{S}_{4}$ & layer & $\mathrm{A}$ & {$[38]$} \\
$\mathbf{1 7}$ & $(\mathrm{CH})_{2} \mathrm{C}(\mathrm{H}) \mathrm{Me}_{2}$ & $\mathrm{~S}_{4}$ & layer & $\mathrm{A}$ & {$[38]$} \\
$\mathbf{1 8}$ & $\left(\mathrm{CH}_{2}\right)_{2} \mathrm{CMe} \mathrm{S}_{3}$ & $\mathrm{~S}_{4}$ & layer & $\mathrm{A}$ & {$[38]$} \\
$\mathbf{1 9}$ & $\mathrm{Pent}$ & $\mathrm{S}_{4}$ & layer & $\mathrm{A}$ & {$[38]$} \\
$\mathbf{2 0}$ & $\mathrm{C}(\mathrm{H})\left[\left(\mathrm{CH}_{2}\right)_{2}\right]_{2} \mathrm{NCH}_{2} \mathrm{Ph}$ & $\mathrm{S}_{5}$ & chain & $\mathrm{G}$ & {$[39]$} \\
\hline
\end{tabular}

${ }^{1}$ Three benzene molecules of solvation per tetramer; ${ }^{2}$ Pa polymorph; ${ }^{3} \mathrm{P} 2{ }_{1} / \mathrm{c}$ polymorph; ${ }^{4} \mathrm{P} 2_{1}$ polymorph.

\subsubsection{Zinc Xanthates}

There are four binary zinc xanthate structures in this category, 1-4 [22-25], and key features of these are summarised in Table 1 along with the other cadmium and mercury structures included in this Section. In 1, that is, with $\mathrm{R}=\mathrm{Et}$ [22], both xanthate ligands are bidentate, bridging two zinc centres laterally, with the result that a two-dimensional array ensues. As shown in Figure 2a, the layer, with a flat topology, comprises interconnected, 16 -membered $\{-\mathrm{ZnSCS}\}_{4}$ rings. The zinc atom exists within an $\mathrm{S}_{4}$ donor set with each sulphur atom derived from a different xanthate ligand; the $S_{4}$ coordination geometry approximates a tetrahedron. This structural motif, motif $\mathbf{A}$, is repeated in several cadmium and many mercury analogues (see below). Crucial for the discussion below, is the observation that the ethyl groups are directed above and below the layer.

In what might be thought of as a trivial chemical change, that is, changing $\mathrm{R}=$ ethyl in $\mathbf{1}$ to $\mathrm{n}$-Pr in 2 [23], a major structural change is brought about, which is unprecedented in the analogous chemistry of transition metal xanthates [11-13]. The common features of the two structures are tetrahedral $S_{4}$ coordination geometries and the formation of 16-membered $\{-\mathrm{ZnSCS}\}_{4}$ rings. However, in the case of 2 , there are both bridging and chelating xanthate ligands. The observed supramolecular chain comprises corner shared 16-membered $\{-\mathrm{ZnSCS}\}_{4}$ rings, as shown in Figure $2 \mathrm{~b}$, and is assigned as structural motif $\mathbf{B}$. Yet another major change in structure is found in isomeric 3, in which the straight chains of $\mathbf{2}$ are replaced by branched i-Pr groups [24]. As for $\mathbf{1}$ and 2, $\mathrm{S}_{4}$-tetrahedra and 16-membered $\{-\mathrm{ZnSCS}\}_{4}$ rings prevail in the structure of 3 , but the clear difference is evident from Figure 2c, namely, the structure is an isolated tetramer, motif $\mathbf{C}$. The different structures arise owing to the different ratios of bridging and chelating xanthate ligands: in 1, all ligands are bridging, in 2 the ratio is 2:1, and in 3 there are equal numbers of bridging and chelating xanthate ligands. A qualitative explanation has been offered to rationalise the appearance of the three distinct structural motifs described thus far. This explanation is based on the relative steric bulk of the R groups. In short, the bulkier the $\mathrm{R}$ substituent, the less likely it is that supramolecular aggregation will occur. This concept is now well established in the structural chemistry of main group element 1,1-dithiolates [17,40-42] and in the structural chemistry of related organotin carboxylates [43-45], where bulky groups can disrupt 
secondary bonding interactions [18,46-48]. Further, it should be stressed that the nature of $R$, at least that present in the overwhelming majority of zinc-triad xanthate structures, does not exert a significant influence upon the electronic structure of the xanthate anion [49]. In the present series, the relatively bulky i-propyl groups define a three-dimensional exclusion zone around the tetramer in 3 , precluding additional bridging. In 2 , the exclusion zone defined by the n-propyl groups is two-dimensional so that chains can be formed in the third dimension. Finally, in $\mathbf{1}$, there is a one-dimensional exclusion zone leading to the layer motif. The final structure in this category, namely $\left[\mathrm{Zn}\left(\mathrm{S}_{2} \mathrm{CO}-\mathrm{n}-\mathrm{Bu}\right)_{2}\right]_{4}(4)$, was isolated as a benzene solvate [25]. The structural motif is as for $\mathbf{1}$, that is, layer motif, $\mathbf{A}$.

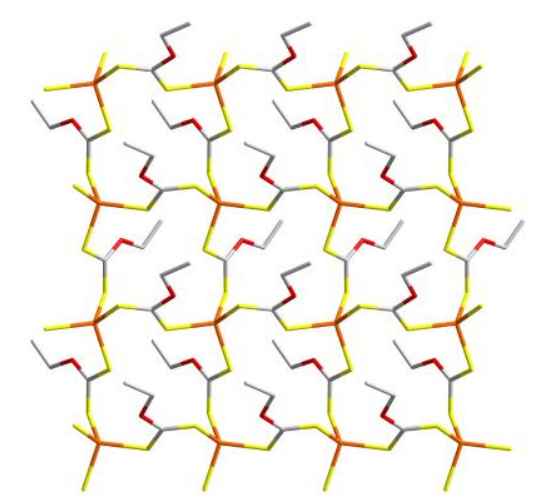

(a)

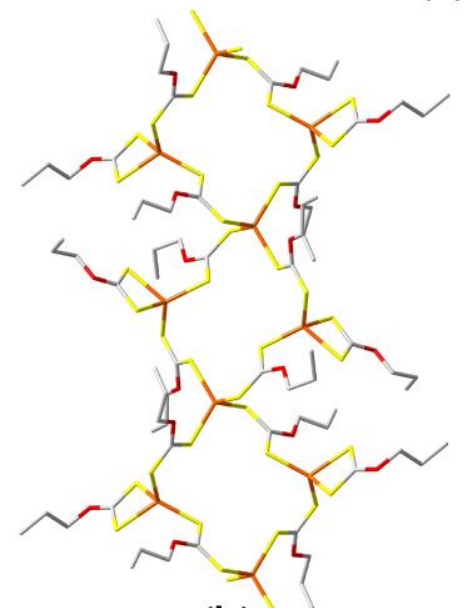

(b)

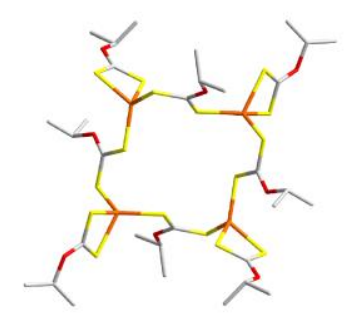

(c)

Figure 2. Aggregation in the crystals of (a) $\left[\mathrm{Zn}\left(\mathrm{S}_{2} \mathrm{COEt}\right)_{2}\right]_{\mathrm{n}}(\mathbf{1}) ;(\mathbf{b})\left[\mathrm{Zn}\left(\mathrm{S}_{2} \mathrm{CO}-\mathrm{n}-\mathrm{Pr}\right)_{2}\right]_{\mathrm{n}}$ (2); and (c) $\left[\mathrm{Zn}\left(\mathrm{S}_{2} \mathrm{CO}-\mathrm{i}-\mathrm{Pr}\right)_{2}\right]_{4}$ (3). Colour code in this and subsequent diagrams: zinc or cadmium or mercury, orange; sulphur, yellow; oxygen, red, carbon, grey. Non-acidic hydrogen atoms and solvent molecules have been omitted in all diagrams.

\subsubsection{Cadmium Xanthates}

There are five different xanthate compounds to be described in this Section, 5-10 [26-31], with structures 6 and 7 being polymorphs. The immediate coordination geometry of the cadmium centre in $\left[\mathrm{Cd}\left(\mathrm{S}_{2} \mathrm{COMe}\right)_{2}\right]_{n}$ (5) [26] is square-planar, a geometry defined by four sulphur atoms derived from two chelating xanthate ligands, Figure 3a; the cadmium atom lies on a crystallographic centre of inversion. Significant supramolecular aggregation occurs via secondary $\mathrm{Cd} \cdots \mathrm{S}$ bonding, leading to a $4+2$ distorted octahedral coordination geometry. It should be noted that the $\mathrm{Cd}-\mathrm{S}$ bond lengths in the square-plane are not that much shorter than those in the axial positions, that is, $2.64 \AA$ compared with $2.89 \AA$. The result is the formation of a linear supramolecular chain and is designated as structural motif $\mathbf{D}$. Structures 6-9 uniformly adopt layer motif $\mathbf{A}$ in the solid-state, but with minor variations in 
the orientations of the alkyl substituents and in the geometric parameters. Structures 6 [27] and 7 [28] have the common composition $\left[\mathrm{Cd}\left(\mathrm{S}_{2} \mathrm{COEt}\right)_{2}\right]_{\mathrm{n}}$ but, are polymorphs, crystallizing in the $\mathrm{Pa}$ and $\mathrm{P} 2_{1} / \mathrm{c}$ space groups, respectively. The relationship between the polymorphs is readily seen from the views normal to the layers shown in Figure 3b,c. In 6, the ethyl substituents are orientated to leave voids within the 16 -membered $\{-\mathrm{CdSCS}\}_{4}$ rings. While this pattern is also apparent in Figure $3 \mathrm{c}$ for 7 , this only occurs in alternate rows going across the page, and the ethyl groups in the other rows are orientated to block the voids in the rings. This change in symmetry is reflected in the doubling of the relevant crystal axis in 7 compared with 6 . In $\left[\mathrm{Cd}\left(\mathrm{S}_{2} \mathrm{CO}-\mathrm{i}-\mathrm{Pr}\right)_{2}\right]_{\mathrm{n}}(8)[29,30]$ and $\left[\mathrm{Cd}\left(\mathrm{S}_{2} \mathrm{CO}-\mathrm{n}-\mathrm{Bu}\right)_{2}\right]_{\mathrm{n}}(\mathbf{9})[31]$, the same layer motif appears, with that of $\mathbf{8}$ being the only example with the cadmium atom lying on a special position, in this case a 2-fold axis symmetry, leading to an aesthetically pleasing two-dimensional array, Figure 3d. The last structure in this section, $\left[\mathrm{Cd}\left(\mathrm{S}_{2} \mathrm{COCH}_{2} \mathrm{CH}_{2} \mathrm{OMe}\right)_{2}\right]_{n}$ (10) [32], closely resembles the structure of 5 , being a linear supramolecular polymer with a $4+2$ coordination geometry for the cadmium atom which lies on a centre of inversion; this is motif $\mathbf{D}$. In this case, there is a greater disparity in the $\mathrm{Cd}-\mathrm{S}$ bond lengths compared to those in 5, with those in the square-plane of 2.63 and $2.64 \AA$ being significantly shorter than those in the axial positions of $3.02 \AA$.

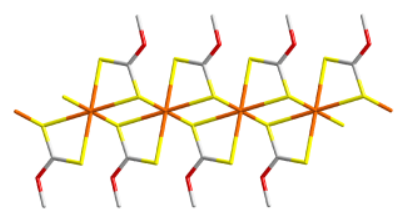

(a)

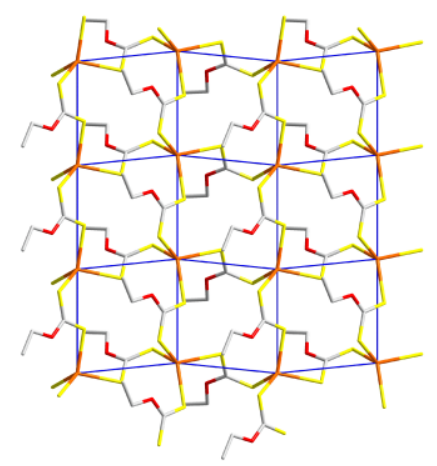

(b)

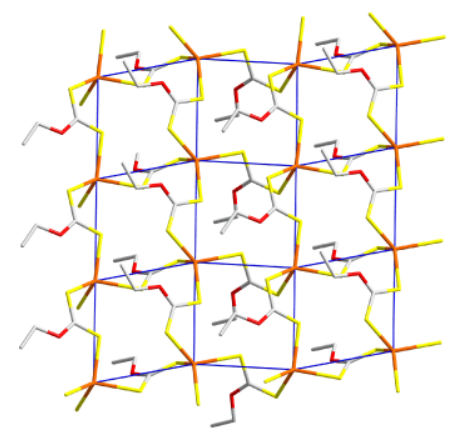

(c)

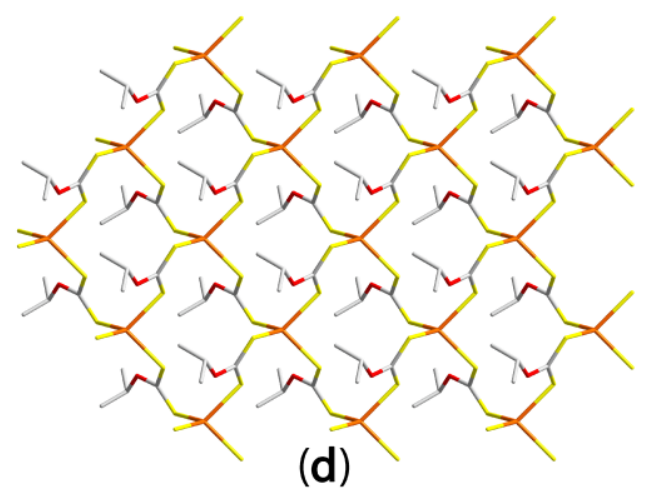

Figure 3. Aggregation in the crystals of $(\mathbf{a})\left[\mathrm{Cd}\left(\mathrm{S}_{2} \mathrm{COMe}\right)_{2}\right]_{\mathrm{n}}(\mathbf{5}) ;(\mathbf{b})\left[\mathrm{Cd}\left(\mathrm{S}_{2} \mathrm{COEt}\right)_{2}\right]_{\mathrm{n}}(\mathbf{6}) ;(\mathbf{c})\left[\mathrm{Cd}\left(\mathrm{S}_{2} \mathrm{COEt}\right)_{2}\right]_{\mathrm{n}}$ (7); and (d) $\left[\mathrm{Cd}\left(\mathrm{S}_{2} \mathrm{CO}-\mathrm{i}-\mathrm{Pr}\right)_{2}\right]_{\mathrm{n}}(\mathbf{8})$.

\subsubsection{Mercury Xanthates}

There are 10 mercury xanthate structures to be described in this Section, 11-20 [33-39], with structures 12 and 13 being polymorphs. A new structural motif, motif E, is realised in the 
crystal of $\left[\mathrm{Hg}\left(\mathrm{S}_{2} \mathrm{COMe}\right)_{2}\right]_{n}(\mathbf{1 1})$ [33], being based on a helical chain and propagated by crystallographic $2_{1}$ symmetry, Figure 4a. Here, one xanthate ligand is bidentate bridging albeit asymmetrically $(\mathrm{Hg}-\mathrm{S}$ : 2.38 and $2.92 \AA$ ), while the other is monodentate with $\mathrm{Hg}-\mathrm{S}$ of $2.37 \AA$. The two sulphur atoms forming the shorter bond lengths are linearly disposed (S-Hg-S is $165^{\circ}$ ), while the less strongly bound sulphur is in a position orthogonal to the $\mathrm{S}-\mathrm{Hg}-\mathrm{S}$ vector so that the mercury atom has a (planar) T-shaped geometry; the two proximate intra-chain oxygen atoms are disposed well above the $\mathrm{HgS}_{3}$ plane and with $\mathrm{Hg} \cdots$ O separations of $2 \times 2.93 \AA$ are not considered as significant bonding interactions [33]. Both $\mathrm{P} 2{ }_{1}$ (12) [34] and $\mathrm{P} 2_{1} / \mathrm{c}$ (13) [35] polymorphs of $\left[\mathrm{Hg}\left(\mathrm{S}_{2} \mathrm{COEt}\right)_{2}\right]_{n}$ have very similar structures and unit cell dimensions, but with the c-axis in $\mathbf{1 3}$ being approximately double the a-axis in $\mathbf{1 2}$. Each adopts the two-dimensional motif, motif $\mathbf{A}$. The major difference between the polymorphs rests with the symmetry of the two-dimensional grid defined by the mercury atoms, which is marginally squarer in appearance in $\mathbf{1 2}$, as judged by the distances between diagonally opposite mercury atoms within the 16-membered $\{-\mathrm{HgSCS}\}_{4}$ rings, that is, 6.90 and $9.10 \AA$ for $\mathbf{1 2}$ and 6.69 and $9.30 \AA$ for $\mathbf{1 3}$, indicating that the latter has a more diamond-like appearance. The structures of 12 and 13, with open or accessible voids in the 16-membered rings, resemble the situation in $\left[\mathrm{Zn}\left(\mathrm{S}_{2} \mathrm{COEt}\right)_{2}\right]_{\mathrm{n}}(\mathbf{1})[22]$ and $\left[\mathrm{Cd}\left(\mathrm{S}_{2} \mathrm{COEt}\right)_{2}\right]_{\mathrm{n}}$ (6) [27], Pa polymorph, meaning $\left[\mathrm{Cd}\left(\mathrm{S}_{2} \mathrm{COEt}\right)_{2}\right]_{n} 7$ [28], the $\mathrm{P} 2_{1} / c$ polymorph, is the exceptional structure, with half the voids being partially blocked. It is noted that there are no correlations between the space group and congestion about the voids in the 16-membered rings.
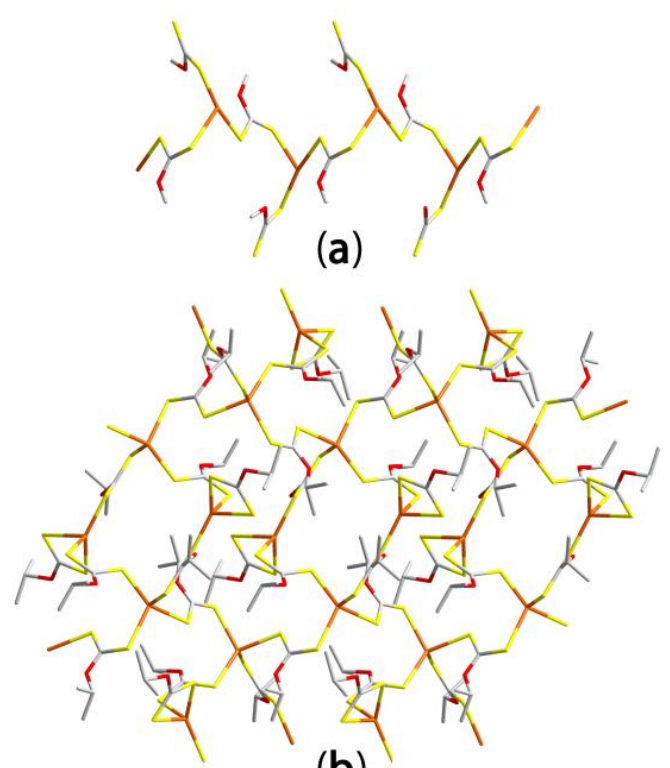

(b)

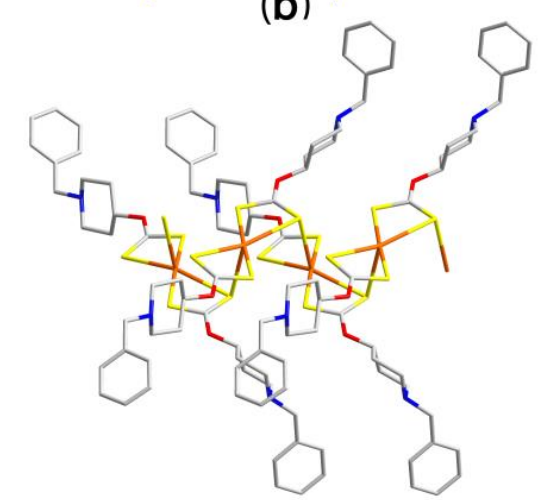

(c)

Figure 4. Aggregation in the crystals of (a) $\left[\mathrm{Hg}\left(\mathrm{S}_{2} \mathrm{COMe}\right)_{2}\right]_{\mathrm{n}}(\mathbf{1 1})$; (b) $\left[\mathrm{Hg}\left(\mathrm{S}_{2} \mathrm{CO}-\mathrm{i}-\mathrm{Pr}\right)_{2}\right]_{\mathrm{n}}$ (15); and (c) $\left[\mathrm{Hg}\left\{\mathrm{S}_{2} \mathrm{COC}(\mathrm{H})\left[\left(\mathrm{CH}_{2}\right)_{2}\right]_{2} \mathrm{NCH}_{2} \mathrm{Ph}\right\}_{2}\right]_{\mathrm{n}}$ (20). Additional colour code: nitrogen, blue. 
Two-dimensional arrays are also found in the crystals of $\left[\mathrm{Hg}\left(\mathrm{S}_{2} \mathrm{COR}\right)_{2}\right]_{\mathrm{n}}$, for $\mathrm{R}=\mathrm{n}-\mathrm{Pr}$ (14) [36], i- $\operatorname{Pr}$ (15) [37], n-Bu (16), $\mathrm{CH}_{2} \mathrm{CH}_{2} \mathrm{C}(\mathrm{H}) \mathrm{Me}_{2}$ (17), $\mathrm{CH}_{2} \mathrm{CH}_{2} \mathrm{CMe}_{3}$ (18), and Pentyl (19) [38]. With the exception of 15, the structures adopt the common motif $\mathrm{A}$ and with obvious voids in the structure when viewed normal to the plane of the array; congestion obviously increases with the size of the $\mathrm{R}$ substituent, especially in $\mathbf{1 7}$ and 18. A new structural motif is found for $\left[\mathrm{Hg}\left(\mathrm{S}_{2} \mathrm{CO}-\mathrm{i}-\mathrm{Pr}\right)_{2}\right]_{\mathrm{n}}$ (15) [37], designated as $\mathbf{F}$. This motif has features found for the majority of the zinc-triad binary xanthates in that one of the two independent mercury atoms is tetrahedrally coordinated by four sulphur atoms derived from four bridging xanthate ligands, that is, characteristic of motif $\mathbf{A}$. By contrast, the second independent mercury atom has its tetrahedral $S_{4}$ donor set defined by a chelating xanthate ligand, as well as two sulphur atoms derived from two bridging xanthates, that is, reminiscent of the zinc xanthate motifs $\mathbf{B}$ and $\mathbf{C}$ (see above). As all bridging xanthate ligands extend laterally, the overall structure is two-dimensional, as shown in Figure $4 \mathrm{~b}$.

The final structure to be described in this section has a non-conventional oxygen-bound substituent, that is, 1-benzylpiperidin-4-yl to yield $\left[\mathrm{Hg}\left\{\mathrm{S}_{2} \mathrm{COC}(\mathrm{H})\left[\left(\mathrm{CH}_{2}\right)_{2}\right]_{2} \mathrm{NCH}_{2} \mathrm{Ph}\right\}_{2}\right]_{\mathrm{n}}$ (20) [39]. In the crystal, this is a coordination polymer with five-coordinate mercury atoms, Figure 4c. Thus, the mercury atom is coordinated by two chelating xanthate ligands, one of which simultaneously bridges a symmetry-related mercury atom to generate the chain. A measure of the nature of the coordination geometry for five-coordinate systems is the value of $\tau$, which is 0.0 for an ideal square-pyramidal geometry and 1.0 for an ideal trigonal-pyramid [50]. In 20, the $S_{5}$ coordination geometry approximates a square-pyramid with $\tau=0.20$. In this description, the less tightly bound sulphur atom involved in forming the bridge occupies the apical position. In acknowledgement of the different coordination mode/geometry of the linear coordination polymer in $\mathbf{2 0}$, this structure is assigned as motif $\mathbf{G}$.

\subsection{Zinc-Triad Binary Dithiophosphate Structures}

The zinc-triad binary dithiophosphates comprise the smallest number of structures of the 1,1-dithiolates surveyed herein. Nevertheless, new and unprecedented structural motifs occur, with the common feature of all motifs being an $\mathrm{S}_{4}$ donor set for the central element; all structures crystallised solvent-free. Data for the 15 zinc-triad binary dithiophosphate structures, 21-35 [51-63], discussed in this section are presented in Table 2.

Table 2. Summary of the general features of $\mathrm{M}\left[\mathrm{S}_{2} \mathrm{P}(\mathrm{OR})_{2}\right], \mathrm{M}=$ zinc (21-24), cadmium (25-31), and mercury (32-35), structures.

\begin{tabular}{cccccc}
\hline Compound & $\mathbf{R}$ & Donor set & Motif & Designation & Ref. \\
\hline $\mathbf{2 1}$ & $\mathrm{Me}$ & $\mathrm{S}_{4}$ & $\mathrm{H}$ & chain & {$[51]$} \\
$\mathbf{2 2}$ & $\mathrm{i}-\mathrm{Pr}$ & $\mathrm{S}_{4}$ & $\mathrm{I}$ & dimer & {$[52]$} \\
$\mathbf{2 3}$ & $\mathrm{i}-\mathrm{Bu}$ & $\mathrm{S}_{4}$ & $\mathrm{I}$ & dimer & {$[53]$} \\
$\mathbf{2 4}$ & $\mathrm{Cy}$ & $\mathrm{S}_{4}$ & $\mathrm{I}$ & dimer & {$[54]$} \\
$\mathbf{2 5}$ & $\mathrm{Me}$ & $\mathrm{S}_{4}$ & $\mathrm{~J}$ & chain & {$[55]$} \\
$\mathbf{2 6}$ & $\mathrm{n}-\mathrm{Pr}$ & $\mathrm{S}_{4}$ & $\mathrm{~J}$ & chain & {$[56]$} \\
$\mathbf{2 7}$ & $\mathrm{i}-\mathrm{Pr}$ & $\mathrm{S}_{4}$ & $\mathrm{I}$ & dimer & {$[52]$} \\
$\mathbf{2 8}$ & $\mathrm{n}-\mathrm{Bu}$ & $\mathrm{S}_{4}$ & $\mathrm{~J}$ & chain & {$[56]$} \\
$\mathbf{2 9}$ & $\mathrm{i}-\mathrm{Bu}$ & $\mathrm{S}_{4}$ & $\mathrm{~J}$ & chain & {$[57]$} \\
$\mathbf{3 0}$ & $\mathrm{s}-\mathrm{Bu}$ & $\mathrm{S}_{4}$ & $\mathrm{I}$ & dimer & {$[58]$} \\
$\mathbf{3 1}$ & $\mathrm{Cy}$ & $\mathrm{S}_{4}$ & $\mathrm{~K}$ & dimer & {$[59]$} \\
$\mathbf{3 2}$ & $\mathrm{Me}$ & $\mathrm{S}_{4}$ & $\mathrm{~A}$ & layer & {$[60]$} \\
$\mathbf{3 3}$ & $\mathrm{i}-\mathrm{Pr}$ & $\mathrm{S}_{4}$ & $\mathrm{~L}$ & chain & {$[61]$} \\
$\mathbf{3 4}$ & $\mathrm{i}-\mathrm{Pr}$ & $\mathrm{S}_{4}$ & $\mathrm{~L}$ & chain & {$[62]$} \\
35 & c-Pentyl & $\mathrm{S}_{4}$ & $\mathrm{~L}$ & chain & {$[63]$} \\
\hline
\end{tabular}

${ }^{1} \mathrm{C} 2 / \mathrm{c}$ polymorph; ${ }^{2} \mathrm{P} 2{ }_{1} / \mathrm{c}$ polymorph. 


\subsubsection{Zinc Dithiophosphates}

Of the four known zinc dithiophosphates, 21-24 [51-54], two distinct and thus far, unprecedented structural motifs, are observed. For the structure with the smallest $\mathrm{R}$ substituent, $\left\{\mathrm{Zn}\left[\mathrm{S}_{2} \mathrm{P}(\mathrm{OMe})_{2}\right]_{2}\right\}_{\mathrm{n}}$ (21) [51], a zig-zag supramolecular chain is formed in the crystal as the result of bidentate bridging dithiophosphate ligands propagated by glide symmetry matched by equal numbers of chelating ligands, Figure $5 \mathrm{a}$. This new motif is designated motif $\mathbf{H}$. The second motif for zinc dithiophosphates is found for each of $\left\{\mathrm{Zn}\left[\mathrm{S}_{2} \mathrm{P}(\mathrm{O}-\mathrm{i}-\mathrm{Pr})_{2}\right]_{2}\right\}_{2}$ (22) [52], $\left\{\mathrm{Zn}\left[\mathrm{S}_{2} \mathrm{P}(\mathrm{O}-\mathrm{i}-\mathrm{Bu})_{2}\right]_{2}\right\}_{2}$ (23) [53], and $\left\{\mathrm{Zn}\left[\mathrm{S}_{2} \mathrm{P}(\mathrm{OCy})_{2}\right]_{2}\right\}_{2}$ (24) [54], and also features equal numbers of bridging and chelating ligands, but in this case leading to a dimeric aggregate, as illustrated for $\mathbf{2 4}$ in Figure $5 \mathrm{~b}$. The aggregates in $\mathbf{2 2}$ and $\mathbf{2 4}$ have crystallographic 2 -fold symmetry while that in $\mathbf{2 3}$ approximates 2 -fold symmetry. This motif is assigned as motif $\mathbf{I}$. As indicated below, many of the zinc-triad dithiocarbamates adopt a very similar motif, but often

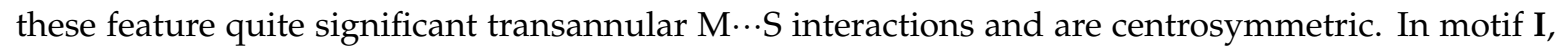
the zinc atom coordination geometries are distorted tetrahedrally based on $\mathrm{S}_{4}$ donor sets, indicating the absence of transannular $\mathrm{Zn} \cdots \mathrm{S}$ interactions.

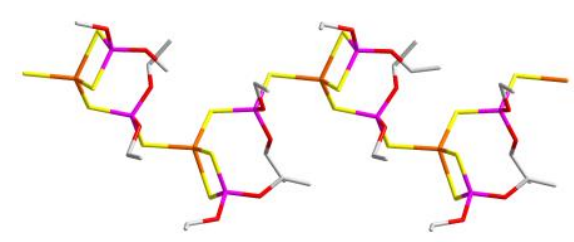

(a)

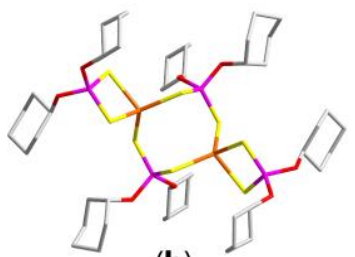

(b)

Figure 5. Aggregation in the crystals of (a) $\left\{\mathrm{Zn}\left[\mathrm{S}_{2} \mathrm{P}(\mathrm{OMe})_{2}\right]_{2}\right\}_{n}$ (21) and (b) $\left\{\mathrm{Zn}\left[\mathrm{S}_{2} \mathrm{P}(\mathrm{OCy})_{2}\right]_{2}\right\}_{2}$ (24). Additional colour code: phosphorus, pink.

\subsubsection{Cadmium Dithiophosphates}

There are seven structures in this category and these adopt two distinct structural motifs in the solid-state, one of which is new. The new motif, $\mathbf{J}$, is found in the crystals of four compounds, namely $\left\{\mathrm{Cd}\left[\mathrm{S}_{2} \mathrm{P}(\mathrm{OR})_{2}\right]_{2}\right\}_{\mathrm{n}}$ for $\mathrm{R}=\mathrm{Me}$ (25) [55], Figure 6a; n-Pr (26) [56]; n-Bu (28) [56]; and i-Bu (29) [57]. Here, all dithiophosphate ligands are bidentate bridging, leading to eight-membered $\{-\mathrm{SPSCd}\}_{2}$ rings that are linked at the cadmium atom to form a twisted chain; the chain in $\mathbf{2 5}$ has crystallographic 2-fold symmetry. The eight-membered ring in motif $\mathbf{J}$ has the form of a boat with two sulphur atoms above and two below the plane through the $\mathrm{Cd}_{2} \mathrm{P}_{2}$ atoms. The remaining three structures, $\left.\mathrm{Cd}\left[\mathrm{S}_{2} \mathrm{P}(\mathrm{OR})_{2}\right]_{2}\right\}_{2}$ for $\mathrm{R}$ = i-Pr (27) [52]; s-Bu (30) [58], Figure 6b; and Cy (31) [59], adopt motif I. A distinguishing feature of $\mathbf{3 1}$ is that the dimeric aggregate is disposed about a centre of inversion as opposed to 2-fold symmetry for $\mathbf{2 7}$ and $\mathbf{3 0}$. In order to distinguish between the two symmetries for the dimer, dimeric aggregates with 2-fold symmetry, approximate or crystallographically-imposed, are designated as I, while those disposed about a centre of inversion or close to this are designated as K. Finally, in terms of the two structural motifs adopted by cadmium dithiophosphates, that is, to a first approximation dimeric or polymeric, it is noted that for the three derivatives with branching at the alpha-carbon atom, the dimer form is adopted, again suggesting a significant steric influence in determining the ultimate motif found in the crystal. 

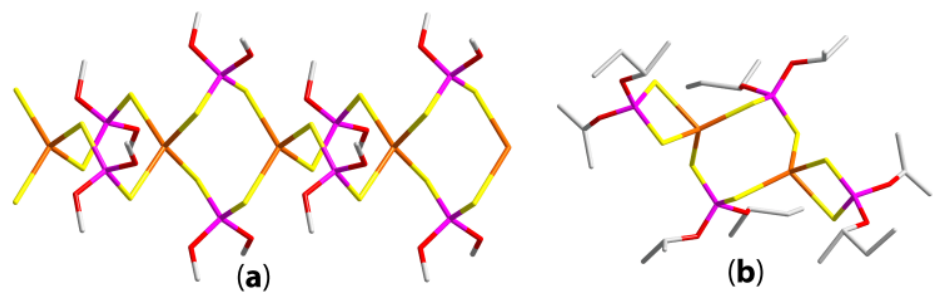

(b)

Figure 6. Aggregation in the crystals of (a) $\left\{\mathrm{Cd}\left[\mathrm{S}_{2} \mathrm{P}(\mathrm{OMe})_{2}\right]_{2}\right\}_{n}(\mathbf{2 5})$ and (b) $\left\{\mathrm{Cd}\left[\mathrm{S}_{2} \mathrm{P}(\mathrm{O}-\mathrm{s}-\mathrm{Bu})_{2}\right]_{2}\right\}_{2}(\mathbf{3 0})$.

\subsubsection{Mercury Dithiophosphates}

There are four structures to be described in this section, but only three compounds as a pair are polymorphic. The structure of $\left\{\mathrm{Hg}\left[\mathrm{S}_{2} \mathrm{P}(\mathrm{OMe})_{2}\right]_{2}\right\}_{n}$ (32) [60] is a two-dimensional layer as all dithiophosphate ligands are bidentate bridging. As seen in Figure $7 \mathrm{a}$, the resemblance between this structure, with edge-shared 16-membered $\{-\mathrm{HgSPS}\}_{4}$ rings, and those of many of the zinc-triad xanthates is obvious and accordingly, this is an example of motif $\mathbf{A}$. The three remaining examples, that is, polymorphic $\left\{\mathrm{Hg}\left[\mathrm{S}_{2} \mathrm{P}(\mathrm{O}-\mathrm{i}-\mathrm{Pr})_{2}\right]_{2}\right\}_{\mathrm{n}}$ (33) [61] and (34) [62], adopting $\mathrm{C} 2 / \mathrm{c}$ and $\mathrm{P} 2_{1} / \mathrm{c}$ space groups, respectively, and $\left\{\mathrm{Hg}\left[\mathrm{S}_{2} \mathrm{P}(\mathrm{O}-\mathrm{c}-\mathrm{Pentyl})_{2}\right]_{2}\right\}_{\mathrm{n}}$ (35) [63], Figure $7 \mathrm{~b}$, also adopt a previously described structural motif. Thus, linear chains arising from equal numbers of chelating and bridging dithiophosphate ligands are found, akin to motif $\mathbf{H}$. However, in motif $\mathbf{H}$, the chains have a zig-zag topology, whereas in 33-35, a helical topology is evident as the coordination polymers are propagated by $2_{1}$-screw symmetry in each case. In acknowledgment of the distinct topologies, those with $2_{1}$-screw symmetry are labelled as $\mathbf{L}$. The differences between the polymorphs of $\left\{\mathrm{Hg}_{\mathrm{g}}\left[\mathrm{S}_{2} \mathrm{P}(\mathrm{O}-\mathrm{i}-\mathrm{Pr})_{2}\right]_{2}\right\}_{n}$ primarily relate to differences in $\mathrm{Hg}-\mathrm{S}$ bond lengths, with the range of $\mathrm{Hg}-\mathrm{S}$ bond lengths in the $\mathrm{C} 2 / \mathrm{c}$ polymorph of 2.39-2.89 $\AA$ [61] being greater than in the $\mathrm{P} 2{ }_{1} / \mathrm{c}$ form of $2.44-2.83$, corresponding to $\Delta(\mathrm{Hg}-\mathrm{S})$ values of 0.50 and 0.39 , respectively.

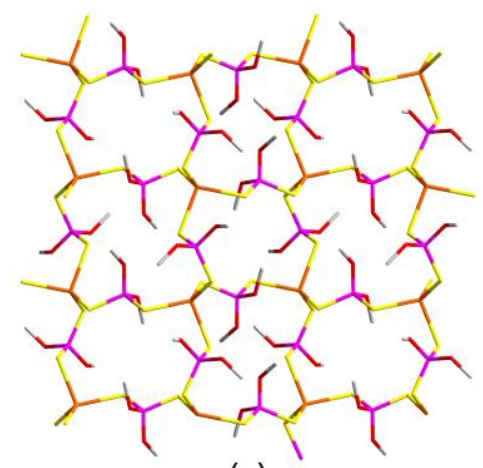

(a)

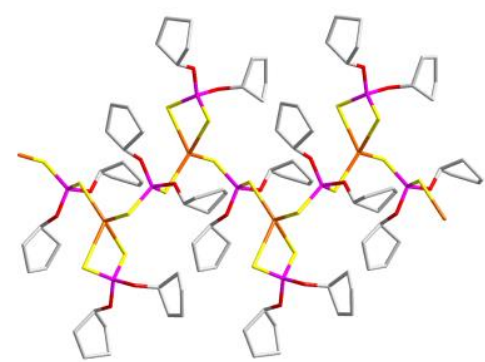

(b)

Figure 7. Aggregation in the crystals of (a) $\left\{\mathrm{Hg}\left[\mathrm{S}_{2} \mathrm{P}(\mathrm{OMe})_{2}\right]_{2}\right\}_{n}$ (32) and (b) $\left\{\mathrm{Hg}\left[\mathrm{S}_{2} \mathrm{P}(\mathrm{O}-\mathrm{c}-\mathrm{Pentyl})_{2}\right]_{2}\right\}_{\mathrm{n}}$ (35).

\subsection{Zinc-Triad Binary Dithiocarbamate Structures}

By far the most numerous structures included in this review are the zinc-triad binary dithiocarbamates. While these generally adopt mononuclear or more likely binuclear motifs (see below), the presence of a heteroatom in the organic substituents can lead to further aggregation in the solid-state.

\subsubsection{Zinc Dithiocarbamates}

Data for the $65 \mathrm{Zn}\left(\mathrm{S}_{2} \mathrm{CNRR}^{\prime}\right)_{2}$ structures discussed in this section, 36-100 [25,64-110], are collected in Table 3. The first motif noted is monomeric and designated $\mathbf{M}$. The zinc atom in those structures adopting motif $\mathbf{M}$ is chelated by two dithiocarbamate ligands which are generally coordinating in 
a symmetric mode, for example, 2.32 and $2.35 \AA$ in the structure of $\mathrm{Zn}\left(\mathrm{S}_{2} \mathrm{CNCy}_{2}\right)_{2}$ (37) [25], illustrated in Figure 8a. This structure has the zinc centre located on a 2-fold symmetry axis; similar symmetry is also found in 38 [65] and 44 [71]. The coordination geometry is based on distorted tetrahedral $\mathrm{S}_{4}$ environments as the $\mathrm{ZnS}_{2} \mathrm{C}$ chelate planes are approximately orthogonal to each other. The assignment of monomeric structures is based on the lack of intermolecular $\mathrm{Zn} \cdots \mathrm{S}$ associations less than the sum of the van der Waals radii of zinc and sulphur, taken as $4.05 \AA$ [20]. This is true for most of the examples, but in four structures, $\mathrm{Zn} \cdots \mathrm{S}$ less than the sum of the van der Waals radii is evident, that is, $42(3.93 \AA), 45(3.86 \AA), 39(3.58 \AA)$, and $43(3.44 \AA)$. Such alignment of molecules gives the potential for dimerization, leading to binuclear motifs $N(39)$ and $O(42,43$ and 45), as discussed below. Such a potential dimerization is illustrated in Figure $8 \mathrm{~b}$ for 39.

Table 3. Summary of the general features of $\mathrm{Zn}\left(\mathrm{S}_{2} \mathrm{CNRR}^{\prime}\right)_{2}$ structures 36-100.

\begin{tabular}{|c|c|c|c|c|c|}
\hline Compound & $\mathbf{R} / \mathbf{R}^{\prime}$ & Donor Set & Motif & Designation & Ref. \\
\hline 36 & $\mathrm{CH}_{2} \mathrm{CH}_{2} \mathrm{OMe} / \mathrm{CH}_{2} \mathrm{CH}_{2} \mathrm{OMe}$ & $\mathrm{S}_{4}$ & M & monomer & [64] \\
\hline 37 & Су/Сy & $\mathrm{S}_{4}$ & M & monomer & [25] \\
\hline 38 & Benzyl/Benzyl & $\mathrm{S}_{4}$ & M & monomer & [65] \\
\hline 39 & $\mathrm{Me} / \mathrm{Cy}$ & $\mathrm{S}_{4}$ & M & monomer & [66] \\
\hline 40 & $\mathrm{n}-\mathrm{Pr} / \mathrm{CH}(\mathrm{Me}) \mathrm{Et}$ & $\mathrm{S}_{4}$ & M & monomer & [67] \\
\hline 41 & $\mathrm{NRR}^{\prime}=3,4$-dihydroquinoline & $\mathrm{S}_{4}$ & M & monomer & [68] \\
\hline 42 & n-Bu/5-t-Bu-3-Me-2-OH-benzyl & $\mathrm{S}_{4}$ & M & monomer & [69] \\
\hline 43 & $\mathrm{CH}_{2} \mathrm{CH}_{2} \mathrm{OH} / \mathrm{CH}_{2}$ (ferrocenyl) & $\mathrm{S}_{4}$ & M & monomer & [70] \\
\hline 44 & $\left(\mathrm{CH}_{2}\right)_{3} \mathrm{OEt} / 3,5-$ di-t-Bu-4-OH-benzyl & $\mathrm{S}_{4}$ & M & monomer & [71] \\
\hline 45 & Benzyl $/ \mathrm{CH}_{2}(1-\mathrm{Me}$-pyrrol-2-yl) & $\mathrm{S}_{4}$ & M & monomer & [72] \\
\hline 46 & Benzyl/4-OMe-benzyl & $\mathrm{S}_{4}$ & M & monomer & [73] \\
\hline 47 & Benzyl/R ${ }^{11}$ & $\mathrm{~S}_{4}$ & M & monomer & [74] \\
\hline 48 & $\mathrm{CH}_{2}$ (4-OMe-phenyl)/ $\mathrm{CH}_{2}$ (2-furyl) & $\mathrm{S}_{4}$ & M & monomer & [75] \\
\hline 49 & $\mathrm{Me} / \mathrm{Me}$ & $\mathrm{S}_{4}+1$ & $\mathrm{~N}$ & dimer & [76] \\
\hline $50^{2}$ & $\mathrm{n}-\mathrm{Bu} / \mathrm{n}-\mathrm{Bu}$ & $\mathrm{S}_{4}+1$ & $\mathrm{~N}$ & dimer & [77] \\
\hline $51^{3}$ & $\mathrm{n}-\mathrm{Bu} / \mathrm{n}-\mathrm{Bu}$ & $\mathrm{S}_{4}+1$ & $\mathrm{~N}$ & dimer & [78] \\
\hline 52 & $\mathrm{Me} / \mathrm{CH}_{2}$ (ferrocenyl) & $\mathrm{S}_{4}+1$ & $\mathrm{~N}$ & dimer & [74] \\
\hline 53 & $\mathrm{Et} / \mathrm{Et}$ & $\mathrm{S}_{4}+1$ & $\mathrm{O}$ & dimer & [79] \\
\hline 54 & $\mathrm{n}-\mathrm{Pr} / \mathrm{n}-\mathrm{Pr}$ & $\mathrm{S}_{4}+1$ & $\mathrm{O}$ & dimer & [80] \\
\hline 55 & $\mathrm{i}-\operatorname{Pr} / \mathrm{i}-\mathrm{Pr}$ & $\mathrm{S}_{4}+1$ & $\mathrm{O}$ & dimer & [81] \\
\hline 56 & $\mathrm{CH}_{2} \mathrm{C}(\mathrm{H})=\mathrm{CH}_{2} / \mathrm{CH}_{2} \mathrm{C}(\mathrm{H})=\mathrm{CH}_{2}$ & $\mathrm{~S}_{4}+1$ & $\mathrm{O}$ & dimer & [82] \\
\hline $57^{4}$ & $\mathrm{CH}_{2} \mathrm{CH}_{2} \mathrm{OH} / \mathrm{CH}_{2} \mathrm{CH}_{2} \mathrm{OH}$ & $\mathrm{S}_{4}+1$ & $\mathrm{O}$ & dimer & [83] \\
\hline $58^{2}$ & $\mathrm{CH}_{2} \mathrm{CH}_{2} \mathrm{OH} / \mathrm{CH}_{2} \mathrm{CH}_{2} \mathrm{OH}$ & $\mathrm{S}_{4}+1$ & $\mathrm{O}$ & dimer & [84] \\
\hline $59^{5}$ & $\mathrm{CH}_{2} \mathrm{CH}_{2} \mathrm{OH} / \mathrm{CH}_{2} \mathrm{CH}_{2} \mathrm{OH}$ & $\mathrm{S}_{4}+1$ & $\mathrm{O}$ & dimer & [85] \\
\hline 60 & $\mathrm{R}+\mathrm{R}^{\prime}=\left(\mathrm{CH}_{2}\right)_{4}$ & $\mathrm{~S}_{4}+1$ & $\mathrm{O}$ & dimer & [86] \\
\hline 61 & $\mathrm{R}+\mathrm{R}^{\prime}=\left(\mathrm{CH}_{2}\right)_{5}$ & $\mathrm{~S}_{4}+1$ & $\mathrm{O}$ & dimer & [87] \\
\hline 62 & $\mathrm{R}+\mathrm{R}^{\prime}=\left(\mathrm{CH}_{2}\right)_{6}$ & $\mathrm{~S}_{4}+1$ & $\mathrm{O}$ & dimer & [88] \\
\hline 63 & $\mathrm{R}+\mathrm{R}^{\prime}=\left(\mathrm{CH}_{2}\right)_{5}-4-\mathrm{Me}$ & $\mathrm{S}_{4}+1$ & $\mathrm{O}$ & dimer & [89] \\
\hline 64 & $\mathrm{R}+\mathrm{R}^{\prime}=\left(\mathrm{CH}_{2}\right)_{5}-4-\mathrm{C}(=\mathrm{O}) \mathrm{OEt}$ & $\mathrm{S}_{4}+1$ & $\mathrm{O}$ & dimer & [72] \\
\hline $65^{6}$ & $\mathrm{R}+\mathrm{R}^{\prime}=\left(\mathrm{CH}_{2}\right)_{5}-4-\mathrm{C}(=\mathrm{O}) \mathrm{ON}\left[\mathrm{C}(=\mathrm{O}) \mathrm{CH}_{2}\right]_{2}$ & $\mathrm{~S}_{4}+1$ & $\mathrm{O}$ & dimer & [90] \\
\hline 66 & $\mathrm{R}+\mathrm{R}^{\prime}=\left(\mathrm{CH}_{2} \mathrm{CH}_{2}\right)_{2} \mathrm{NEt}$ & $\mathrm{S}_{4}+1$ & $\mathrm{O}$ & dimer & [91] \\
\hline 67 & $\mathrm{R}+\mathrm{R}^{\prime}=\left(\mathrm{CH}_{2} \mathrm{CH}_{2}\right)_{2} \mathrm{NPh}$ & $\mathrm{S}_{4}+1$ & $\mathrm{O}$ & dimer & [92] \\
\hline 68 & $\mathrm{R}+\mathrm{R}^{\prime}=\left(\mathrm{CH}_{2} \mathrm{CH}_{2}\right)_{2} \mathrm{NC}_{6} \mathrm{H}_{4}-3-\mathrm{OMe}$ & $\mathrm{S}_{4}+1$ & $\mathrm{O}$ & dimer & [93] \\
\hline 69 & $\mathrm{R}+\mathrm{R}^{\prime}=\left(\mathrm{CH}_{2} \mathrm{CH}_{2}\right)_{2} \mathrm{NC}_{6} \mathrm{H}_{4}-4-\mathrm{OMe}$ & $\mathrm{S}_{4}+1$ & $\mathrm{O}$ & dimer & [93] \\
\hline 70 & $\mathrm{Me} / \mathrm{Et}$ & $\mathrm{S}_{4}+1$ & $\mathrm{O}$ & dimer & [94] \\
\hline 71 & $\mathrm{Me} / \mathrm{n}-\mathrm{Pr}$ & $\mathrm{S}_{4}+1$ & $\mathrm{O}$ & dimer & [94] \\
\hline 72 & $\mathrm{Me} / \mathrm{i}-\mathrm{Pr}$ & $\mathrm{S}_{4}+1$ & $\mathrm{O}$ & dimer & [94] \\
\hline 73 & $\mathrm{Me} / \mathrm{n}-\mathrm{Bu}$ & $\mathrm{S}_{4}+1$ & $\mathrm{O}$ & dimer & [94] \\
\hline 74 & $\mathrm{Me} / \mathrm{Ph}$ & $\mathrm{S}_{4}+1$ & $\mathrm{O}$ & dimer & [95] \\
\hline $75^{7}$ & $\mathrm{Me} / \mathrm{CH}_{2} \mathrm{CH}_{2} \mathrm{OH}$ & $\mathrm{S}_{4}+1$ & $\mathrm{O}$ & dimer & [96] \\
\hline $76^{8}$ & $\mathrm{Me} / \mathrm{CH}_{2} \mathrm{CH}_{2} \mathrm{OH}$ & $\mathrm{S}_{4}+1$ & $\mathrm{O}$ & dimer & [83] \\
\hline 77 & $\mathrm{Me} / \mathrm{CH}_{2} \mathrm{C}(=\mathrm{O}) \mathrm{OMe}$ & $\mathrm{S}_{4}+1$ & $\mathrm{O}$ & dimer & [97] \\
\hline 78 & $\mathrm{Me} / \mathrm{CH}_{2} \mathrm{C}(\mathrm{H})(\mathrm{OMe})_{2}$ & $\mathrm{~S}_{4}+1$ & $\mathrm{O}$ & dimer & [98] \\
\hline $79^{9}$ & $\mathrm{Me} / \mathrm{R}^{29}$ & $\mathrm{~S}_{4}+1$ & $\mathrm{O}$ & dimer & [74] \\
\hline 80 & $\mathrm{Et} / \mathrm{i}-\mathrm{Pr}$ & $\mathrm{S}_{4}+1$ & $\mathrm{O}$ & dimer & [99] \\
\hline
\end{tabular}


Table 3. Cont.

\begin{tabular}{|c|c|c|c|c|c|}
\hline Compound & $\mathbf{R} / \mathbf{R}^{\prime}$ & Donor Set & Motif & Designation & Ref. \\
\hline 81 & $\mathrm{Et} / \mathrm{n}-\mathrm{Bu}$ & $\mathrm{S}_{4}+1$ & $\mathrm{O}$ & dimer & [100] \\
\hline 82 & $\mathrm{Et} / \mathrm{Cy}$ & $\mathrm{S}_{4}+1$ & $\mathrm{O}$ & dimer & [25] \\
\hline $83^{3}$ & $\mathrm{Et} / \mathrm{Ph}$ & $\mathrm{S}_{4}+1$ & $\mathrm{O}$ & dimer & [101] \\
\hline $84^{5}$ & $\mathrm{Et} / \mathrm{Ph}$ & $S_{4}+1$ & $\mathrm{O}$ & dimer & [102] \\
\hline 85 & $\mathrm{Et} / \mathrm{CH}_{2} \mathrm{CH}_{2} \mathrm{OH}$ & $\mathrm{S}_{4}+1$ & $\mathrm{O}$ & dimer & [83] \\
\hline 86 & n-Pr/i-Pr & $\mathrm{S}_{4}+1$ & $\mathrm{O}$ & dimer & [103] \\
\hline $87^{10}$ & $\mathrm{i}-\mathrm{Pr} / \mathrm{CH}_{2} \mathrm{CH}_{2} \mathrm{OH}$ & $\mathrm{S}_{4}+1$ & $\mathrm{O}$ & dimer & [96] \\
\hline 88 & $\mathrm{c}-\mathrm{Pr} / \mathrm{CH}_{2} \mathrm{C}_{6} \mathrm{H}_{4}-4-\mathrm{OMe}$ & $\mathrm{S}_{4}+1$ & $\mathrm{O}$ & dimer & [104] \\
\hline 89 & $\mathrm{n}-\mathrm{Bu} / \mathrm{Ph}$ & $\mathrm{S}_{4}+1$ & $\mathrm{O}$ & dimer & [105] \\
\hline 90 & Benzyl $/\left(\mathrm{CH}_{2}\right)_{13} \mathrm{Me}$ & $\mathrm{S}_{4}+1$ & $\mathrm{O}$ & dimer & [106] \\
\hline $91^{9}$ & Benzyl/R 29 & $\mathrm{~S}_{4}+1$ & $\mathrm{O}$ & dimer & {$[74]$} \\
\hline 92 & $\mathrm{CH}_{2}$ (2-furyl) $/ \mathrm{CH}_{2} \mathrm{C}_{6} \mathrm{H}_{4}-4-\mathrm{Cl}$ & $\mathrm{S}_{4}+1$ & $\mathrm{O}$ & dimer & [75] \\
\hline 93 & $\mathrm{CH}_{2}(2$-furyl $) / \mathrm{R}^{29}$ & $\mathrm{~S}_{4}+1$ & $\mathrm{O}$ & dimer & {$[74]$} \\
\hline 94 & $\mathrm{CH}_{2} \mathrm{C}_{6} \mathrm{H}_{4}-4-\mathrm{OMe} /\left(\mathrm{CH}_{2}\right)_{2} \mathrm{~N}\left(\mathrm{CH}_{2} \mathrm{CH}_{2}\right)_{2} \mathrm{O}$ & $\mathrm{S}_{4}+1$ & $\mathrm{O}$ & dimer & [74] \\
\hline \multirow[t]{2}{*}{95} & $\mathrm{i}-\mathrm{Bu} / \mathrm{i}-\mathrm{Bu}$ & $\mathrm{S}_{4}$ & M & monomer & [107] \\
\hline & & $\mathrm{S}_{4}+1$ & $\mathrm{O}$ & & \\
\hline 96 & $\mathrm{R}+\mathrm{R}^{\prime}=\left(\mathrm{CH}_{2}\right)_{4} \mathrm{NMe}$ & $\mathrm{NS}_{4}$ & $\mathrm{P}$ & polymer & [108] \\
\hline $97^{11}$ & Benzyl $/ \mathrm{CH}_{2}(3-p y)$ & $\mathrm{NS}_{4}$ & $\mathrm{Q}$ & dimer & {$[72]$} \\
\hline 98 & $\mathrm{CH}_{2}$ (ferrocenyl) $/ \mathrm{CH}_{2}$ (3-py) & $\mathrm{NS}_{4}$ & $\hat{Q}$ & dimer & [109] \\
\hline $99^{12}$ & $\mathrm{Et} / \mathrm{CH}_{2}(4-\mathrm{py})$ & $\mathrm{NS}_{4}$ & $\mathrm{P}$ & polymer & [110] \\
\hline $100^{13}$ & $\mathrm{CH}_{2}$ (ferrocenyl) $/ \mathrm{CH}_{2}$ (4-py) & $\mathrm{N}_{2} \mathrm{~S}_{4}$ & $\mathrm{R}$ & layer & [109] \\
\hline
\end{tabular}

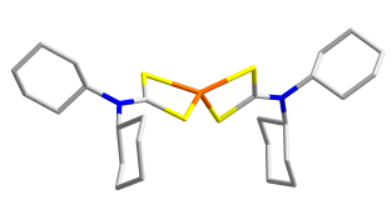

(a)

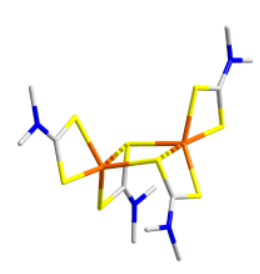

(c)

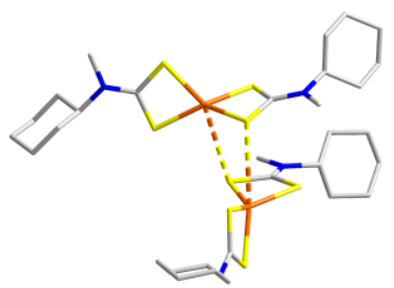

(b)

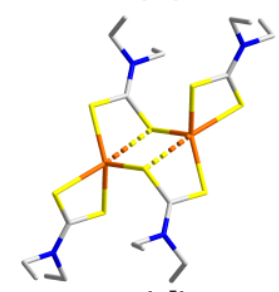

(d)

Figure 8. (a) Molecular structure of $\mathrm{Zn}\left(\mathrm{S}_{2} \mathrm{CNCy}_{2}\right)_{2}$ (37) where the the zinc atom lies on a 2-fold axis; (b) supramolecular association via $\mathrm{Zn}$...S interactions ( $3.58 \AA$ ) between two molecules disposed about a 2-fold axis of symmetry in the crystal of $\mathrm{Zn}\left[\mathrm{S}_{2} \mathrm{CN}(\mathrm{Me}) \mathrm{Cy}\right]_{2}$ (35); (c) molecular structure of $\left\{\mathrm{Zn}\left(\mathrm{S}_{2} \mathrm{CNMe}_{2}\right)_{2}\right\}_{2}$ (49) where the molecule has 2-fold symmetry; and (d) molecular structure of $\left\{\mathrm{Zn}\left(\mathrm{S}_{2} \mathrm{CNEt}_{2}\right)_{2}\right\}_{2}$ (53) where the molecule is disposed about a centre of inversion. The dashed bonds in (c) and (d) represent transannular $\mathrm{Zn} \cdots \mathrm{S}$ interactions.

The vast majority of the binary zinc dithiocarbamates are binuclear, adopting one of two motifs. The common feature of each motif is that there are equal numbers of chelating and bidentate bridging dithiocarbamate ligands, resulting in central, eight membered [-SCSZn $]_{2}$ rings. Transannular $\mathrm{Zn} \cdots \mathrm{S}$ interactions are noted within these rings. The differences between the motifs arise as a result of the relative disposition of the chelating ligands. In motif $\mathbf{N}$, illustrated in Figure $8 \mathrm{c}$ for $\left[\mathrm{Zn}\left(\mathrm{S}_{2} \mathrm{CNMe}_{2}\right)_{2}\right]_{2}$ (49) [76], both chelating rings are on the same side of the molecule, that is, the molecules have 2-fold or 
close to 2-fold symmetry. In motif $\mathbf{O}$, illustrated in Figure $8 \mathrm{~d}$ for $\left[\mathrm{Zn}\left(\mathrm{S}_{2} \mathrm{CNEt}_{2}\right)_{2}\right]_{2}$ (53) [79], the chelating molecules lie on opposite sides of the central ring, that is, the molecules are disposed around a centre of inversion or are close to centrosymmetric. In terms of the central [-SCSZn $]_{2}$ rings, in motif $\mathbf{N}$, they adopt a boat form, whereas in motif $\mathbf{O}$, they have the form of a chair. Of the 46 binuclear structures, four adopt motif $\mathbf{N}$ and 42 adopt motif $\mathbf{O}$.

Motif $\mathbf{N}$ is adopted by four molecules, with $\mathbf{4 9}, \mathbf{5 0}$, and $\mathbf{5 2}$ each having crystallographically-imposed 2-fold symmetry, whereas $\mathbf{5 1}$ has pseudo 2-fold symmetry only. That there is a fine balance between the symmetry in the structures conforming to motif $\mathbf{N}$ is found in the polymorphs of $\left\{\mathrm{Zn}\left(\mathrm{S}_{2} \mathrm{CN}(\mathrm{n}-\mathrm{Bu})_{2}\right]_{2}\right\}_{2}$, whereby $\mathbf{5 0}$ [77] is strictly symmetric and $\mathbf{5 1}$ [78] is not. The chelating dithiocarbamate ligands form very similar Zn-S bond lengths, with differences between them typically less than $0.1 \AA$, but those formed by the bidentate bridging ligands are even more symmetric. A common feature of each structure is the formation of transannular $\mathrm{Zn} \cdots \mathrm{S}$ interactions involving the bridging-sulphur atoms with separations normally in the range of 2.9-3.1 $\AA$. Hence, the coordination geometry is described as $S_{4}+1$. With $\tau$ [50] values between 0.39 (49) and $0.64(51)$, the resultant coordination geometries are intermediate between the ideal square-pyramidal $(\tau=0.0)$ and trigonal-bipyramidal $(\tau=1.0)$.

The majority of the binary zinc(II) dithiocarbamates adopt the binuclear motif $\mathbf{O}$, with the overwhelming majority of these molecules being disposed about a crystallographic centre of inversion. There is only one exception to this rule, whereby the binuclear molecule found in $\left\{\mathrm{Zn}\left[\mathrm{S}_{2} \mathrm{CN}(\mathrm{Me}) \mathrm{CH}_{2} \mathrm{CH}_{2} \mathrm{OH}\right]_{2}\right\}_{2}$ (76) [83] is disposed by a non-crystallographic inversion centre. This structure is a methanol solvate [83]. The same binuclear molecule is found in a di-hydrate (75) and is centrosymmetric [96]. The persistence of the centrosymmetric motif is also seen in the structures of $\left\{\mathrm{Zn}\left[\mathrm{S}_{2} \mathrm{CN}\left(\mathrm{CH}_{2} \mathrm{CH}_{2}\right)_{2} \mathrm{NPh}\right]_{2}\right\}_{2}$ (67) [92] and $\left\{\mathrm{Zn}\left[\mathrm{S}_{2} \mathrm{CN}(\mathrm{Me}) \mathrm{Et}\right]_{2}\right\}_{2}$ (70) [94] for each of which there are two crystallographically independent binuclear molecules, each disposed about a centre of inversion. The general trend in the observed $\mathrm{Zn}-\mathrm{S}$ bond lengths for structures adopting motif $\mathbf{N}$ is also found for molecules adopting motif $\mathbf{O}$, in that the bridging dithiocarbamate ligands form more symmetric $\mathrm{Zn}-\mathrm{S}$ bonds than the chelating ligands. There are two sets of solvato-polymorphs amongst the compounds adopting motif $\mathbf{O}$. The first, $\left\{\mathrm{Zn}\left[\mathrm{S}_{2} \mathrm{CN}(\mathrm{Et}) \mathrm{Ph}\right]_{2}\right\}_{2}$, is dimorphic, crystallising in monoclinic $\left(\mathrm{P} 2_{1} / \mathrm{c}\right)$ and triclinic $\left(\mathrm{P}^{-} 1\right)$ space groups, that is, 83 [101] and 84 [102], respectively. The second set of polymorphs is found for trimorphic $\left\{\mathrm{Zn}\left[\mathrm{S}_{2} \mathrm{CN}\left(\mathrm{CH}_{2} \mathrm{CH}_{2} \mathrm{OH}\right)_{2}\right]_{2}\right\}_{2}$, which crystallises in orthorhombic (Pbcn; 57) [83], monoclinic (C2/c; 58) [84], and triclinic ( $\left.\mathrm{P}^{-} 1 ; 59\right)$ [85] space groups. The molecules with motif $\mathbf{N}$ adopt $S_{4}+1$ coordination geometries that are highly distorted. Using the values of $\tau$ [50] as a measure, the coordination geometry most closely resembling an ideal square-pyramidal geometry $(\tau=0.0)$ is found in the triclinic polymorph of $\left\{\mathrm{Zn}\left[\mathrm{S}_{2} \mathrm{CN}\left(\mathrm{CH}_{2} \mathrm{CH}_{2} \mathrm{OH}\right)_{2}\right]_{2}\right\}_{2}$ (59) [85], with $\tau=0.16$, and the one with a geometry resembling a trigonal-bipyramid $(\tau=1.0)$ is found in the structure of $\left\{\mathrm{Zn}\left[\mathrm{S}_{2} \mathrm{CN}(\mathrm{Me}) \mathrm{CH}_{2}-5-1,3 \text {-benzodioxol }\right]_{2}\right\}_{2}$ (79) [74], with $\tau=0.62$.

The adoption of motif mononuclear $\mathbf{M}$ as opposed to binuclear $\mathbf{N}$ and $\mathbf{O}$ can be partially explained in terms of the steric bulk of the nitrogen-bound substituents. For example, $\mathrm{Zn}\left(\mathrm{S}_{2} \mathrm{CNCy}_{2}\right)_{2}$ (37) [25], with bulky cyclohexyl groups, is mononuclear, but when one cyclohexyl group is substituted by a smaller ethyl group to give $\left\{\mathrm{Zn}\left[\mathrm{S}_{2} \mathrm{CN}(\mathrm{Et}) \mathrm{Cy}_{2}\right\}_{2}\right.$ (82) [25], the binuclear $\mathbf{O}$ motif is formed. That other factors coming into play are evidenced by the structure of $\left\{\mathrm{Zn}\left[\mathrm{S}_{2} \mathrm{CN}(\mathrm{Me}) \mathrm{Cy}\right]_{2}\right\}_{2}$ (39) [66], where the ethyl group of $\mathbf{8 2}$ is replaced by a methyl group, as $\mathbf{3 9}$ adopts mononuclear motif, $\mathbf{M}$. This fine balance is no better exemplified by the structure of $\left\{\mathrm{Zn}\left[\mathrm{S}_{2} \mathrm{CN}(\mathrm{i}-\mathrm{Bu})_{2}\right]_{2}\right\}_{2}$ (95) [107], whereby two independent molecules comprise the crystallographic asymmetric unit, one mononuclear (motif $\mathbf{M}$ ), and the other binuclear (motif $\mathbf{O}$ ); neither molecule has crystallographic symmetry.

The five remaining structures to be described in this section carry potential nitrogen donor atoms in their nitrogen-bound substituents. In $\left\{\mathrm{Zn}\left[\mathrm{S}_{2} \mathrm{CN}\left(\mathrm{CH}_{2} \mathrm{CH}_{2}\right)_{2} \mathrm{NMe}_{2}\right\}_{\mathrm{n}}\right.$ (96) [108], one of the nitrogen atoms of the 4-methylpiperazine residue coordinates a symmetry-related zinc atom to generate a one-dimensional coordination polymer with a zig-zag topology, as illustrated in Figure 9a. The resulting $\mathrm{NS}_{4}$ donor set is intermediate between the ideal square-pyramidal $(\tau=0.0)$ and trigonal-bipyramidal $(\tau=1.0)$ coordination geometries, as seen in the value of $\tau=0.56$ [50]. 
The structure of $\mathbf{9 6}$ is assigned motif $\mathbf{P}$. Two structures, $\left\{\mathrm{Zn}\left[\mathrm{S}_{2} \mathrm{CN}(\mathrm{Benzyl}) \mathrm{CH}_{2}(3-\mathrm{py})\right]_{2}\right\}_{\mathrm{n}}$ (97) [72], Figure $9 \mathrm{~b}$, and $\left\{\mathrm{Zn}\left[\mathrm{S}_{2} \mathrm{CN}\left(\mathrm{CH}_{2} \text { ferrocenyl) } \mathrm{CH}_{2} \text { (3-py) }\right]_{2}\right\}_{\mathrm{n}}\right.$ (98) [109], adopt motif $\mathbf{Q}$, which is binuclear and located about a centre of inversion. Here, only one of the dithiocarbamate ligands employs the nitrogen atom in coordination with the second pyridyl-nitrogen atom being non-coordinating. In motif $\mathbf{Q}$, the resulting aggregate is a dimer. The $\mathrm{NS}_{4}$ donor set in $\mathbf{9 7}$ is close to a square-pyramid with $\tau=0.20$ and the nitrogen atom occupying the apical position. With a value of $\tau=0.36$, the coordination geometry in $\mathbf{9 8}$ is less regular than in $\mathbf{9 7}$. A coordination polymer with a zig-zag topology is found in the crystal of $\left\{\mathrm{Zn}\left[\mathrm{S}_{2} \mathrm{CN}(\mathrm{Et}) \mathrm{CH}_{2}(4-\mathrm{py})\right]_{2}\right\}_{n} 99$ [110] as one of the dithiocarbamate ligands is bridging in a $\mu_{2}-\kappa^{3}$ coordination mode via two sulphur atoms and the pyridyl-nitrogen atom, Figure $9 \mathrm{c}$; the other dithiocarbamate ligand for each of the two independent $\mathrm{Zn}\left[\mathrm{S}_{2} \mathrm{CN}(\mathrm{Et}) \mathrm{CH}_{2}(4-\mathrm{py})\right]_{2}$ residues is chelating. The $\mathrm{NS}_{4}$ coordination geometries are based on square-pyramidal geometries with $\tau=0.23$ and 0.32 [110]. Despite having a pyridyl- rather than an amine-nitrogen donor, the structure of $\mathbf{9 9}$ is assigned to motif $\mathbf{P}$ as for $\mathbf{9 6 .}$

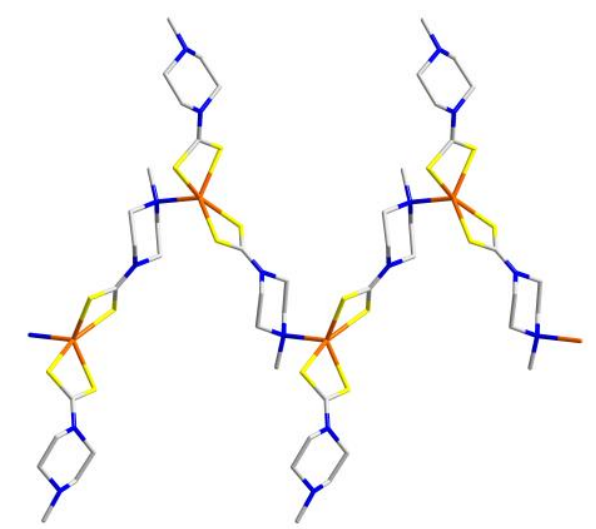

(a)

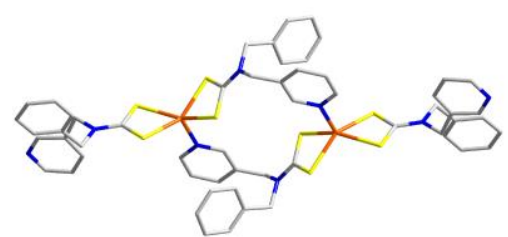

(b)

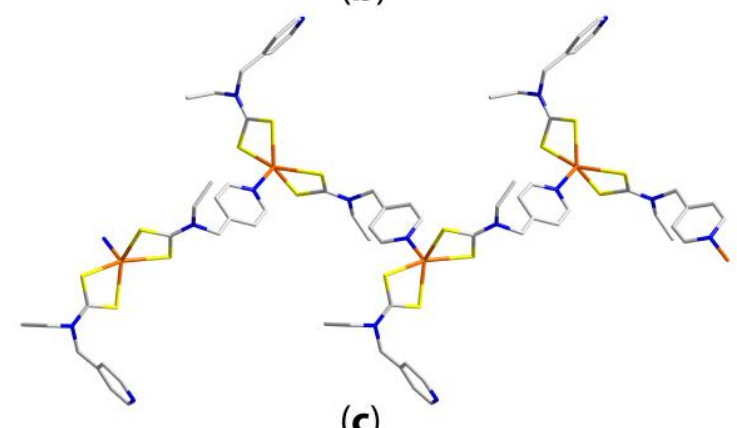

(c)

Figure 9. (a) One-dimensional coordination polymer in $\left\{\mathrm{Zn}\left[\mathrm{S}_{2} \mathrm{CN}\left(\mathrm{CH}_{2} \mathrm{CH}_{2}\right)_{2} \mathrm{NMe}\right]_{2}\right\}_{n}$ (96); (b) molecular structure of dimeric $\left\{\mathrm{Zn}\left[\mathrm{S}_{2} \mathrm{CN}(\text { Benzyl }) \mathrm{CH}_{2} \text { (3-py) }\right]_{2}\right\}_{n}$ (97); and (c) one-dimensional coordination polymer in $\left\{\mathrm{Zn}\left[\mathrm{S}_{2} \mathrm{CN}(\mathrm{Et}) \mathrm{CH}_{2}(4-\mathrm{py})\right]_{2}\right\}_{\mathrm{n}}(99)$.

The final binary zinc dithiocarbamate structure to be described, $\left\{\mathrm{Zn}\left[\mathrm{S}_{2} \mathrm{CN}\left(\mathrm{CH}_{2}\right.\right.\right.$ ferrocenyl) $\mathrm{CH}_{2}$ (4-py) $\left.]_{2}\right\}_{\mathrm{n}}$ (100) [109], also carries pyridyl-nitrogen atoms in the organic substituents and in this case, both participate in coordination to symmetry-related zinc atoms. The resulting aggregation is 
of a two-dimensional layer. As seen in the upper view of Figure 10, the layer is flat, with the ferrocenyl residues lying to either side. The $\mathrm{N}_{2} \mathrm{~S}_{4}$ donor set in motif $\mathbf{R}$ is trans-octahedral.

\subsubsection{Cadmium Dithiocarbamates}

Several of the motifs adopted by the binary cadmium(II) dithiocarbamates, 101-141 [98,111-137], are closely related to those observed for their zinc counterparts. Over and above these, are several unprecedented polymeric structures. There is a complete lack of mononuclear, tetrahedral structures (motif $\mathbf{M}$ ), reflecting the propensity of cadmium(II) to increase its coordination number. Data for the 41 known $\mathrm{Cd}\left(\mathrm{S}_{2} \mathrm{CNRR}\right)_{2}$ structures are collated in Table 4 .

Table 4. Summary of the general features of $\mathrm{Cd}\left(\mathrm{S}_{2} \mathrm{CNRR}\right)_{2}$ structures 101-141.

\begin{tabular}{|c|c|c|c|c|c|}
\hline Compound & $\mathbf{R} / \mathbf{R}^{\prime}$ & Donor set & Motif & Designation & Ref. \\
\hline 101 & $\mathrm{n}-\mathrm{Bu} / \mathrm{n}-\mathrm{Bu}$ & $\mathrm{S}_{5}$ & $\mathrm{~N}$ & dimer & [111] \\
\hline 102 & $\mathrm{Et} / \mathrm{Et}$ & $\mathrm{S}_{5}$ & $\mathrm{O}$ & dimer & {$[112,113]$} \\
\hline 103 & $\mathrm{n}-\mathrm{Pr} / \mathrm{n}-\mathrm{Pr}$ & $\mathrm{S}_{5}$ & $\mathrm{O}$ & dimer & [114] \\
\hline 104 & $\mathrm{i}-\operatorname{Pr} / \mathrm{i}-\operatorname{Pr}$ & $\mathrm{S}_{5}$ & $\mathrm{O}$ & dimer & [115] \\
\hline 105 & $\mathrm{CH}_{2} \mathrm{C}(\mathrm{H})=\mathrm{CH}_{2} / \mathrm{CH}_{2} \mathrm{C}(\mathrm{H})=\mathrm{CH}_{2}$ & $\mathrm{~S}_{5}$ & $\mathrm{O}$ & dimer & [116] \\
\hline 106 & $\mathrm{i}-\mathrm{Bu} / \mathrm{i}-\mathrm{Bu}$ & $\mathrm{S}_{5}$ & $\mathrm{O}$ & dimer & [117] \\
\hline $107^{1}$ & $\mathrm{Cy} / \mathrm{Cy}$ & $\mathrm{S}_{5}$ & $\mathrm{O}$ & dimer & [118] \\
\hline $108^{2}$ & Benzyl/Benzyl & $\mathrm{S}_{5}$ & $\mathrm{O}$ & dimer & [119] \\
\hline $109^{3}$ & Benzyl/Benzyl & $\mathrm{S}_{5}$ & $\mathrm{O}$ & dimer & [120] \\
\hline 110 & $\mathrm{CH}_{2} \mathrm{CH}_{2} \mathrm{OH} / \mathrm{CH}_{2} \mathrm{CH}_{2} \mathrm{OH}$ & $\mathrm{S}_{5}$ & $\mathrm{O}$ & dimer & [121] \\
\hline 111 & $\mathrm{R}+\mathrm{R}^{\prime}=\left(\mathrm{CH}_{2}\right)_{5}$ & $\mathrm{~S}_{5}$ & $\mathrm{O}$ & dimer & [122] \\
\hline $112^{4}$ & $\mathrm{R}+\mathrm{R}^{\prime}=\left(\mathrm{CH}_{2}\right)_{5}$ & $\mathrm{~S}_{5}$ & $\mathrm{O}$ & dimer & [123] \\
\hline 113 & $\mathrm{R}+\mathrm{R}^{\prime}=\left(\mathrm{CH}_{2}\right)_{5} \mathrm{Me}$ & $\mathrm{S}_{5}$ & $\mathrm{O}$ & dimer & [124] \\
\hline 114 & $\mathrm{R}+\mathrm{R}^{\prime}=\left(\mathrm{CH}_{2}\right)_{6}$ & $\mathrm{~S}_{5}$ & $\mathrm{O}$ & dimer & [125] \\
\hline 115 & $\mathrm{Me} / \mathrm{Ph}$ & $\mathrm{S}_{5}$ & $\mathrm{O}$ & dimer & [126] \\
\hline 116 & $\mathrm{Et} / \mathrm{Cy}$ & $\mathrm{S}_{5}$ & $\mathrm{O}$ & dimer & [118] \\
\hline 117 & $\mathrm{n}-\mathrm{Pr} / \mathrm{i}-\mathrm{Pr}$ & $\mathrm{S}_{5}$ & $\mathrm{O}$ & dimer & [127] \\
\hline $118^{5}$ & i- $\mathrm{Pr} / \mathrm{CH}_{2} \mathrm{CH}_{2} \mathrm{OH}$ & $\mathrm{S}_{5}$ & $\mathrm{O}$ & dimer & [128] \\
\hline $119^{6}$ & $\mathrm{i}-\mathrm{Pr} / \mathrm{CH}_{2} \mathrm{CH}_{2} \mathrm{OH}$ & $\mathrm{S}_{5}$ & $\mathrm{O}$ & dimer & [129] \\
\hline $120^{7}$ & $\mathrm{i}-\mathrm{Pr} / \mathrm{CH}_{2} \mathrm{CH}_{2} \mathrm{OH}$ & $\mathrm{S}_{5}$ & $\mathrm{O}$ & dimer & [129] \\
\hline 121 & Benzyl/ $\mathrm{CH}_{2}$ (2-furyl) & $\mathrm{S}_{5}$ & $\mathrm{O}$ & dimer & [130] \\
\hline 122 & Benzyl $/ \mathrm{CH}_{2} \mathrm{C}_{6} \mathrm{H}_{4}-3-\mathrm{Cl}$ & $\mathrm{S}_{5}$ & $\mathrm{O}$ & dimer & [131] \\
\hline 123 & Benzyl $/ \mathrm{CH}_{2} \mathrm{C}_{6} \mathrm{H}_{4}-4-\mathrm{Cl}$ & $\mathrm{S}_{5}$ & $\mathrm{O}$ & dimer & [73] \\
\hline 124 & $\mathrm{Me} /\left(\mathrm{CH}_{2}\right)_{3} \mathrm{NMe}_{2}$ & $\mathrm{NS}_{4}$ & Q & dimer & [132] \\
\hline 125 & $\mathrm{CH}_{2}(3-p y) / \mathrm{R}^{18}$ & $\mathrm{NS}_{4}$ & $\widehat{Q}$ & dimer & [133] \\
\hline 126 & $\mathrm{CH}_{2} \mathrm{C}_{6} \mathrm{H}_{4}-4-\mathrm{Cl} / \mathrm{CH}_{2}$ (furyl) & $2 \times S_{5}+S_{6}$ & $\mathrm{~S}$ & trimer & [131] \\
\hline 127 & $\mathrm{CH}_{2} \mathrm{C}_{6} \mathrm{H}_{4}-4-\mathrm{Me} / \mathrm{CH}_{2}$ (furyl) & $2 \times S_{5}+S_{6}$ & S & trimer & [133] \\
\hline 128 & $\mathrm{Me} /\left(\mathrm{CH}_{2}\right)_{2} \mathrm{NMe}_{2}$ & $\mathrm{NS}_{4}$ & $\mathrm{~T}$ & polymer & [134] \\
\hline $129^{9}$ & $\mathrm{Et} / \mathrm{CH}_{2}(4-\mathrm{py})$ & $\mathrm{N}_{2} \mathrm{~S}_{4}$ & $\mathrm{U}$ & double-layer & [135] \\
\hline 130 & Benzyl/CH 2 (3-py) & $\mathrm{N}_{2} \mathrm{~S}_{4}$ & $\mathrm{R}$ & layer & [133] \\
\hline 131 & $\mathrm{CH}_{2}$ (furyl) $/ \mathrm{CH}_{2}$ (3-py) & $\mathrm{N}_{2} \mathrm{~S}_{4}$ & $\mathrm{R}$ & layer & [133] \\
\hline 132 & $\mathrm{CH}_{2}$ (thiophen-2-yl)/ $\mathrm{CH}_{2}$ (3-py) & $\mathrm{N}_{2} \mathrm{~S}_{4}$ & $\mathrm{R}$ & layer & [133] \\
\hline 133 & $\mathrm{CH}_{2}$ (ferrocenyl) $/ \mathrm{CH}_{2}$ (3-py) & $\mathrm{N}_{2} \mathrm{~S}_{4}$ & $\mathrm{R}$ & layer & [109] \\
\hline 134 & $\mathrm{CH}_{2}\left(3-\right.$-py) $/ \mathrm{CH}_{2}$ (3-py) & $\mathrm{N}_{2} \mathrm{~S}_{4}$ & $\mathrm{R}$ & layer & [133] \\
\hline 135 & $\mathrm{Me} / \mathrm{Me}$ & $\mathrm{S}_{6}$ & $\mathrm{~V}$ & polymer & [136] \\
\hline $136^{10}$ & $\mathrm{i}-\mathrm{Pr} / \mathrm{CH}_{2} \mathrm{CH}_{2} \mathrm{OH}$ & $\mathrm{S}_{6}$ & $\mathrm{~V}$ & polymer & [129] \\
\hline 137 & Benzyl/ $\mathrm{R}^{211}$ & $\mathrm{~S}_{6}$ & $\mathrm{~V}$ & polymer & [131] \\
\hline 138 & $\mathrm{CH}_{2}$ (furyl) $/ \mathrm{CH}_{2} \mathrm{C}_{6} \mathrm{H}_{4}-4-\mathrm{F}$ & $\mathrm{S}_{6}$ & $\mathrm{~V}$ & polymer & [131] \\
\hline 139 & $\mathrm{CH}_{2}$ (furyl) $/ \mathrm{CH}_{2} \mathrm{C}_{6} \mathrm{H}_{4}-4-\mathrm{NO}_{2}$ & $\mathrm{~S}_{6}$ & $\mathrm{~V}$ & polymer & [131] \\
\hline 140 & $\mathrm{Me} / \mathrm{CH}_{2} \mathrm{C}(\mathrm{H})(\mathrm{OMe})_{2}$ & $\mathrm{~S}_{6}$ & W & polymer & [98] \\
\hline $141^{12}$ & $\mathrm{i}-\mathrm{Pr} / \mathrm{CH}_{2} \mathrm{CH}_{2} \mathrm{OH}$ & $\mathrm{S}_{6}$ & $\mathrm{~W}$ & polymer & [128] \\
\hline
\end{tabular}

${ }^{1}$ di-dichloromethane solvate; ${ }^{2} \mathrm{P} 2{ }_{1} / \mathrm{n}$ polymorph; ${ }^{3} \mathrm{P}^{-1}$ polymorph; ${ }^{4}$ mono-benzene solvate; ${ }^{5}$ di-ethanol solvate; ${ }^{6}$ di-acetonitrile solvate di-hydrate; ${ }^{7} 1: 2$ co-crystal with 3 -isopropyl-1,3-oxazolidine- 2 -thione; ${ }^{8} \mathrm{R}^{1}$ is $1 \mathrm{H}$-indol-3-ylmethyl; ${ }^{9}$ 3-methylpyridine solvate; ${ }^{10}$ ethanol hemi-solvate; ${ }^{11} \mathrm{R}^{2}$ is 1 ,3-benzodioxol-5- $\mathrm{CH}_{2} ;{ }^{12}{ }^{1} / 3$ acetonitrile solvate. 


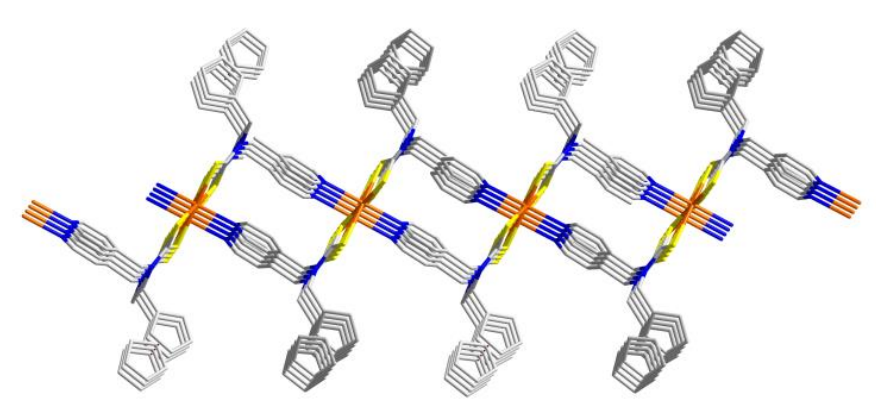

(a)

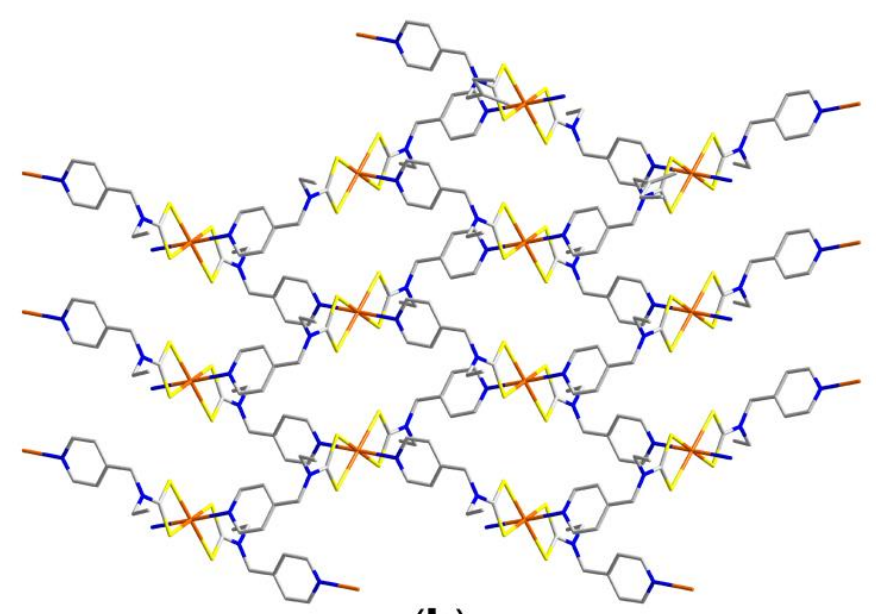

(b)

Figure 10. Two views (a) side-on and (b) perpendicular to the two-dimensional layer in the structure of $\left\{\mathrm{Zn}\left[\mathrm{S}_{2} \mathrm{CN}\left(\mathrm{CH}_{2} \text { ferrocenyl }\right) \mathrm{CH}_{2}(4-\mathrm{py})\right]_{2}\right\}_{n}(\mathbf{1 0 0})$.

There is a sole example of a cadmium dithiocarbamate adopting motif $\mathbf{N}$, that is, a 2 -fold symmetric, binuclear structure with equal numbers of chelating and bridging dithiocarbamate ligands. This structure, $\left\{\mathrm{Cd}\left[\mathrm{S}_{2} \mathrm{CN}(\mathrm{n}-\mathrm{Bu})_{2}\right]_{2}\right\}_{2}$ (101) [111], Figure 11a, exhibits a very narrow range of $\mathrm{Cd}-\mathrm{S}$ bond lengths, 2.55 and $2.59 \AA$ for the chelating ligand and 2.51 and $2.61 \AA$ for the bridging ligand. The transannular Cd-S interaction is considerably shorter at $2.89 \AA$ than the equivalent interaction observed for the zinc analogues and therefore, the cadmium centre can be considered as five-coordinate. The $S_{5}$ donor set, with a value of $\tau=0.50$, is exactly intermediate between ideal square-pyramidal $(\tau=0.0)$ and trigonal-pyramidal $(\tau=1.0)$ geometries [50].

A considerably larger number of binuclear $\left[\mathrm{Cd}\left(\mathrm{S}_{2} \mathrm{CNRR}\right)_{2}\right]_{2}$ structures, that is, 22, adopt the centrosymmetric analogue of motif $\mathbf{N}$, that is, motif $\mathbf{O}$, with archetypical $\left[\mathrm{Cd}\left(\mathrm{S}_{2} \mathrm{CNEt}_{2}\right)_{2}\right]_{2}$ (102) $[112,113]$ shown in Figure 11b. In most structures, the range of chelating and bridging $\mathrm{Cd}-\mathrm{S}$ bond lengths is quite narrow, with the narrowest range of 2.58 to $2.59 \AA$ being found in $\left\{\mathrm{Cd}\left[\mathrm{S}_{2} \mathrm{CN}\left(\mathrm{CH}_{2}\right)_{5}-4-\mathrm{Me}\right]\right\}_{2}$ (113) [124]. There is only one exceptional structure where the Cd-S bond lengths span a considerably greater range, that is, in $\left\{\mathrm{Cd}\left[\mathrm{S}_{2} \mathrm{CN}(\mathrm{i}-\mathrm{Pr}) \mathrm{CH}_{2} \mathrm{CH}_{2} \mathrm{OH}\right]_{2}\right\}_{2}$ (120), isolated in a 1:2 co-crystal with 3-isopropyl-1,3-oxazolidine-2-thione [129], where the Cd-S bond lengths span a range of about $0.30 \AA$, that is, with bridging Cd-S bond lengths of 2.42 and $2.56 \AA$, and chelating bonds of 2.51 and $2.71 \AA$. The latter structure also presents the longest transannular contact of $3.05 \AA$. In the rest of the structures, these interactions are usually less than $2.85 \AA$, and as short as $2.74 \AA$, as in $\left\{\mathrm{Cd}\left[\mathrm{S}_{2} \mathrm{CN}(\mathrm{i}-\mathrm{Pr}) \mathrm{CH}_{2} \mathrm{CH}_{2} \mathrm{OH}\right]_{2}\right\}_{2}$ (119) [129], isolated as a di-acetonitrile solvate, di-hydrate. The coordination geometries tend to be closer to square-pyramidal for the molecules in this category. The most extreme coordination geometry is found in $\left\{\mathrm{Cd}\left[\mathrm{S}_{2} \mathrm{CN}\left(\text { Benzyl) } \mathrm{CH}_{2} \text { (2-furyl) }\right]_{2}\right\}_{2}\right.$ (121) [130] with $\tau=0.0$, with the bridging-sulphur atom occupying the apical position. Only three of the molecules have values of $\tau>0.50$, for example, $\left\{\mathrm{Cd}\left[\mathrm{S}_{2} \mathrm{CN}(\mathrm{n}-\mathrm{Pr})-\mathrm{i}-\mathrm{Pr}\right]_{2}\right\}_{2}(\mathbf{1 1 7})[127](\tau=0.51)$ and 
$\left\{\mathrm{Cd}\left[\mathrm{S}_{2} \mathrm{CN}(\mathrm{n}-\mathrm{Pr}) \mathrm{CH}_{2} \mathrm{C}_{6} \mathrm{H}_{4}-3-\mathrm{Cl}_{2}\right\}_{2}\right.$ (122) [131] $(\tau=0.62)$. The third structure, $\left\{\mathrm{Cd}\left[\mathrm{S}_{2} \mathrm{CN}\left(\mathrm{CH}_{2}\right)_{5}\right]_{2}\right\}_{2}$ (111) [122], has two independent molecules in the crystallographic asymmetric unit, with one of the molecules having $\tau=0.54$ and the other having $\tau=0.39$. The $\left\{\mathrm{Cd}\left[\mathrm{S}_{2} \mathrm{CN}(\text { Benzyl })_{2}\right]_{2}\right\}_{2}$ compound has been characterised in two polymorphs. In the triclinic form, 108 [119], $\tau=0.54$, and in the monoclinic form, 109 [120], with two independent molecules in the asymmetric unit, the values of $\tau$ compute to 0.01 and 0.42 .

The flexibility in the $\left[\mathrm{Cd}\left(\mathrm{S}_{2} \mathrm{CNRR}^{\prime}\right)_{2}\right]_{2}$ molecules adopting motif $\mathbf{O}$ is clearly appreciated when one compares the pairs of structures 108 and 109 (coordination geometries), and 118 and 119 (Cd-S bond lengths).

Two molecules, that is, $\left\{\mathrm{Cd}\left[\mathrm{S}_{2} \mathrm{CN}(\mathrm{Me})\left(\mathrm{CH}_{2}\right)_{3} \mathrm{NMe}_{2}\right]_{2}\right\}_{2}$ (124) [134], Figure 11c, and $\left\{\mathrm{Cd}\left[\mathrm{S}_{2} \mathrm{CNCH}_{2}\right.\right.$ (3-py)(1H-indol-3-ylmethyl) $\left.]_{2}\right\}_{2}$ (125) [133], adopt binuclear motif $\mathbf{Q}$ owing to the coordination of a nitrogen atom of an organic substituent to a symmetry related cadmium atom; both binuclear species are centrosymmetric. The five-coordinate indicator, $\tau$, is 0.22 for 124 with the nitrogen atom in the apical position, and 0.42 for 125 , indicating a more distorted geometry.

A new motif, trinuclear motif $\mathbf{S}$, is found in two structures, namely $\left\{\mathrm{Cd}\left[\mathrm{S}_{2} \mathrm{CN}\left(\mathrm{CH}_{2} \mathrm{C}_{6} \mathrm{H}_{4}-4-\mathrm{X}\right)\right.\right.$ $\mathrm{CH}_{2}$ (furyl) $\left.]_{2}\right\}_{3}$, for isostructural $\mathrm{X}=\mathrm{Me}$ (126) [131] and $\mathrm{X}=\mathrm{Cl}$ (127) [133], Figure 11d. The motif sees a central $\mathrm{Cd}$ (dithiocarbamate) ${ }_{2}$ residue associated with two other residues so that the cadmium atoms in the outer molecules have $S_{5}$ coordination geometries, resembling the situation in motif $\mathbf{O}$. By contrast, the central cadmium atom is six-coordinate within a $S_{6}$ donor set; each trinuclear molecule is located on a centre of inversion. In 126, the range of Cd-S bond lengths for the five-coordinate cadmium atom is 2.55 to $2.65 \AA$ with the transannular distance being $2.71 \AA$, and the value of $\tau$ is 0.30. The Cd-S bond lengths for the central cadmium span a wider range, that is, 2.59 to $2.89 \AA$. The equivalent parameters in $\mathbf{1 2 7}$ present very similar features and the same value for $\tau$.

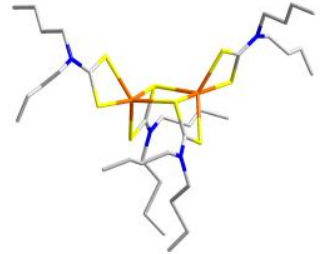

(a)

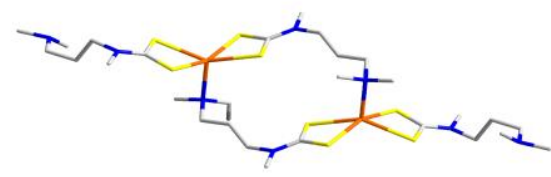

(c)

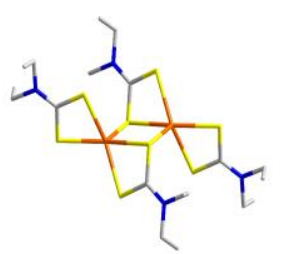

(b)

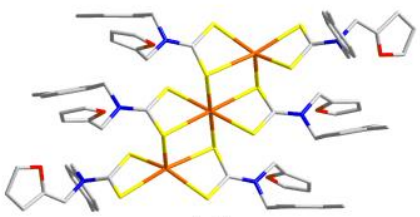

(d)

Figure 11. Molecular structures of (a) dimeric (2-fold symmetry) $\left\{\mathrm{Cd}\left[\mathrm{S}_{2} \mathrm{CN}(\mathrm{n}-\mathrm{Bu})_{2}\right]_{2}\right\}_{2}$ (101), (b) dimeric (inversion symmetry) $\left\{\mathrm{Cd}\left[\mathrm{S}_{2} \mathrm{CN}(\mathrm{n}-\mathrm{Bu})_{2}\right]_{2}\right\}_{2}$ (102), (c) dimeric $\left\{\mathrm{Cd}\left[\mathrm{S}_{2} \mathrm{CN}(\mathrm{Me})\left(\mathrm{CH}_{2}\right)_{3} \mathrm{NMe}_{2}\right]_{2}\right\}_{2}(\mathbf{1 2 4})$, and (d) trimeric $\left\{\mathrm{Cd}\left[\mathrm{S}_{2} \mathrm{CN}\left(\mathrm{CH}_{2} \mathrm{C}_{6} \mathrm{H}_{4}-4-\mathrm{Me}\right) \mathrm{CH}_{2} \text { (furyl) }\right]_{2}\right\}_{3}$ (127).

The remaining binary cadmium dithiocarbamate structures are polymeric owing to coordination by amine- or pyridyl-nitrogen atoms or by bridging dithiocarbamate ligands. In $\left\{\mathrm{Cd}\left[\mathrm{S}_{2} \mathrm{CN}(\mathrm{Me})\right.\right.$ $\left.\left.\left(\mathrm{CH}_{2}\right)_{2} \mathrm{NMe}_{2}\right]_{2}\right\}_{\mathrm{n}}$ (128) [134], a one-dimensional array is formed as a result of the coordination of an amine-nitrogen atom to a symmetry-related cadmium atom, Figure 12a. This chain resembles motif $\mathbf{P}$, except that the topology in $\mathbf{1 2 8}$ is helical so it is assigned as motif $\mathbf{T}$. The $\mathrm{NS}_{4}$ donor set is almost perfectly between the ideal square-pyramidal $(t=0.0)$ and trigonal-bipyramidal $(\tau=1.0)$, having a value of $\tau=0.53$ [50]. A new motif, motif $\mathbf{U}$, is found in the crystal of $\left\{\mathrm{Cd}\left[\mathrm{S}_{2} \mathrm{CN}(\mathrm{Et}) \mathrm{CH}_{2}(4 \mathrm{py})\right]_{2}\right\}_{\mathrm{n}}$ (129) [135]. Here, both dithiocarbamate ligands are S,S-chelating one cadmium atom and at the same bridging different cadmium atoms so as to form a double-layer, Figure 12b. This arrangement defines square 
channels in which solvent 3-methylpyridine molecules reside (not shown). The resultant $\mathrm{N}_{2} \mathrm{~S}_{4}$ donor set is based on an octahedron and, crucially, the nitrogen donors occupy mutually cis-positions. In a clear difference, the remaining five structures with potential pyridyl-nitrogen atoms feature trans- $\mathrm{N}_{2} \mathrm{~S}_{4}$ donor sets. This arrangement allows for the formation of two-dimensional arrays reminiscent of motif $\mathbf{R}$, and an exemplar, $\left.\mathrm{Cd}\left[\mathrm{S}_{2} \mathrm{CN}(\mathrm{Benzyl}) \mathrm{CH}_{2}(3-\mathrm{py})\right]_{2}\right\}_{\mathrm{n}}(\mathbf{1 3 0})$ [133], is illustrated in Figure 12c.

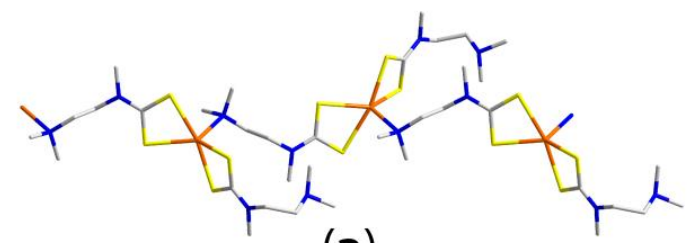

(a)

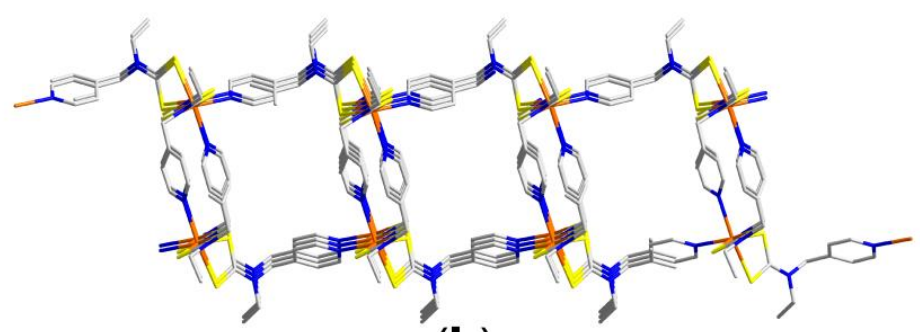

(b)

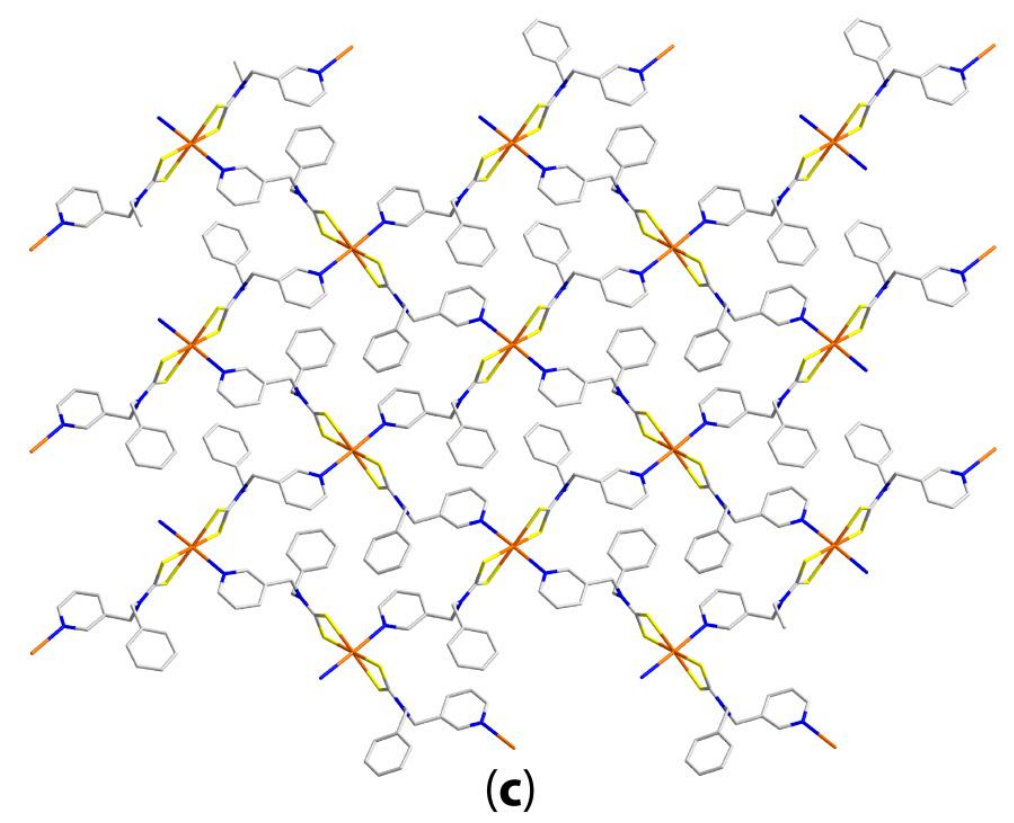

Figure 12. Images of (a) one-dimensional $\left\{\mathrm{Cd}\left[\mathrm{S}_{2} \mathrm{CN}(\mathrm{Me})\left(\mathrm{CH}_{2}\right)_{2} \mathrm{NMe}_{2}\right]_{2}\right\}_{\mathrm{n}}(\mathbf{1 2 8})$; (b) the double-layer in $\left\{\mathrm{Cd}\left[\mathrm{S}_{2} \mathrm{CN}(\mathrm{Et}) \mathrm{CH}_{2}(3-\mathrm{py})\right]_{2}\right\}_{n}$ (129); and (c) two-dimensional $\left\{\mathrm{Cd}\left[\mathrm{S}_{2} \mathrm{CN}(\text { Benzyl }) \mathrm{CH}_{2}(3-\mathrm{py})\right]_{2}\right\}_{\mathrm{n}}(\mathbf{1 3 0})$.

The distinctive feature in the seven crystals of $\mathbf{1 3 5}-\mathbf{1 4 1}[98,128,129,131,136]$ is that each of the dithiocarbamate ligands adopts a $\mu_{2} \mathrm{~K}^{3}$-coordination mode, leading to octahedral $\mathrm{S}_{6}$ coordination geometries and one-dimensional chains. Five of the structures feature 2-fold symmetry with the cadmium atom located on the axis, whereas the chains are propagated by crystallographic inversion symmetry in the remaining two structures. Two views of the chain for $\left[\mathrm{Cd}\left(\mathrm{S}_{2} \mathrm{CNMe}\right)_{2}\right]_{\mathrm{n}}$ (135) [136], being an exemplar for motif $\mathbf{V}$, are shown in Figure 13a, and equivalent views for $\left\{\mathrm{Cd}\left[\mathrm{S}_{2} \mathrm{CN}(\mathrm{i}-\mathrm{Pr}) \mathrm{CH}_{2} \mathrm{CH}_{2} \mathrm{OH}\right]_{2}\right\}_{n}$ (141) [128], motif $\mathbf{W}$, are shown in Figure 13b. The key difference between the chains, both of which have twisted topologies, is found in the orientation of the nitrogen-bound substituents, which are directed in the same direction in motif $\mathbf{V}$, reflecting the 
2-fold symmetry, but in different directions for motif $\mathbf{W}$, this time reflecting the inversion symmetry. The chains found in $\mathbf{1 3 6}$ [129] and $\mathbf{1 4 1}$ [128], that is, adopting motifs $\mathbf{S}$ and T, respectively, are supramolecular isomers [137], suggesting relatively small energy differences between the motifs. Further, solutions of each of $\mathbf{1 3 6}$ and $\mathbf{1 4 1}$ converted over time, within hours, into the dimeric motif $\mathbf{O}$, that is, into 118 [128] and $\mathbf{1 1 9}$ [129], respectively, are consistent with the notion that the commonly observed binuclear motif is the thermodynamic outcome of the crystallisation of these compounds.
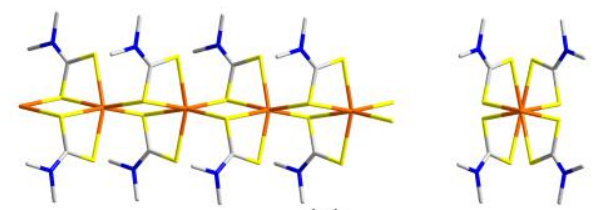

(a)

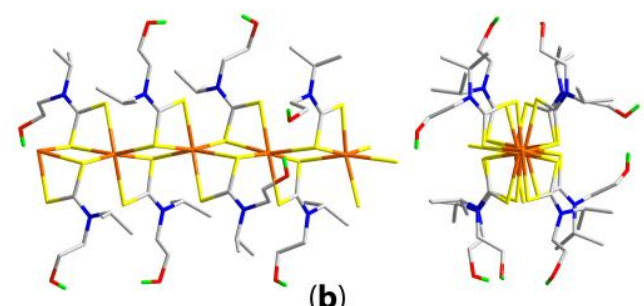

Figure 13. Side- and end-on views of one-dimensional chains in the crystals of $(\mathbf{a})\left[\mathrm{Cd}\left(\mathrm{S}_{2} \mathrm{CNMe}\right)_{2}\right]_{\mathrm{n}}$ (135) and (b) $\left\{\mathrm{Cd}\left[\mathrm{S}_{2} \mathrm{CN}(\mathrm{i}-\mathrm{Pr}) \mathrm{CH}_{2} \mathrm{CH}_{2} \mathrm{OH}\right]_{2}\right\}_{n}$ (141). Additional colour code: hydrogen, green.

\subsubsection{Mercury Dithiocarbamates}

Unlike the foregoing binary zinc(II) and cadmium(II) dithiocarbamates, the structural chemistry of the mercury(II) analogues features quite extensive supramolecular association based on secondary $\mathrm{Hg} \cdots \mathrm{S}$ interactions [138]. Key geometric data for the $44 \mathrm{Hg}\left(\mathrm{S}_{2} \mathrm{CNRR}^{\prime}\right)_{2}$ structures, 142-185 [39,70,101,105,139-163], described in this section are listed in Table 5. The exceptional series of structures, at least in terms of forming intermolecular $\mathrm{Hg} \cdots \mathrm{S}$ interactions, are strictly monomeric 142-145 [139-142], illustrated for $\mathrm{Hg}\left[\mathrm{S}_{2} \mathrm{CN}(\mathrm{i}-\mathrm{Pr})_{2}\right]_{2}$ (142) [139] in Figure 14a, as there are no intermolecular $\mathrm{Hg} \cdots \mathrm{S}$ contacts less than $4.0 \AA$ in their respective crystals. Each of the four structures has the mercury atom lying as a 2-fold axis of symmetry and conforms to motif $\mathbf{M}$, that is, distorted tetrahedral geometry within an $\mathrm{S}_{4}$ donor set. $\mathrm{In} \mathrm{Hg}\left(\mathrm{S}_{2} \mathrm{CNCy}_{2}\right)_{2}$ (143) [140], the dithiocarbamate ligand chelates the mercury centre with symmetric Hg-S bond lengths of 2.53 and $2.54 \AA$, and the widest S-Hg-S angle is $142^{\circ}$. At the other extreme, for $\mathrm{Hg}\left(\mathrm{S}_{2} \mathrm{CNBenzyl}_{2}\right)_{2}$ (144) [141], the dithiocarbamate ligand coordinates with asymmetric Hg-S bond lengths of 2.40 and $2.79 \AA$, and with the widest angle of $160^{\circ}$ formed between the more tightly bound sulphur atoms.

Compounds 146-155 [39,70,101,105,143-147] also adopt motif $\mathbf{M}$, but lack the symmetry exhibited by $\mathbf{1 4 2 - 1 4 5 . ~ T h e ~ d i t h i o c a r b a m a t e ~ l i g a n d s ~ g e n e r a l l y ~ c o o r d i n a t e ~ w i t h ~ d i s p a r a t e ~ H g - S ~}$ bond lengths, with the differences between the short and long bonds usually being 0.3-0.4 $\AA$. Supramolecular molecular association between centrosymmetrically-related molecules is always found in 146-155, with intermolecular $\mathrm{Hg} \cdots \mathrm{S}$ separations ranging from a short $3.18 \AA$ in $\mathrm{Hg}\left[\mathrm{S}_{2} \mathrm{CN}\right.$ $\left(\mathrm{CH}_{2} \mathrm{CH}_{2} \mathrm{OH}\right) \mathrm{CH}_{2}$ (ferrocenyl) $]_{2}$ (155) [70] to a long $3.85 \AA$ in $\mathrm{Hg}\left[\mathrm{S}_{2} \mathrm{CN}\left(\right.\right.$ Benzyl) $\mathrm{CH}_{2}(1-\mathrm{Me}-1 \mathrm{H}-$ pyrrol-2-yl)] (152) [146], much in the same way as discussed above for the transition of zinc dithiocarbamates between motifs $\mathbf{M}$ and $\mathbf{O}$, see Figure 8. For mercury and sulphur, the sum of the van der Waals radii is assumed to be $3.35 \AA$ [20]. An exemplar for the tendency towards dimerization in the mercury dithiocarbamates is shown in Figure $14 \mathrm{~b}$ for $\mathrm{Hg}\left[\mathrm{S}_{2} \mathrm{CN}\left(\mathrm{CH}_{2}\right)_{4} \mathrm{NCH}_{2} \mathrm{C}(\mathrm{H})=\mathrm{C}(\mathrm{H}) \mathrm{Ph}\right]$ (147) [144].

Mononuclear motifs are also found for 156-160 [72,148-151], with the major difference being that the $\mathrm{S}_{4}$ donor set is strictly square-planar, with the mercury atom located on a crystallographic centre of inversion in all cases except for $\mathrm{Hg}\left[\mathrm{S}_{2} \mathrm{CN}\left(\mathrm{CH}_{2} \mathrm{CH}_{2} \mathrm{OH}\right)_{2}\right]_{2}$ (160) [151]. Accordingly, this 
series is assigned motif $\mathbf{U}$. The dithiocarbamate ligands for motif $\mathbf{U}$ coordinate in an asymmetric mode, with the differences between long and short Hg-S bonds being around $0.6 \AA$; this contrasts with the symmetric square-planar geometries observed for motif $\mathbf{D}$. The widest angle in the square-plane is $180^{\circ}$ for all structures adopting motif $\mathbf{X}$, including for non-symmetric $\mathrm{Hg}\left[\mathrm{S}_{2} \mathrm{CN}\left(\mathrm{CH}_{2} \mathrm{CH}_{2} \mathrm{OH}\right)_{2}\right]_{2}$ (160) [151]. The alteration in geometry and increased asymmetry in the Hg-S bond lengths correlates with the formation of two intermolecular $\mathrm{Hg}$...S interactions, leading to linear supramolecular chains in the respective crystals. The $\mathrm{Hg} \cdots \mathrm{S}$ separations range from $3.18 \AA$ for one of the contacts in $\mathrm{Hg}\left[\mathrm{S}_{2} \mathrm{CN}\left(\mathrm{CH}_{2} \mathrm{CH}_{2} \mathrm{OH}\right)_{2}\right]_{2}$ (160) [151] to $3.40 \AA$ in $\mathrm{Hg}\left(\mathrm{S}_{2} \mathrm{CNMe}\right)_{2}$ (156) [148]. This supramolecular association is shown in Figure $14 \mathrm{c}$ for $\mathrm{Hg}\left(\mathrm{S}_{2} \mathrm{CNEt}_{2}\right)_{2}$ (157) [150]. The extended coordination geometry is $S_{4}+S_{2}$, with the weakly associated sulphur atoms mutually trans.

Table 5. Summary of the general features of $\mathrm{Hg}\left(\mathrm{S}_{2} \mathrm{CNRR}^{\prime}\right)_{2}$ structures 142-185.

\begin{tabular}{|c|c|c|c|c|c|}
\hline Compound & $\mathbf{R} / \mathbf{R}^{\prime}$ & Donor Set & Motif & Designation & Ref. \\
\hline 142 & $\mathrm{i}-\operatorname{Pr} / \mathrm{i}-\operatorname{Pr}$ & $\mathrm{S}_{4}$ & M & monomer & [139] \\
\hline 143 & Су/Сy & $\mathrm{S}_{4}$ & M & monomer & [140] \\
\hline 144 & Benzyl/Benzyl & $\mathrm{S}_{4}$ & M & monomer & [141] \\
\hline 145 & $\mathrm{R}+\mathrm{R}^{\prime}=\left(\mathrm{CH}_{2}\right)_{4}$ & $\mathrm{~S}_{4}$ & M & monomer & [142] \\
\hline 146 & $\mathrm{i}-\mathrm{Bu} / \mathrm{i}-\mathrm{Bu}$ & $\mathrm{S}_{4}$ & K & monomer & [143] \\
\hline 147 & $\mathrm{R}+\mathrm{R}^{\prime}=\left(\mathrm{CH}_{2}\right)_{4} \mathrm{NCH}_{2} \mathrm{C}(\mathrm{H})=\mathrm{C}(\mathrm{H}) \mathrm{Ph}$ & $\mathrm{S}_{4}$ & M & monomer & [144] \\
\hline 148 & $\mathrm{~N}\left(\mathrm{RR}^{\prime}\right)=\mathrm{R}^{11}$ & $\mathrm{~S}_{4}$ & M & monomer & [145] \\
\hline $149^{2}$ & $\mathrm{Et} / \mathrm{Ph}$ & $\mathrm{S}_{4}$ & M & monomer & [101] \\
\hline 150 & $\mathrm{i}-\operatorname{Pr} / \mathrm{Cy}$ & $\mathrm{S}_{4}$ & M & monomer & [143] \\
\hline $151^{3}$ & $\mathrm{Me} / \mathrm{Ph} ; \mathrm{n}-\mathrm{Bu} / \mathrm{Ph}$ & $\mathrm{S}_{4}$ & M & monomer & [105] \\
\hline 152 & Benzyl/ $\mathrm{CH}_{2}$ (1-Me-1H-pyrrol-2-yl) & $\mathrm{S}_{4}$ & M & monomer & [146] \\
\hline 153 & Benzyl $/ \mathrm{CH}_{2}$ (ferrocenyl) & $\mathrm{S}_{4}$ & M & monomer & [147] \\
\hline 154 & $\mathrm{CH}_{2}(3-p y) / \mathrm{CH}_{2}(1-\mathrm{Me}-1 \mathrm{H}$-pyrrol-2-yl) & $\mathrm{S}_{4}$ & M & monomer & [39] \\
\hline 155 & $\mathrm{CH}_{2} \mathrm{CH}_{2} \mathrm{OH} / \mathrm{CH}_{2}$ (ferrocenyl) & $\mathrm{S}_{4}$ & M & monomer & {$[70]$} \\
\hline 156 & $\mathrm{Me} / \mathrm{Me}$ & $\mathrm{S}_{4}$ & $x$ & monomer & [148] \\
\hline 157 & $\mathrm{Et} / \mathrm{Et}$ & $\mathrm{S}_{4}$ & $x$ & monomer & [149] \\
\hline 158 & Benzyl/ $\mathrm{CH}_{2}$ (3-py) & $\mathrm{S}_{4}$ & $X$ & monomer & {$[72]$} \\
\hline 159 & Benzyl $/ \mathrm{CH}_{2}(4-p y)$ & $\mathrm{S}_{4}$ & $x$ & monomer & [150] \\
\hline 160 & $\mathrm{CH}_{2} \mathrm{CH}_{2} \mathrm{OH} / \mathrm{CH}_{2} \mathrm{CH}_{2} \mathrm{OH}$ & $\mathrm{S}_{4}$ & $x$ & monomer & [151] \\
\hline 161 & n-Bu/CH ${ }_{2}(1 \mathrm{H}-p y r r o l-2-y l)$ & $\mathrm{S}_{4}$ & $\mathrm{Y}$ & monomer & [152] \\
\hline 162 & $\mathrm{CH}_{2}$ (4-py)/ $\mathrm{CH}_{2}$ (1H-pyrrol-2-yl) & $\mathrm{S}_{4}$ & $\mathrm{Z}$ & monomer & [146] \\
\hline 163 & $\mathrm{Et} / \mathrm{Et}$ & $\mathrm{S}_{4}+1$ & $\mathrm{O}$ & dimer & {$[149,153]$} \\
\hline 164 & i-Pr/i-Pr & $\mathrm{S}_{4}+1$ & $\mathrm{O}$ & dimer & [154] \\
\hline 165 & $\mathrm{n}-\mathrm{Bu} / \mathrm{n}-\mathrm{Bu}$ & $\mathrm{S}_{4}+1$ & $\mathrm{~N}$ & dimer & [143] \\
\hline 166 & $\mathrm{R}+\mathrm{R}^{\prime}=\left(\mathrm{CH}_{2}\right)_{4}$ & $\mathrm{~S}_{4}+1$ & $\mathrm{O}$ & dimer & [155] \\
\hline 167 & $\mathrm{R}+\mathrm{R}^{\prime}=\left(\mathrm{CH}_{2}\right)_{5} \mathrm{Me}$ & $\mathrm{S}_{4}+1$ & $\mathrm{O}$ & dimer & [156] \\
\hline 168 & $\mathrm{R}+\mathrm{R}^{\prime}=\left(\mathrm{CH}_{2}\right)_{6}$ & $\mathrm{~S}_{4}+1$ & $\mathrm{O}$ & dimer & [157] \\
\hline 169 & $\mathrm{CH}_{2}$ (2-furyl) $/ \mathrm{CH}_{2}$ (2-furyl) & $\mathrm{S}_{4}+1$ & $\mathrm{O}$ & dimer & [158] \\
\hline 170 & $\mathrm{Me} / \mathrm{Ph}$ & $\mathrm{S}_{4}+1$ & $\mathrm{O}$ & dimer & [159] \\
\hline 171 & $\mathrm{Me} /\left(\mathrm{CH}_{2}\right)_{2} \mathrm{Ph}$ & $\mathrm{S}_{4}+1$ & $\mathrm{O}$ & dimer & [160] \\
\hline 172 & $\mathrm{Et} / \mathrm{Cy}$ & $\mathrm{S}_{4}+1$ & $\mathrm{O}$ & dimer & [143] \\
\hline 173 & $\mathrm{Et} / \mathrm{Ph}$ & $\mathrm{S}_{4}+1$ & $\mathrm{O}$ & dimer & [161] \\
\hline 174 & $\mathrm{i}-\mathrm{Pr} / \mathrm{CH}_{2} \mathrm{CH}_{2} \mathrm{OH}$ & $\mathrm{S}_{4}+1$ & $\mathrm{O}$ & dimer & [162] \\
\hline 175 & Benzyl/ $\mathrm{CH}_{2}$ (2-furyl) & $\mathrm{S}_{4}+1$ & $\mathrm{O}$ & dimer & [158] \\
\hline 176 & $\left(\mathrm{CH}_{2}\right)_{2} \mathrm{Ph} / \mathrm{CH}_{2}$ (2-furyl) & $\mathrm{S}_{4}+1$ & $\mathrm{O}$ & dimer & [163] \\
\hline 177 & $\left(\mathrm{CH}_{2}\right)_{2} \mathrm{Ph} / \mathrm{CH}_{2} \mathrm{CH}_{2}$ (thiophen-2-yl) & $\mathrm{S}_{4}+1$ & $\mathrm{O}$ & dimer & [163] \\
\hline 178 & $\mathrm{CH}_{2}\left(3-\right.$ py) $/ \mathrm{CH}_{2}$ (ferrocenyl) & $\mathrm{S}_{4}+1$ & $\mathrm{O}$ & dimer & [109] \\
\hline $179^{3}$ & $\mathrm{CH}_{2}$ (3-py) $/ \mathrm{CH}_{2}$ (1-naphthyl) & $\mathrm{NS}_{4}$ & $\mathrm{Q}$ & dimer & [39] \\
\hline $180^{4}$ & $\mathrm{NRR}^{\prime}=\mathrm{R}^{25}$ & $2 \times S_{5}+S_{6}$ & $\mathrm{~S}$ & trimer & [145] \\
\hline 181 & $\mathrm{Me} / \mathrm{CH}_{2}(4-p y)$ & $\mathrm{NS}_{4}$ & $\mathrm{Z}$ & polymer & [72] \\
\hline 182 & $\mathrm{CH}_{2}$ (3-py) $/ \mathrm{CH}_{2}(1,3$-benzodioxo-5-yl) & $\mathrm{NS}_{4}$ & $\mathrm{P}$ & polymer & [72] \\
\hline 183 & $\mathrm{CH}_{2}\left(4-\right.$-py) $/ \mathrm{CH}_{2}$ (2-furyl) & $\mathrm{N}_{2} \mathrm{~S}_{4}$ & $\mathrm{R}$ & layer & [72] \\
\hline 184 & $\left(\mathrm{CH}_{2}\right)_{2} \mathrm{Ph} / \mathrm{CH}_{2}(3-$-py $)$ & $\mathrm{NS}_{5}$ & AA & polymer & [72] \\
\hline 185 & $\left(\mathrm{CH}_{2}\right)_{2} \mathrm{Ph} / \mathrm{CH}_{143}(1 \mathrm{H}-$ pyrrol-2-yl) & $\mathrm{S}_{6}$ & $\mathrm{~V}$ & polymer & [152] \\
\hline
\end{tabular}

${ }^{1} \mathrm{R}^{1}$ is 3,4-dihydroquinoline- $1(2 \mathrm{H}) ;{ }^{2}$ tolyl hemi-solvate; ${ }^{3}$ mono-ethanol solvate; ${ }^{4}$ mono-pyridine solvate; ${ }^{5} \mathrm{R}^{2}$ is 1,2,3,4-tetrahydroquinoline. 

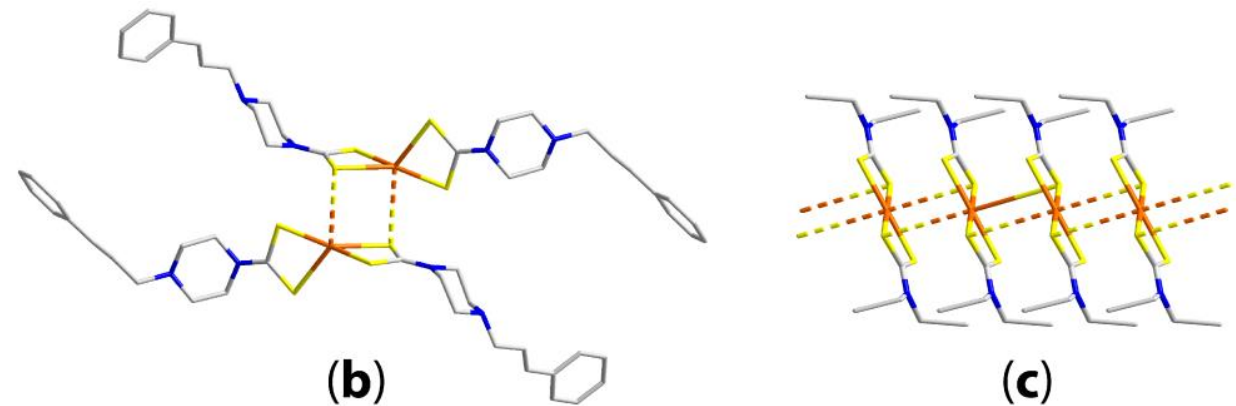

(c)

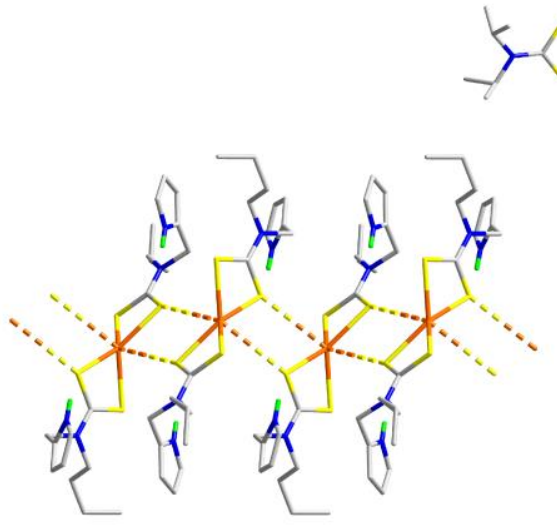

(d)

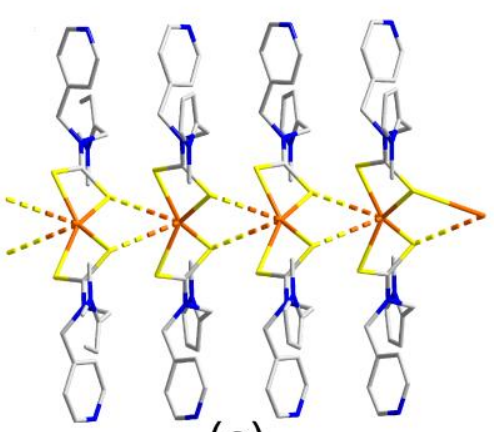

(e)

Figure 14. (a) Molecular structure of monomeric $\mathrm{Hg}\left[\mathrm{S}_{2} \mathrm{CN}(\mathrm{i}-\mathrm{Pr})_{2}\right]_{2}$ (142). Supramolecular association via $\mathrm{Hg} \cdots \mathrm{S}$ secondary bonding interactions: (b) loosely associated dimer in $\mathrm{Hg}\left[\mathrm{S}_{2} \mathrm{CN}\left(\mathrm{CH}_{2}\right)_{4}\right.$ $\left.\mathrm{NCH}_{2} \mathrm{C}(\mathrm{H})=\mathrm{C}(\mathrm{H}) \mathrm{Ph}\right](147)(\mathrm{Hg} \cdots \mathrm{S}=3.47 \AA)$; (c) linear supramolecular chain in the crystal of $\mathrm{Hg}\left(\mathrm{S}_{2} \mathrm{CNEt}_{2}\right)_{2}(\mathbf{1 5 7})(\mathrm{Hg} \cdots \mathrm{S}=3.29 \AA)$; (d) twisted chain in $\mathrm{Hg}\left[\mathrm{S}_{2} \mathrm{CN}(\mathrm{n}-\mathrm{Bu}) \mathrm{CH}_{2}(1 \mathrm{H}-\right.$ pyrrol-2-yl)] (161) $\left(\mathrm{Hg} \cdots \mathrm{S}=3.48\right.$ and $3.61 \AA$ ) ; and (e) twisted chain in $\mathrm{Hg}\left\{\mathrm{S}_{2} \mathrm{CN}\left[\mathrm{CH}_{2}(4-p y)\right] \mathrm{CH}_{2}\right.$ (1H-pyrrol-2-yl) $\}$ (162) $(\mathrm{Hg} \cdots \mathrm{S}=3.82 \AA)$. The dashed $\mathrm{Hg} \cdots \mathrm{S}$ bonds in (b-e) represent secondary bonding interactions.

Supramolecular aggregation via intermolecular $\mathrm{Hg} \cdots \mathrm{S}$ secondary bonding interactions is also found in each of $\mathrm{Hg}\left[\mathrm{S}_{2} \mathrm{CN}(\mathrm{n}-\mathrm{Bu}) \mathrm{CH}_{2}\left(1 \mathrm{H}-\right.\right.$ pyrrol-2-yl)] (161) [152] and $\mathrm{Hg}\left\{\mathrm{S}_{2} \mathrm{CN}\left[\mathrm{CH}_{2}(4-\mathrm{py})\right] \mathrm{CH}_{2}(1 \mathrm{H}-\right.$ pyrrol-2-yl)\} (162) [146]. In 161, relatively small differences in the Hg-S bond lengths, that is, 2.48 to $2.65 \AA$, are noted in the distorted tetrahedral geometry, with the widest angle being $138^{\circ}$. The sulphur atoms forming the shorter $\mathrm{Hg}-\mathrm{S}$ bonds form bridging interactions $(\mathrm{Hg} \cdots \mathrm{S}=3.48$ and $3.61 \AA$ ) to symmetry-related molecules to sustain a weakly associated chain with a twisted topology, Figure $14 \mathrm{~d}$. The molecule in $\mathbf{1 6 2}$ has the mercury atom located on a 2-fold axis of symmetry, with the dithiocarbamate chelating with similar Hg-S bond lengths of 2.50 and $2.64 \AA$ and the widest angle being $142^{\circ}$. Molecules also self-associate via very weak $\mathrm{Hg} \cdots \mathrm{S}$ interactions of $3.82 \AA$ to form a twisted one-dimensional aggregation pattern, as shown in Figure 14e. Each of the independent supramolecular synthons in $\mathbf{1 6 1}$ is symmetric, four-membered $\{\cdots \mathrm{S}-\mathrm{Hg}\}_{2}$, and with a rectangular appearance. By contrast, in 162, the synthon is non-symmetric $\{\cdots \mathrm{S}-\mathrm{Hg}-\mathrm{S} \cdots \mathrm{Hg}\}$ and has the appearance of a distorted diamond. With these differences, the structures found in $\mathbf{1 6 1}$ and 162 are assigned as motifs $Y$ and $\mathbf{Z}$, respectively.

The familiar binuclear motif seen in the zinc and cadmium dithiocarbamates is adopted by 16 mercury dithiocarbamate structures, 163-178 [109,143,149,153-163]. Being 2-fold symmetric, $\left\{\mathrm{Hg}\left[\mathrm{S}_{2} \mathrm{CN}(\mathrm{n}-\mathrm{Bu})_{2}\right]_{2}\right\}_{2}$ (165) [143] is assigned motif $\mathbf{N}$, with the rest of the molecules being motif $\mathbf{O}$. With two exceptions, the molecules adopting motif $\mathbf{O}$ are centrosymmetric; in $\left\{\mathrm{Hg}\left[\mathrm{S}_{2} \mathrm{CN}(\mathrm{Benzyl})\right.\right.$ $\mathrm{CH}_{2}$ (2-furyl) $\}_{2}$ (175) [158], two independent centrosymmetric molecules comprise the asymmetric unit, and in $\left\{\mathrm{Hg}\left[\mathrm{S}_{2} \mathrm{CN}(\mathrm{Me}) \mathrm{CH}_{2} \mathrm{Ph}\right]_{2}\right\}_{2}$ (171) [160], the molecule crystallises across a non-crystallographic 
centre. The mercury containing structures resemble the zinc analogues more than the cadmium structures, as the transannular $\mathrm{Hg} \cdots \mathrm{S}$ interaction is generally long, at least when compared to the sum of the van der Waals radii of $3.35 \AA$ [20]. Hence, the coordination geometry is best described as being based on an $S_{4}+1$ arrangement. The values calculated for $\tau$ [50] indicate geometries tending towards square-pyramidal $(\tau=0.0)$, with the minimum value of 0.01 being found for $\left\{\mathrm{Hg}\left[\mathrm{S}_{2} \mathrm{CN}(\mathrm{i}-\mathrm{Pr}) \mathrm{CH}_{2} \mathrm{CH}_{2} \mathrm{OH}\right]_{2}\right\}_{2}$ (174) [162], and with all other structures, but one, having $t<0.32$. The exceptional structure, $\left[\mathrm{Hg}\left\{\mathrm{S}_{2} \mathrm{CN}\left[\mathrm{CH}_{2} \text { (3-py) }\right] \mathrm{CH}_{2} \text { (2-ferrocenyl) }\right\}_{2}\right]_{2}$ (178) [109], has a $\tau$ value of 0.52 . $\left\{\mathrm{Hg}\left[\mathrm{S}_{2} \mathrm{CN}(\mathrm{n}-\mathrm{Bu})_{2}\right]_{2}\right\}_{2}$ (165) [143], having motif $\mathbf{L}$, had a value of $\tau=0.48$. There are non-systematic variations in the $\mathrm{Hg}-\mathrm{S}$ bond lengths although the range of the $\mathrm{Hg}-\mathrm{S}$ bond lengths is relatively narrow, as exemplified by the aforementioned $\left\{\mathrm{Hg}\left[\mathrm{S}_{2} \mathrm{CN}\left(\text { Benzyl) } \mathrm{CH}_{2} \text { (2-furyl) }\right]_{2}\right\}_{2}\right.$ (175) [158] structure, with two independent molecules, where the range of $\mathrm{Hg}$-S bond lengths of 2.46 to $2.73 \AA$ encompasses most of the Hg-S separations in the other structures, with two exceptions. Before discussing these, it is relevant to note the range of transannular interactions within the eight-membered $\left\{-\mathrm{HgSCS}_{2}\right.$ ring, that is, $3.03 \AA$ in $\left[\mathrm{Hg}\left\{\mathrm{S}_{2} \mathrm{CN}\left[\mathrm{CH}_{2} \text { (2-furyl) }\right]_{2}\right\}_{2}\right]_{2}$ (169) [158] to $3.25 \AA$ for one of the independent molecules in 175. The exceptional structures are $\left\{\mathrm{Hg}\left[\mathrm{S}_{2} \mathrm{CN}(\mathrm{Et}) \mathrm{Ph}\right]_{2}\right\}_{2}$ (173) [161] and $\left\{\mathrm{Hg}\left[\mathrm{S}_{2} \mathrm{CN}(\mathrm{i}-\mathrm{Pr}) \mathrm{CH}_{2} \mathrm{CH}_{2} \mathrm{OH}\right]_{2}\right\}_{2}$ (174) [162], whereby the transannular interactions are shorter than the bridging $\mathrm{Hg}$-S bond to the symmetry-related mercury atom. Under these circumstances, these structures represent a transition from motif $\mathbf{M}$ to motif $\mathbf{O}$, but are assigned to the latter as all $\mathrm{Hg}-\mathrm{S}$ separations are less than the sum of the respective van der Waals radii.

The capricious behaviour relating to coordination geometries, $\mathrm{Hg}$-S bond lengths, and supramolecular association via $\mathrm{Hg} \cdots \mathrm{S}$ secondary bonding interactions is no better illustrated than for the pair of structures, mononuclear and square-planar $\mathrm{Hg}\left(\mathrm{S}_{2} \mathrm{CNEt}_{2}\right)_{2}$ (157) [149], which self-associates into a supramolecular chain via $\mathrm{Hg} \cdots \mathrm{S}$ contacts, Figure $14 \mathrm{c}$, and binuclear $\left\{\mathrm{Hg}\left(\mathrm{S}_{2} \mathrm{CNEt}_{2}\right)\right]_{2}(\mathbf{1 6 3})[149,153]$, Figure 15a; that is, the same compound can adopt either motif $\mathbf{X}$ or $\mathbf{O}$, respectively. Similarly, strictly mononuclear $\mathrm{Hg}\left[\mathrm{S}_{2} \mathrm{CN}(\mathrm{i}-\mathrm{Pr})_{2}\right]_{2}$ (142) [149], motif $\mathbf{M}$, in one polymorph can also adopt binuclear motif $\mathbf{O}$ in another, as in 164 [154].

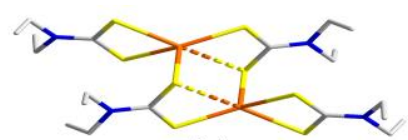

(a)

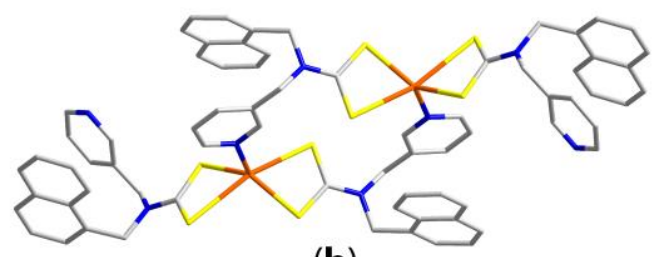

(b)

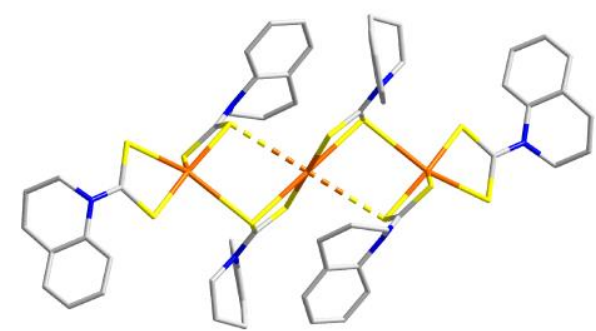

(c)

Figure 15. Molecular structures of (a) binuclear $\left[\mathrm{Hg}\left(\mathrm{S}_{2} \mathrm{CNEt}_{2}\right)_{2}\right]_{2}(\mathbf{1 6 3})$; (b) binuclear $\left[\mathrm{Hg}\left\{\mathrm{S}_{2} \mathrm{CN}\right.\right.$ $\left[\mathrm{CH}_{2}\right.$ (3-py) $] \mathrm{CH}_{2}$ (1-naphthyl) $\left.\}_{2}\right]_{2}$ (179); and (c) trinuclear $\left[\mathrm{Hg}\left(\mathrm{S}_{2} \mathrm{CNR}^{2}\right)_{2}\right]_{3}(\mathbf{1 8 0})$, where $\mathrm{NR}^{2}$ is $1,2,3,4$ tetrahydroquinoline. The dashed $\mathrm{Hg} \cdots \mathrm{S}$ bonds represent weak interactions. 
The two remaining zero-dimensional aggregates among the binary mercury dithiocarbamates have precedents in their lower congenors. The centrosymmetric binuclear compound, $\left[\mathrm{Hg}\left\{\mathrm{S}_{2} \mathrm{CN}\right.\right.$ $\left[\mathrm{CH}_{2}\right.$ (3-py) $] \mathrm{CH}_{2}$ (1-naphthyl) $\left.\}_{2}\right]_{2}$ (179) [39], Figure 15b, has one chelating dithiocarbamate ligand and one bridging ligand, whereby one end chelates a mercury atom and bridges another via the pyridyl-nitrogen atom; this structure conforms to motif $\mathbf{Q}$. The $\mathrm{NS}_{4}$ coordination geometry is almost intermediate between the ideal square-pyramidal $(\tau=0.0)$ and trigonal-bipyramidal $(\tau=1.0)$ as the value of $\tau$ is calculated to be 0.48. The molecule of $\left[\mathrm{Hg}\left(\mathrm{S}_{2} \mathrm{CNR}^{2}\right)_{2}\right]_{3}$ (180) [145] is trinuclear, Figure $15 \mathrm{c}$, and allowing for differences in M-S separations, closely resembles motif $\mathbf{S} ; \mathrm{NR}^{2}$ is 1,2,3,4-tetrahydroquinoline. The central mercury atom in $\mathbf{1 8 0}$ is located on a centre of inversion, is coordinated asymmetrically ( 2.37 and $2.95 \AA$ ) by two dithiocarbamate ligands, and is connected to the two outer $\mathrm{Hg}\left(\mathrm{S}_{2} \mathrm{CNR}^{2}\right)_{2}$ residues by $\mathrm{Hg} \ldots \mathrm{S}$ contacts of 3.05 and $3.37 \AA$, that is, within and just outside the sum of the van der Waals radii value of $3.35 \AA$ [20]. Thus, the coordination geometry for the central mercury atom resembles that seen in motif $X$, which is best described as $S_{4}+S_{2}$ with the weakly bound sulphur atoms in trans positions. The outer mercury atoms adopt heavily distorted five-coordinate geometries, as seen in the value of $\tau=0.33$, resembling the geometries found for the majority of structures adopting motif $\mathbf{O}$.

There are five binary mercury dithiocarbamate structures that adopt one- or two-dimensional aggregation patterns in their crystals. The first of these, $\left\{\mathrm{Hg}\left[\mathrm{S}_{2} \mathrm{CN}(\mathrm{Me}) \mathrm{CH}_{2}(4-\mathrm{py})\right]_{2}\right\}_{\mathrm{n}}$ (181) [72], features an S,S-chelating dithiocarbamate ligand and another which chelates the same mercury atom while at the same time bridging a symmetry-related ligand to form a linear one-dimensional polymer, Figure 16a. The resulting $\mathrm{NS}_{4}$ donor set is based on a square-pyramidal geometry, with the calculated value of $\tau$ being 0.07 compared to the ideal value for a square-pyramid of $\tau=0.0$ [50]. In this description, the nitrogen atom occupies an apical position. This linear aggregation does not have a precedent herein, so is assigned motif $\mathbf{Z}$. In $\left[\mathrm{Hg}\left\{\mathrm{S}_{2} \mathrm{CN}\left[\mathrm{CH}_{2}(4-\mathrm{py})\right] \mathrm{CH}_{2} \text { (1,3-benzodioxo-5-yl) }\right\}_{2}\right]_{n}(\mathbf{1 8 2})$ [72], which has only one pyridyl-nitrogen donor atom per repeat unit, compared with two in 181, a different aggregation pattern is found, Figure 16b. The modes of coordination of the dithiocarbamate ligands in $\mathbf{1 8 2}$ are as for $\mathbf{1 8 1}$ but, in the former, these generate zig-zag chains being propagated by glide-symmetry. The $\mathrm{NS}_{4}$ donor set is also as for $\mathbf{1 8 1}$ but, the distortion is greater from the ideal geometry, with $\tau$ being 0.20 . This coordination polymer, with precedents, is assigned as motif $\mathbf{P}$.

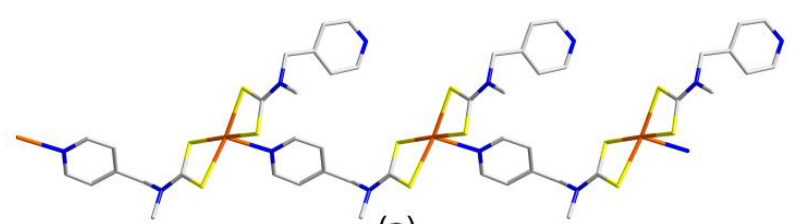

(a)

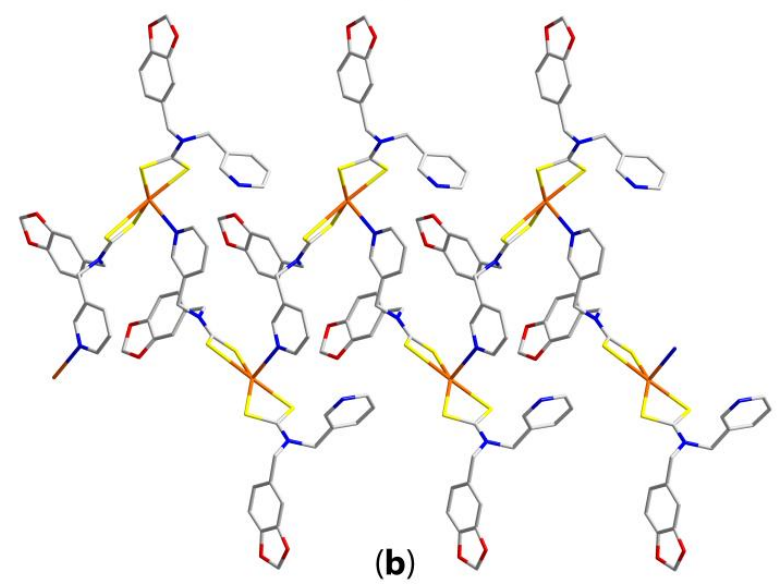

Figure 16. One-dimensional aggregation in (a) $\left\{\mathrm{Hg}\left[\mathrm{S}_{2} \mathrm{CN}(\mathrm{Me}) \mathrm{CH}_{2}(4-\mathrm{py})\right]_{2}\right\}_{\mathrm{n}}(\mathbf{1 8 1})$ and (b) $\left[\mathrm{Hg}\left\{\mathrm{S}_{2} \mathrm{CN}\right.\right.$ $\left[\mathrm{CH}_{2}\right.$ (4-py) $] \mathrm{CH}_{2}$ (1,3-benzodioxo-5-yl) $\left.\}_{2}\right]_{\mathrm{n}}$ (182). 
In $\left\{\mathrm{Hg}\left[\mathrm{S}_{2} \mathrm{CN}\left[\mathrm{CH}_{2} \text { (4-py) }\right] \mathrm{CH}_{2} \text { (2-furyl) }\right]_{2}\right\}_{\mathrm{n}}$ (183) [72], both pyridyl-nitrogen atoms are involved in the coordination to mercury, Figure 17, in contrast to the situation in each of $\mathbf{1 8 1}$ and $\mathbf{1 8 2}$. The extra participation of the pyridyl-nitrogen atoms results in a trans- $\mathrm{N}_{2} \mathrm{~S}_{4}$ donor set, a distorted octahedral geometry, and a two-dimensional array with a flat topology, that is, an aggregation pattern conforming to motif $\mathbf{R}$.

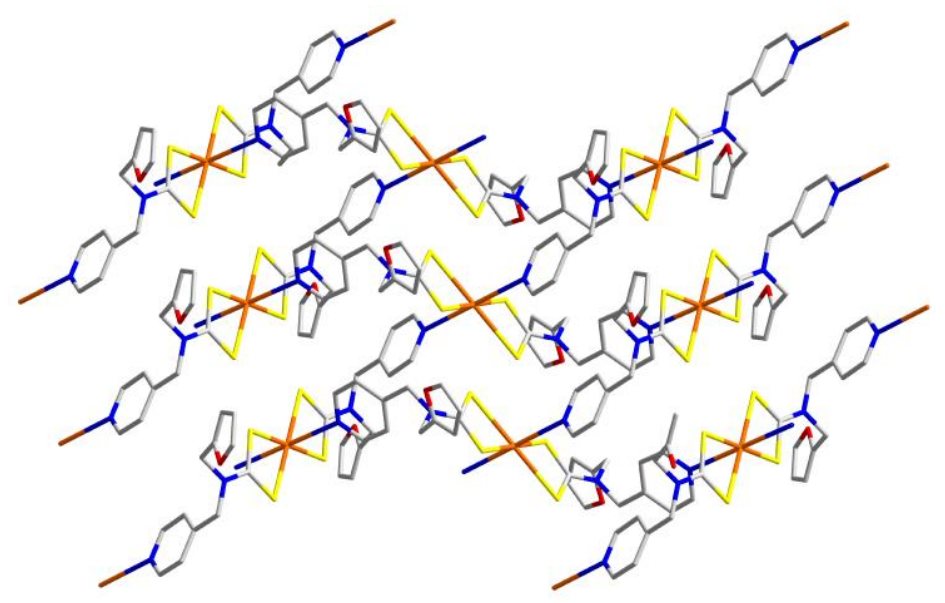

Figure 17. Two-dimensional aggregation in $\left\{\mathrm{Hg}\left[\mathrm{S}_{2} \mathrm{CN}\left[\mathrm{CH}_{2} \text { (4-py) }\right] \mathrm{CH}_{2} \text { (2-furyl) }\right]_{2}\right\}_{\mathrm{n}}$ (183).

A distinct motif, motif AA, is found in the crystal of $\left[\mathrm{Hg}\left\{\mathrm{S}_{2} \mathrm{CN}\left[\left(\mathrm{CH}_{2}\right)_{2} \mathrm{Ph}\right] \mathrm{CH}_{2}(3-\mathrm{py})\right\}_{2}\right]_{n}$ (184) [72]. There are two independent $\mathrm{Hg}\left\{\mathrm{S}_{2} \mathrm{CN}\left[\left(\mathrm{CH}_{2}\right)_{2} \mathrm{Ph} \mathrm{CH}_{2}(3-\mathrm{py})\right\}_{2}\right.$ units in the asymmetric unit and these are connected into a supramolecular polymer. As viewed from Figure 18a, the coordination geometry for each is very similar, with the independent bridging Hg-S distances being 2.90 and $2.92 \AA$. The relationship to motif $\mathbf{O}$ is apparent in that each repeat unit participates in one accepting and one donating Hg-S interaction, but in motif AA, these occur on either side of the molecule to generate a chain rather than a dimer, as in $\mathbf{O}$. The values of $\tau$ for each of the independent mercury atoms are equal at 0.57 , consistent with highly distorted $\mathrm{S}_{5}$ coordination geometries. The last structure to be described, that is, $\left[\mathrm{Hg}\left\{\mathrm{S}_{2} \mathrm{CN}\left[\left(\mathrm{CH}_{2}\right)_{2} \mathrm{Ph}\right] \mathrm{CH}_{2}(1 \mathrm{H}-\text { pyrrol-2-yl) }\}_{2}\right]_{n}\right.$ (185) [152], conforms to motif $\mathbf{V}$, being a linear coordination polymer, Figure $18 \mathbf{b}$, as each dithiocarbamate ligand is tri-connective, chelating one mercury atom while simultaneously bridging another; the mercury atom lies on a 2-fold axis.

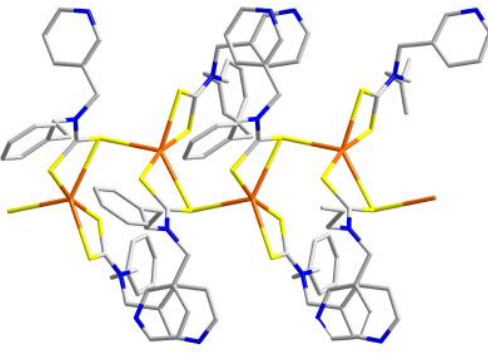

(a)

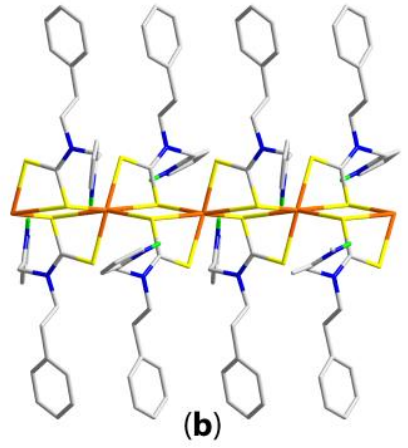

(b)

Figure 18. One-dimensional aggregation in (a) $\left[\mathrm{Hg}\left\{\mathrm{S}_{2} \mathrm{CN}\left[\left(\mathrm{CH}_{2}\right)_{2} \mathrm{Ph}\right] \mathrm{CH}_{2}(3-\mathrm{py})\right\}_{2}\right]_{\mathrm{n}}$ (184) and (b) $\left[\mathrm{Hg}\left\{\mathrm{S}_{2} \mathrm{CN}\left[\left(\mathrm{CH}_{2}\right)_{2} \mathrm{Ph}\right] \mathrm{CH}_{2}(1 \mathrm{H}-\text { pyrrol-2-yl) }\}_{2}\right]_{\mathrm{n}}\right.$ (185).

\section{Overview and Conclusions}

The foregoing bibliographic overview highlights the diverse structural chemistry exhibited by the binary zinc-triad 1,1-dithiolates, with 27 distinct structural motifs documented. The observed diversity 
in their crystals is correlated, in part, with the different bonding requirements of the zinc, cadmium, and mercury centres. The nature of the 1,1-dithiolate ligand also plays a determining role, with bridging propensities being the greatest for xanthate and dithiophosphate ligands. Dithiocarbamates, by virtue of the significant contribution (40\%) of the ${ }^{2-} \mathrm{S}_{2} \mathrm{C}=\mathrm{N}^{+} \mathrm{RR}^{\prime}$ anion to the overall electronic structure, are very effective chelators for metal centres and tend to be less likely to be engaged in extensive bridging interactions. In the context of the design of extended networks, this shortcoming can be overcome by incorporating other potential donor atoms in the organic substituents in the ligands, most notably pyridyl-nitrogen donors, to promote supramolecular aggregation. Steric effects exerted by the organic substituents can influence the supramolecular aggregation, in particular by militating weaker M-S bonds/M $\cdots \mathrm{S}$ secondary bonding interactions. The above notwithstanding, very significant differences are evident among the 27 identified structural motifs, that is, between closely related compounds or even between polymorphs, and the challenge remains to rationalise the appearance of these and ultimately to use this information to predict structures based on chemical composition.

Acknowledgments: Sunway University is gratefully acknowledged for continuing support for chemical crystallography studies. This research received no external funding.

Conflicts of Interest: The author declares no conflict of interest.

\section{References and Notes}

1. Haiduc, I. 1,1-Dithiolato ligands and related selenium and tellurium compounds. In Handbook of Chalcogen Chemistry; Devillanova, F.A., Ed.; Royal Society of Chemistry: Cambridge, UK, 2007; pp. 593-643, ISBN 978-0-85404-366-8.

2. Zeise, W.C. Recueil de Memoires del' Acad. Roy. Des Sciences de Copenhagen 1815, 1, 1.

3. Pishchimuka, P.S. Action of phosphorus pentasulfide on alcohol. J. Russ. Phys. Chem. Soc. 1925, 56, 11-14.

4. Johnson, D.W.; Hils, J.E. Phosphate esters, thiophosphate esters and metal thiophosphates as lubricant additives. Lubricants 2013, 1, 132-148. [CrossRef]

5. Hogarth, G. Transition metal dithiocarbamates: 1978-2003. Prog. Inorg. Chem. 2005, 53, 71-561. [CrossRef]

6. Dobus, H. Ueber die Verbindungen der Sulfocarbaminsäure. Justus Liebigs Annalen der Chemie 1850, 73, $26-34$. [CrossRef]

7. Delépine, M. Metallic salts of dithiocarbamic acids; preparation of isothiocyanates in the aliphatic series. Compt. Rend. 1907, 144, 1125-1127.

8. Coucouvanis, D. The chemistry of the dithioacid and 1,1-dithiolate complexes. Prog. Inorg. Chem. 1970, 11, 234-371. [CrossRef]

9. Eisenberg, R. Structural systematics of 1,1- and 1,2-dithiolato chelates. Prog. Inorg. Chem. 1970, 12, $295-369$. [CrossRef]

10. Coucouvanis, D. The chemistry of the dithioacid and 1,1-dithiolate complexes, 1968-1977. Prog. Inorg. Chem. 1979, 26, 301-469. [CrossRef]

11. Winter, G. Inorganic xanthates. Rev. Inorg. Chem. 1980, 2, 253-342.

12. Tiekink, E.R.T.; Winter, G. Inorganic xanthates: A structural perspective. Rev. Inorg. Chem. 1992, 12, $183-302$. [CrossRef]

13. Tiekink, E.R.T.; Haiduc, I. Stereochemical aspects of metal xanthate complexes: Molecular structures and supramolecular self-assembly. Prog. Inorg. Chem. 2005, 54, 127-319. [CrossRef]

14. Haiduc, I.; Sowerby, D.B. Stereochemical aspects of phosphor-1,1-dithiolato metal complexes: Coordination patterns, molecular structures and supramolecular associations in dithiophosphinates and related compounds. Polyhedron 1996, 15, 2469-2521. [CrossRef]

15. Heard, P.J. Main group dithiocarbamate complexes. Prog. Inorg. Chem. 2005, 53, 1-69. [CrossRef]

16. Cox, M.J.; Tiekink, E.R.T. The diverse coordination patterns in the structures of zinc, cadmium and mercury bis(1,1-dithiolates). Rev. Inorg. Chem. 1997, 17, 1-23. [CrossRef]

17. Tiekink, E.R.T. Molecular architecture and supramolecular association in the zinc-triad 1,1-dithiolates. Steric control as a design element in crystal engineering? CrystEngComm 2003, 5, 101-113. [CrossRef]

18. Tiekink, E.R.T. Perplexing coordination behaviour of potentially bridging bipyridyl-type ligands in the coordination chemistry of zinc and cadmium 1,1-dithiolate compounds. Crystals 2018, 8, 18. [CrossRef] 
19. Groom, C.R.; Bruno, I.J.; Lightfoot, M.P.; Ward, S.C. The Cambridge Structural Database. Acta Crystallogr. B Struct. Sci. Cryst. Eng. Mater. 2016, 72, 171-179. [CrossRef] [PubMed]

20. Spek, A.L. Structure validation in chemical crystallography. Acta Crystallogr. D Biol. Cryst. 2009, 65, 148-155. [CrossRef] [PubMed]

21. DIAMOND, version 3.2k; K. Brandenburg \& M. Berndt GbR: Bonn, Germany, 2006.

22. Ikeda, T.; Hagihara, H. The crystal structure of zinc ethylxanthate. Acta Crystallogr. 1966, 21, 919-927. [CrossRef]

23. Lai, C.S.; Lim, Y.X.; Yap, T.C.; Tiekink, E.R.T. Molecular paving with zinc thiolates. CrystEngComm 2002, 4, 596-600. [CrossRef]

24. Ito, T. The crystal structure of zinc isopropylxanthate. Acta Crystallogr. Sect. B Struct. Crystallogr. Cryst. Chem. 1972, 28, 1697-1704. [CrossRef]

25. Cox, M.J.; Tiekink, E.R.T. Structural features of zinc(II) bis(O-alkyldithiocarbonate) and zinc(II) bis(N,N-dialkyldithiocarbamate) compounds. Z. Kristallogr. 1999, 214, 184-190. [CrossRef]

26. Young, V.G., Jr.; Tiekink, E.R.T. Bis(O-methyldithiocarbonato)cadmium(II). Acta Crystallogr. Sect. E Struct. Rep. Online 2002, 58, m537-m539. [CrossRef]

27. Iimura, Y.; Ito, T.; Hagihara, H. The crystal structure of cadmium ethylxanthate. Acta Crystallogr. Sect. B Struct. Crystallogr. Cryst. Chem. 1972, 28, 2271-2279. [CrossRef]

28. Macreadie, L.K.; Maynard-Casely, H.E.; Batten, S.R.; Turner, D.R.; Chesman, A.S.R. Soluble xanthate compounds for the solution deposition of metal sulfide thin films. ChemPlusChem 2015, 80, 107-118. [CrossRef]

29. Tomlin, D.W.; Cooper, T.M.; Zelmon, D.E.; Gebeyehu, Z.; Hughes, J.M. Cadmium isopropylxanthate. Acta Crystallogr. Sect. C Cryst. Struct. Commun. 1999, 55, 717-719. [CrossRef]

30. Tiekink, E.R.T. On the structure of cadmium isopropylxanthate. Corrigendum. Acta Crystallogr. Sect. C Cryst. Struct. Commun. 1999, 55, 1176. [CrossRef]

31. Rietveld, H.M.; Maslen, E.N. The crystal structure of cadmium n-butyl xanthate. Acta Crystallogr. 1965, 18, 429-436. [CrossRef]

32. Abrahams, B.F.; Hoskins, B.F.; Tiekink, E.R.T.; Winter, G. Investigation of a new xanthate ligand. The crystal and molecular structures of nickel and cadmium (methoxyethyl)xanthates. Aust. J. Chem. 1988, 41, 1117-1122. [CrossRef]

33. Tiekink, E.R.T. Bis(O-methyldithiocarbonato)mercury(II). Acta Crystallogr. Sect. C Cryst. Struct. Commun. 1987, 43, 448-450. [CrossRef]

34. Watanabe, Y. Mercury ethylxanthate. Acta Crystallogr. Sect. B Struct. Crystallogr. Cryst. Chem. 1977, 33, 3566-3568. [CrossRef]

35. Chieh, C.; Moynihan, K.J. Xanthate and dithiocarbamate complexes of group IIlb elements, and an interesting relationship between two mercury(II) ethylxanthate phases. Acta Crystallogr. Sect. B Struct. Crystallogr. Cryst. Chem. 1980, 36, 1367-1371. [CrossRef]

36. Hounslow, A.M.; Tiekink, E.R.T. Correlations between nuclear magnetic resonance spectra and crystal structure. III. A ${ }^{13} \mathrm{C}$ nuclear magnetic resonance study in the solid state of bis(xanthato) complexes of mercury(II); The crystal and molecular structure of bis(n-propyl-dithiocarbonato)mercury(II). J. Crystallogr. Spectrosc. Res. 1991, 21, 133-137. [CrossRef]

37. Watanabe, Y. The structure of mercury(II) isopropylxanthate. Acta Crystallogr. Sect. B Struct. Crystallogr. Cryst. Chem. 1981, 37, 553-556. [CrossRef]

38. Cox, M.J.; Tiekink, E.R.T. Structural diversity in mercury(II) bis(O-alkyldithiocarbonate) compounds. Z. Kristallogr. 1999, 214, 486-491. [CrossRef]

39. Rajput, G.; Yadav, M.K.; Thakur, T.S.; Drew, M.G.B.; Singh, N. Versatile coordination environment and interplay of metal assisted secondary interactions in the organization of supramolecular motifs in new $\mathrm{Hg}(\mathrm{II}) / \mathrm{PhHg}$ (II) dithiolates. Polyhedron 2014, 69, 225-233. [CrossRef]

40. Tiekink, E.R.T. Aggregation patterns in the crystal structures of organometallic Group XV 1,1-dithiolat.es: The influence of the Lewis acidity of the central atom, metal- and ligand-bound steric bulk, and coordination potential of the 1,1-dithiolate ligands upon supramolecular architecture. CrystEngComm 2006, 8, 104-118. [CrossRef] 
41. Chen, D.; Lai, C.S.; Tiekink, E.R.T. Supramolecular aggregation in diimine adducts of zinc(II) dithiophosphates: Controlling the formation of monomeric, dimeric, polymeric (zig-zag and helical), and 2-D motifs. CrystEngComm 2006, 8, 51-58. [CrossRef]

42. Kang, J.-G.; Shin, J.-S.; Cho, D.-H.; Jeong, Y.-K.; Park, C.; Soh, S.F.; Lai, C.S.; Tiekink, E.R.T. Steric control over supramolecular polymer formation in trans-1,2-bis(4-pyridyl)ethylene adducts of zinc xanthates: Implications for luminescence. Cryst. Growth Des. 2010, 10, 1247-1256. [CrossRef]

43. Tiekink, E.R.T. Structural chemistry of organotin carboxylates: A review of the crystallographic literature. Appl. Organomet. Chem. 1991, 5, 1-23. [CrossRef]

44. Willem, R.; Verbruggen, I.; Gielen, M.; Biesemans, M.; Mahieu, B.; Basu Baul, T.S.; Tiekink, E.R.T. Correlating Mössbauer and solution- and solid-state ${ }^{117} \mathrm{Sn}$ NMR data with X-ray diffraction structural data of triorganotin 2-[(E)-2-(2-hydroxy-5-methylphenyl)-1-diazenyl]benzoates. Organometallics 1998, 17, 5758-5766. [CrossRef]

45. Dakternieks, D.; Duthie, A.; Smyth, D.R.; Stapleton, C.P.D.; Tiekink, E.R.T. Steric control over molecular structure and supramolecular association exerted by tin- and ligand-bound groups in diorganotin carboxylates. Organometallics 2003, 22, 4599-4603. [CrossRef]

46. Alcock, N.W. Secondary bonding to nonmetallic elements. Adv. Inorg. Chem. Radiochem. 1972, 15, 1-58. [CrossRef]

47. Pyykkö, P. Strong closed-shell interactions in inorganic chemistry. Chem. Rev. 1997, 97, 597-636. [CrossRef] [PubMed]

48. Haiduc, I. Supramolecular associations, secondary bonds, quasi-cyclic structures and heterogeometrism in metal derivatives of phosphorus- and arsenic-based thioacids and oxo analogs. Coord. Chem. Rev. 1997, 158, 325-358. [CrossRef]

49. Buntine, M.A.; Cox, M.J.; Lim, Y.X.; Yap, T.C.; Tiekink, E.R.T. Crystal structure of anhydrous potassium O-n-propyldithiocarbonate. Theoretical calculations of O-alkyl dithiocarbonates. Z. Kristallogr. 2003, 218, 56-61. [CrossRef]

50. Addison, A.W.; Rao, T.N.; Reedijk, J.; van Rijn, J.; Verschoor, G.C. Synthesis, structure, and spectroscopic properties of copper(II) compounds containing nitrogen-sulphur donor ligands; the crystal and molecular structure of aqua[1,7-bis(N-methylbenzimidazol-2'-yl)-2,6-dithiaheptane]copper(II) perchlorate. J. Chem. Soc. Dalton Trans. 1984, 1349-1356. [CrossRef]

51. Ito, T.; Igarashi, T.; Hagihara, H. The crystal structure of metal diethyldithiophosphates. I. Zinc diethyldithiophosphate. Acta Crystallogr. Sect. B Struct. Crystallogr. Cryst. Chem. 1969, 25, 2303-2309. [CrossRef]

52. Lawton, S.L.; Kokotailo, G.T. Crystal and molecular structures of zinc and cadmium O,O-diisopropyl phosphorodithioates. Inorg. Chem. 1969, 8, 2410-2421. [CrossRef]

53. Menzer, S.; Phillips, J.R.; Slawin, A.M.Z.; Williams, D.J.; Woollins, J.D. Structural characterisation of basic zinc $O, O^{\prime}$-dialkyl dithiophosphosphate and two isomeric examples of zinc monothiophosphates. J. Chem. Soc. Dalton Trans. 2000, 3269-3273. [CrossRef]

54. Ivanov, A.V.; Antzutkin, O.N.; Larsson, A.-C.; Kritikos, M.; Forsling, W. Polycrystalline and surface $\mathrm{O}, \mathrm{O}^{\prime}$-dialkyldithiophosphate zinc(II) complexes: Preparation, ${ }^{31} \mathrm{P} \mathrm{CP} / \mathrm{MAS}$ NMR and single-crystal X-ray diffraction studies. Inorg. Chim. Acta 2001, 315, 26-35. [CrossRef]

55. Ito, T.; Otake, M. Linear-chain structure of bis $\left(O, O^{\prime}\right.$-dimethyldithiophosphato)cadmium(II). Acta Crystallogr. Sect. C Cryst. Struct. Commun. 1996, 52, 3024-3025. [CrossRef]

56. Ivanov, A.V.; Gerasimenko, A.V.; Antzutkin, O.N.; Forsling, W. The unique alternation of conformationally different ('chair'-'saddle') eight-membered metallocycles $\left[\mathrm{Cd}_{2} \mathrm{~S}_{4} \mathrm{P}_{2}\right]$ in the chains of cadmium dialkyldithiophosphates: ${ }^{13} \mathrm{C},{ }^{31} \mathrm{P},{ }^{113} \mathrm{Cd} \mathrm{CP} / \mathrm{MAS} \mathrm{NMR}$ and single-crystal X-ray diffraction studies. Inorg. Chim Acta 2005, 358, 2585-2594. [CrossRef]

57. Ivanov, A.V.; Antzutkin, O.N.; Forsling, W.; Bostrom, D.; Yegao, Y.; Rodionova, N.A. Structural organization and spectral properties of cadmium and nickel(II) $\mathrm{O}, \mathrm{O}^{\prime}$-di-iso-butyl phosphorodithioate complexes as probed by single-crystal X-ray diffraction and CP/MAS NMR (C-13, P-31, Cd-113). Dok. Phys. Chem. 2002, 387, 299-303. [CrossRef]

58. Ivanov, A.V.; Loseva, O.V.; Ivanov, M.A.; Konfederatov, V.A.; Gerasimenko, A.V.; Antzutkin, O.N.; Forsling, W. Crystalline cadmium dialkyl phosphorodithioate complexes: Synthesis and structural organization as probed by multinuclear C-13, P-31, and Cd-113 CP/MAS NMR and single-crystal X-ray diffraction. Russ. J. Inorg. Chem. 2007, 52, 1595-1602. [CrossRef] 
59. Casas, J.S.; Castiñeiras, A.; Garcia-Tasende, M.S.; Sánchez, A.; Sordo, J.; Vázquez-López, E.M. The X-ray crystal structure of bis(dicyclohexyldithiophosphato)cadmium(II). Polyhedron 1995, 14, 2055-2058. [CrossRef]

60. Ito, T. Poly[bis $\left(\mu_{2}-\mathrm{O}, \mathrm{O}^{\prime}\right.$-dimethyldithiophosphato)mercury(II)]. Acta Crystallogr. E Cryst. Comm. 2006, 62, m1666-m1667. [CrossRef]

61. Lawton, S.L. Crystal and molecular structure of the polymeric complex mercuric $O, O^{\prime}$-diisopropylphosphorodithioate, $\left.\mathrm{Hg}\left[\mathrm{i}-\mathrm{C}_{3} \mathrm{H}_{7} \mathrm{O}\right)_{2} \mathrm{PS}_{2}\right]_{2}$. Inorg. Chem. 1971, 10, 328-335. [CrossRef]

62. Casas, J.S.; Castellano, E.E.; Ellena, J.; Haiduc, I.; Sánchez, A.; Sordo, J. The crystal and molecular structure of mercury(II) bis(isopropyl)dithiophosphate, $\mathrm{Hg}\left[\mathrm{S}_{2} \mathrm{P}\left(\mathrm{OPr}^{\mathrm{i}}\right)_{2}\right]_{2}$, revisited: New comments about its supramolecular self-organization. J. Chem. Crystallogr. 1999, 29, 831-836. [CrossRef]

63. Murat Taş, M.; Yağan, M.; Bati, H.; Bati, B.; Büyükgüngör, O. Supramolecular self-organization in mercury(II) dicyclopentyldithiophosphate polynuclear complex. Phosphorus. Sulfur. Silicon Rel. Elements 2009, 185, 242-248. [CrossRef]

64. Hogarth, G.; Rainford-Brent, E.-J.C.-R.C.R.; Richards, I. Functionalised dithiocarbamate complexes: Synthesis and molecular structures of bis(2-methoxyethyl)dithiocarbamate complexes $\left[\mathrm{M}\left\{\mathrm{S}_{2} \mathrm{CN}\left(\mathrm{CH}_{2} \mathrm{CH}_{2} \mathrm{OMe}\right)_{2}\right\}_{2}\right]$ $(\mathrm{M}=\mathrm{Ni}, \mathrm{Cu}, \mathrm{Zn})$ and $\left[\mathrm{Cu}\left\{\mathrm{S}_{2} \mathrm{CN}\left(\mathrm{CH}_{2} \mathrm{CH}_{2} \mathrm{OMe}\right)_{2}\right\}_{2}\right]\left[\mathrm{ClO}_{4}\right]$. Inorg. Chim. Acta 2009, 362, 1361-1364. [CrossRef]

65. Decken, A.; Gossage, R.A.; Chan, M.Y.; Lai, C.S.; Tiekink, E.R.T. Crystallographic report: $\operatorname{Bis}(N, N$-dibenzyldithiocarbamato)zinc(II). Appl. Organomet. Chem. 2004, 18, 101-102. [CrossRef]

66. Chan, M.Y.; Lai, C.S.; Tiekink, E.R.T. Crystallographic report: Bis(N-cyclohexyl,N-methyldithio-carbamato) zinc(II). Appl. Organomet. Chem. 2004, 18, 298. [CrossRef]

67. Awang, N.; Baba, I.; Yamin, B.M.; Ng, S.W. Bis( $N$-isobutyl-N-propyldithiocarbamato-k $\left.{ }^{2} S, S^{\prime}\right)$ zinc(II). Acta Crystallogr. Sect. E Struct. Rep. Online 2010, 66, m215. [CrossRef] [PubMed]

68. Srinivasan, N.; Thirumaran, S. Synthesis of ZnS nanoparticles from pyridine adducts of zinc(II) dithiocarbamates. Compt. Rend. Chim. 2014, 17, 964-970. [CrossRef]

69. Reck, G.; Becker, R. Bis[N-n-butyl-N-(3,5-di-tert-butyl-2-hydroxybenzyl)dithiocarbamato-k $\left.{ }^{2} S, S^{\prime}\right]$ zinc(II). Bis(N-isobutyl-N-propyldithiocarbamato-k $\left.{ }^{2} S, S^{\prime}\right)$ zinc(II). Acta Crystallogr. Sect. E Struct. Rep. Online 2010, 66, m234-m235. [CrossRef]

70. Yadav, R.; Trivedi, M.; Kociok-Kohn, G.; Chauhan, R.; Kumar, A.; Gosavi, S.W. Ferrocenyl dithiocarbamate based $\mathrm{d}^{10}$ transition-metal complexes as potential co-sensitizers in dye-sensitized solar cells. Eur. J. Inorg. Chem. 2016, 1013-1021. [CrossRef]

71. Reck, G. Pers. Commun. Camb. Str. Database, Refcode: NEQJEZ, 2006.

72. Singh, V.; Kumar, V.; Gupta, A.N.; Drew, M.G.B.; Singh, N. Effect of pyridyl substituents leading to the formation of green luminescent mercury(II) coordination polymers, zinc(II) dimers and a monomer. New J. Chem. 2014, 38, 3737-3748. [CrossRef]

73. Gomathi, G.; Sathiyaraj, E.; Thirumaran, S.; Ciattini, S. Effect of functionlization of N,N-dibenzyldithiocarbamate: Synthesis, spectral and structural studies on bis(N-benzyl- $N$-(4-methoxybenzyl)dithiocarbamato-S,S')zinc(II) and bis(N-benzyl-N-(4-cholrobenzyl)dithiocarbamato-S, $\left.\mathrm{S}^{\prime}\right)$ cadmium(II) and their use for the preparation of MS $(\mathrm{M}=\mathrm{Zn}, \mathrm{Cd})$. J. Sulfur Chem. 2016, 37, 23-36. [CrossRef]

74. Manar, K.; Yadav, C.; Tiwari, N.; Singh, R.; Yadav, A.; Drew, M.G.B.; Singh, N. Effect of functionalities on the crystal structures of new zinc(II) dithiocarbamates: A combined anti-leishmanial and thermal decomposition study. CrystEngComm 2017, 19, 2660-2672. [CrossRef]

75. Sathiyaraj, E.; Tamilvanan, S.; Thirumaran, S.; Ciattini, S. Effect of functionalization of N-bound organic moiety in zinc(II) dithiocarbamate complexes on structure, biological properties and morphology of zinc sulfide nanoparticles. Polyhedron 2017, 128, 133-144. [CrossRef]

76. Klug, H.P. The crystal structure of zinc dimethyldithiocarbamate. Acta Crystallogr. 1966, 21, 536-546. [CrossRef]

77. Ivanov, A.V.; Ivakhnenko, A.V.; Gerasimenko, E.V.; Forshling, W. A comparative study of the structural organization of zinc complexes with dialkyl-substituted and cyclic dithiocarbamate ligands: Synthesis, single-crystal X-ray diffraction, and CP/MAS C-13 and N-15 NMR. Russ. J. Inorg. Chem. 2003, 48, 45-54.

78. Paz, F.A.A.; Neves, M.C.; Trindade, T.; Klinowski, J. The first dinuclear zinc(II) dithiocarbamate complex with butyl substituent groups. Acta Crystallogr. Sect. E Struct. Rep. Online 2003, 59, m1067-m1069. [CrossRef]

79. Tiekink, E.R.T. Redetermination of the crystal structure of dimeric bis( $N, N^{\prime}$-diethyldithiocarbamato)zinc, $\left[\mathrm{Zn}\left(\mathrm{S}_{2} \mathrm{CNEt}_{2}\right)_{2}\right]_{2}$. Z. Kristallogr. New Cryst. Struct. 2000, 215, 445-446. [CrossRef] 
80. Sreehari, N.; Varghese, B.; Manoharan, P.T. Crystal and molecular structure of dimeric bis[N,N-di-npropyldithiocarbamato]zinc(II) and the study of exchange-coupled copper(II)-copper(II) pairs in its lattice. Inorg. Chem. 1990, 29, 4011-4015. [CrossRef]

81. Miyamae, H.; Ito, M.; Iwasaki, H. The structure of zinc(II) $N, N$-diisopropyldithiocarbamate $\{$ bis $[\mathrm{m}-(\mathrm{N}, N-$ diisopropyldithiocarbamato)-m-S,S']-bis(N,N-diisopropyldithiocarbamato)dizinc(II)\}. Acta Crystallogr. Sect. B Struct. Crystallogr. Cryst. Chem. 1979, 35, 1480-1482. [CrossRef]

82. Kellö, E.; Vrabel, V.; Kettmann, V.; Garaj, J. The crystal and molecular-structure of the complex of zinc(ii) with di-mu-diallyldithiocarbamate-bis(diallyldithiocarbamate). Collect. Czech. Chem. Commun. 1983, 48, 1272-1280. [CrossRef]

83. Benson, R.E.; Ellis, C.A.; Lewis, C.E.; Tiekink, E.R.T. 3D-, 2D- and 1D-supramolecular structures of $\left\{\mathrm{Zn}\left[\mathrm{S}_{2} \mathrm{CN}\left(\mathrm{CH}_{2} \mathrm{CH}_{2} \mathrm{OH}\right) \mathrm{R}\right]_{2}\right\}_{2}$ and their $\left\{\mathrm{Zn}\left[\mathrm{S}_{2} \mathrm{CN}\left(\mathrm{CH}_{2} \mathrm{CH}_{2} \mathrm{OH}\right) \mathrm{R}\right]_{2}\right\}_{2}\left(4,4^{\prime}\right.$-bipyridine) adducts for $\mathrm{R}=\mathrm{CH}_{2} \mathrm{CH}_{2} \mathrm{OH}$, Me or Et: Polymorphism and pseudo-polymorphism. CrystEngComm 2007, 9, 930-940. [CrossRef]

84. Thirumaran, S.; Venkatachalam, V.; Manohar, A.; Ramalingam, G.; Bocelli, G.; Cantoni, A. Synthesis and characterization of bis(N-methyl-N-ethanol-dithiocarbamato)M(II) (M = Zn, Cd, Hg) and bis(N,N (iminodiethylene)-bisphthalimidedithiocarbamato) $\mathrm{M}(\mathrm{II})(\mathrm{M}=\mathrm{Zn}, \mathrm{Cd}, \mathrm{Hg})$ complexes. Single crystal X-ray structure of bis(di(2-hydroxyethyl)dithiocarbamato)zinc(II). J. Coord. Chem. 1998, 44, 281-288. [CrossRef]

85. Poplaukhin, P.; Tiekink, E.R.T. A triclinic polymorph of bis $(\mu-N, N$-bis(2-hydroxyethyl)-dithiocarbamato$\left.\kappa^{3} S, S^{\prime}: S^{\prime}\right)$ bis(N,N-bis(2-hydroxyethyl)- $\left.\kappa^{2} \mathrm{~S}: \mathrm{S}^{\prime}\right)$ zinc(II), $\mathrm{C}_{20} \mathrm{H}_{40} \mathrm{~N}_{4} \mathrm{O}_{8} \mathrm{~S}_{8} \mathrm{Zn}_{2}$. Z. Kristallogr. New Cryst. Struct. 2018, 233, 529-531. [CrossRef]

86. Shahdid, M.; Ruffer, T.; Lang, H.; Awan, S.A.; Ahmad, S. Synthesis and crystal structure of a dinuclear zinc(II)-dithiocarbamate complex, bis $\left\{\left[\left(\mu^{2}\right.\right.\right.$-pyrrolidinedithiocarbamato-S, $\left.S^{\prime}\right)$ (pyrrolidinedithiocarbamato-S,S')zinc(II)]\}. J. Coord. Chem. 2009, 62, 440-445. [CrossRef]

87. Shaheen, F.; Gieck, C.; Badshah, A.; Khosa, M.K. Bis( $\mu$-piperidine-1-dithiocarboxylato- $\left.\kappa^{2} \mathrm{~S}: \mathrm{S}^{\prime}\right)[$ bis(piperidine1-dithiocarboxylato- $\left.\left.{ }^{2} \mathrm{~S}, \mathrm{~S}^{\prime}\right) \mathrm{zinc}(\mathrm{II})\right]$. Acta Crystallogr. Sect. E Struct. Rep. Online 2006, 62, m1186-m1187. [CrossRef]

88. Agre, V.M.; Shugam, E.A. Structures of inner complex compounds with M-S bonds. 9. Crystal and molecular structures of zinc hexamethylenedithiocarbamate. J. Struct. Chem. 1972, 13, 614-618. [CrossRef]

89. Shaheen, F.; Gieck, C.; Badshah, A. Bis( $\mu-4-$ methylpiperidine-1-dithiocarboxylato- ${ }^{2} S: S$ ')-[bis(4methylpiperidine-1-dithiocarboxylato-S:S')zinc(II)]. Acta Crystallogr. Sect. E Struct. Rep. Online 2006, 62, m16-m17. [CrossRef]

90. Lecina, J.; Carrer, A.; Alvarez-Larena, A.; Mazzi, U.; Melendez-Alafort, L.; Suades, J. New bioconjugated rhenium carbonyls by transmetalation reaction with zinc derivatives. Organometallics 2012, 31, 5884-5893. [CrossRef]

91. Wang, Y.; Yan, L.-H.; Lu, L.-D. Crystal structure and characterization of Bis[di(N'-ethyl-Npiperazinly-carbodithioato-S,S')zinc(II)] complexes: $\left[\mathrm{Zn}_{2}\left(\mathrm{~S}_{2} \mathrm{CNC}_{4} \mathrm{H}_{8} \mathrm{NC}_{2} \mathrm{H}_{5}\right)_{4}\right]$. Chin. J. Inorg. Chem. 2006, 22, 1728-1732.

92. Bharti, A.; Bharati, P.; Chaudhari, U.K.; Singh, A.; Kushawaha, S.K.; Singh, N.K.; Bharty, M.K. Syntheses, crystal structures and photoluminescent properties of new homoleptic and heteroleptic zinc(II) dithiocarbamato complexes. Polyhedron 2015, 85, 712-719. [CrossRef]

93. Zia-ur-Rehman; Ibrahim, S.; Khan, A.; Imran, M.; Naseer, M.M.; Khanb, I.; Shah, A.; Tahir, M.N.; Muneeb-ur-Rahman; Awan, I.Z. Homobimetallic zinc(II) dithiocarbamates: Synthesis, characterization and in vivo antihyperglycemic activity. J. Coord. Chem. 2016, 69, 551-561. [CrossRef]

94. Motevalli, M.; O’Brien, P.; Walsh, J.R.; Watson, I.M. Synthesis, characterization and x-ray crystal structures of asymmetric bis(dialkyldithiocarbamates) of zinc: Potential precursors for ZnS deposition. Polyhedron 1996, 15, 2801-2808. [CrossRef]

95. Baba, I.; Lee, L.H.; Farina, Y.; Othman, A.H.; Ibrahim, A.R.; Usman, A.; Fun, H.-K.; Ng, S.W. Bis( $\mu$-N-methylN-phenyldithiocarbamato)[bis(N-methyl-N-phenyldithiocarbamato)zinc(II)]. Acta Crystallogr. Sect. E Struct. Rep. Online 2002, 58, m744-m745. [CrossRef]

96. Tan, Y.S.; Ooi, K.K.; Ang, K.P.; Akim, A.M.; Cheah, Y.-K.; Halim, S.N.A.; Seng, H.-L.; Tiekink, E.R.T. Molecular mechanisms of apoptosis and cell selectivity of zinc dithiocarbamates functionalized with hydroxyethyl substituents. J. Inorg. Biochem. 2015, 150, 48-62. [CrossRef] [PubMed] 
97. Nagy, E.M.; Sitran, S.; Montopoli, M.; Favaro, M.; Marchio, L.; Ronconi, L.; Caparrotta, L.; Fregona, D. Zinc(II) complexes with dithiocarbamato derivatives: Structural characterisation and biological assays on cancerous cell lines. J. Inorg. Biochem. 2012, 117, 131-139. [CrossRef] [PubMed]

98. Ferreira, I.P.; de Lima, G.M.; Paniago, E.B.; Pinheiro, C.B.; Wardell, J.L.; Wardell, S.M.S.V. Study of metal dithiocarbamate complexes, Part V. Metal complexes of $\left[\mathrm{S}_{2} \mathrm{CN}\left(\mathrm{CH}_{2} \mathrm{CH}(\mathrm{OMe})_{2}\right]\right.$ : A standard dimeric zinc dithiocarbamate structural motive, a rare cadmium dithiocarbamate coordination polymer, and a hydrated sodium dithiocarbarmate complex, with a $\left[\mathrm{Na}_{2} \mathrm{O}_{2}\right]$ core and chain. Inorg. Chim. Acta 2016, 441, 137-145. [CrossRef]

99. Baba, I.; Farina, Y.; Othman, A.H.; Razak, I.A.; Fun, H.-K.; Ng, S.W. Bis( $\mu-\mathrm{N}-\mathrm{ethyl-N-}$ isopropyldithiocarbamato-S:S')bis[(N-ethyl-N-isopropyldithiocarbamato-S,S')zinc(II)]. Acta Crystallogr. Sect. E Struct. Rep. Online 2001, 57, m51-m52. [CrossRef]

100. Baba, I.; Farina, Y.; Kassim, K.; Othman, A.H.; Razak, I.A.; Fun, H.-K.; Ng, S.W. Bis( $\mu-N-b u t y l-N-e t h y l$ dithiocarbamato-S:S')bis[(N-butyl-N-ethyldithiocarbamato)zinc(II)]. Acta Crystallogr. Sect. E Struct. Rep. Online 2001, 57, m55-m56. [CrossRef]

101. Ajibade, P.A.; Mbese, J.Z.; Omondi, B. Group 12 dithiocarbamate complexes: Synthesis, characterization, and X-ray crystal structures of $\mathrm{Zn}(\mathrm{II})$ and $\mathrm{Hg}$ (II) complexes and their use as precursors for metal sulfide nanoparticles. Inorg. Nano-Met. Chem. 2017, 47, 202-212. [CrossRef]

102. Gossage, R.A.; Jenkins, H.A. The crystal structure of bis $\left(\mu-N-e t h y l-N-p h e n y l d i t h i o c a r b a m a t o-S, S^{\prime}\right)-b i s[(N-$ ethyl-N-phenyldithiocarbamato-k²S,S')zinc(II)]. Acta Chim. Slov. 2009, 56, 329-333.

103. Tan, Y.S.; Tiekink, E.R.T. Crystal structure of bis $\left(\mu-N-i-p r o p y l-N-n-p r o p y l d i t h i o c a r b a m a t o-\kappa^{2} S: S^{\prime}\right)$ bis(N-i-propyl-N-n-propyldithiocarbamato- $\left.{ }^{2} \mathrm{~S}, \mathrm{~S}^{\prime}\right)$ dizinc(II), $\mathrm{C}_{28} \mathrm{H}_{56} \mathrm{~N}_{4} \mathrm{~S}_{8} \mathrm{Zn}_{2}$. Z. Kristallogr. New Cryst. Struct. 2018, 233, 477-479. [CrossRef]

104. Sathiyaraj, E.; Perumal, M.V.; Nagarajan, E.R.; Ramalingan, C. Functionalized zinc(II) dithiocarbamate complexes: Synthesis, spectral and molecular structures of bis(N-cyclopropyl-N-4-methoxybenzyldithio carbamato-S,S')zinc(II) and (2,2'-bipyridine)bis(N-cyclopropyl-N-4-methoxybenzyldithio carbamato-S,S')zinc(II). J. Saudi Chem. Soc. 2017, in press. [CrossRef]

105. Ajibade, P.A.; Onwudiwe, D.C. Synthesis and characterization of group 12 complexes of N,N-methyl phenyl-N,N-butyl phenyl dithiocarbamate. J. Coord. Chem. 2011, 64, 2963-2973. [CrossRef]

106. Jia, C.-M.; Yuan, W.-B.; Lin, Q.; Zhang, Q.; Pei, J. Bis( $\left.\mu-N-b e n z y l-N-t e t r a d e c y l d i t h i o c a r b a m a t o-\kappa^{2} S: S^{\prime}\right) b i s[(N-$ benzyl-N-tetradecyldithiocarbamato-k $\left.{ }^{2} \mathrm{~S}, \mathrm{~S}^{\prime}\right)$ zinc(II)]. Acta Crystallogr. Sect. E Struct. Rep. Online 2009, 65, m471. [CrossRef] [PubMed]

107. Ivanov, A.V.; Ivakhnenko, E.V.; Forsling, W.; Gerasimenko, A.V. Single-crystal X-ray diffraction and $\mathrm{CP} / \mathrm{MAS}{ }^{13} \mathrm{C}$ and ${ }^{15} \mathrm{~N}$ NMR study of zinc $\mathrm{N}, \mathrm{N}$-di-iso-butyldithiocarbamate Ccomplex: A unique structural organization. Doklady Chem. 2003, 390, 162-167. [CrossRef]

108. Halim, S.N.A. Pers. Commun. Camb. Str. Database, 2015. Refcode: QUQTED.

109. Kumar, V.; Manar, K.K.; Gupta, A.N.; Singh, V.; Drew, M.G.B.; Singh, N. Impact of ferrocenyl and pyridyl groups attached to dithiocarbamate moieties on crystal structures and luminescent characteristics of group 12 metal complexes. J. Organomet. Chem. 2016, 820, 62-69. [CrossRef]

110. Poplaukhin, P.; Arman, H.D.; Tiekink, E.R.T. A one-dimensional coordination polymer, catena-poly[[[[Nethyl-N-(pyridin-4-ylmethyl)dithiocarbamato- $\left.\kappa^{2} \mathrm{~S}, \mathrm{~S}^{\prime}\right]$ zinc(II)]- $\mu^{2}-\mathrm{N}$-ethyl-N-(pyridin-4-ylmethyl)dithiocarbamato$\left.\kappa^{3} \mathrm{~S}, \mathrm{~S}^{\prime}: \mathrm{N}\right]$ 4-methylpyridine hemisolvate]. Acta Crystallogr. Sect. E Cryst. Commun. 2017, 73, 1162-1166. [CrossRef] [PubMed]

111. Casas, J.S.; Sanchez, A.; Bravo, J.; Garcia-Fontan, S.; Castellano, E.E.; Jones, M.M. Cadmium coordination chemistry related to chelate therapy. Inorg. Chim. Acta 1989, 158, 119-126. [CrossRef]

112. Domenicano, A.; Torelli, L.; Vaciago, A.; Zambonelli, L. Structural studies of metal dithiocarbamates. Part IV. The crystal and molecular structure of cadmium(II)NN-diethyldithiocarbamate. J. Chem. Soc. A 1968, 1351-1361. [CrossRef]

113. Dee, C.M.; Tiekink, E.R.T. Refinement of the crystal structure of dimeric bis(N,N-diethyldithiocarbamato) cadmium(II), [Cd( $\left.\left.\mathrm{S}_{2} \mathrm{CNEt}_{2}\right)_{2}\right]_{2}$. Z. Kristallogr. New Cryst. Struct. 2002, 217, 85-86. [CrossRef]

114. Jian, F.-F.; Wang, Z.-X.; Bai, Z.-P.; You, X.-Z.; Fun, H.-K.; Chinnakali, K. Structure of bis(dipropyldithiocarbamate) cadmium(II), $\left[\mathrm{Cd}_{2}\left(\mathrm{n}-\mathrm{Pr}_{2} \mathrm{dtc}\right)_{4}\right](\mathrm{dtc}=$ dithiocarbamate). J. Chem. Crystallogr. 1999, 29, 227-231. [CrossRef] 
115. Jian, F.-F.; Wang, Z.-X.; Fun, H.-K.; Bai, Z.-P.; You, X.-Z. A binuclear cadmium(II) complex: Bis[bis(N,Ndiisopropyldithiocarbamato)cadmium(II)]. Acta Crystallogr. Sect. C Cryst. Struct. Commun. 1999, 55, 174-176. [CrossRef]

116. Onwudiwe, D.C.; Hrubaru, M.; Hosten, E.C.; Arderne, C. Bis( $\mu-\mathrm{N}, \mathrm{N}-$ diallyldithiocarbamato)bis $[(\mathrm{N}, \mathrm{N}-$ diallyldithiocarbamato)cadmium]. Acta Crystallogr. Sect. E Cryst. Commun. 2017, 73, 1353-1356. [CrossRef] [PubMed]

117. Glinskaya, L.A.; Zemskova, S.M.; Klevtsova, R.F. Molecular and crystal, structure of cadmium(II) diisobutyldithiocarbamate $\left\{\mathrm{Cd}\left[\left(\mathrm{i}-\mathrm{C}_{4} \mathrm{H}_{9}\right)_{2} \mathrm{NCS}_{2}\right]_{2}\right\}_{2}$. J. Struct. Chem. 1999, 40, 979-983. [CrossRef]

118. Cox, M.J.; Tiekink, E.R.T. Structural characteristics of cadmium(II) bis(N,N-dialkyldithiocarbamate) compounds. Z. Kristallogr. 1999, 214, 670-676. [CrossRef]

119. Yin, X.; Zhang, W.; Zhang, Q.; Fan, J.; Lai, C.S.; Tiekink, E.R.T. Crystallographic report: Bis[bis(N,N-dibenzyldithiocarbamato)cadmium(II)]. Appl. Organomet. Chem. 2004, 18, 139-140. [CrossRef]

120. Saravanan, M.; Ramalingam, K.; Bocelli, G.; Olla, R. Refinement of the crystal structure of dimeric bis(N,N-diethyldithiocarbamato) cadmium(II), $\left[\mathrm{Cd}\left(\mathrm{S}_{2} \mathrm{CNEt}_{2}\right)_{2}\right]_{2}$. Appl. Organomet. Chem. 2004, 18, 103. [CrossRef]

121. Zhong, Y.; Zhang, W.; Fan, J.; Tan, M.; Lai, C.S.; Tiekink, E.R.T. Bis $\mu-N, N-b i s(2-h y d r o x y e t h y l)$ dithiocarbamato $]-1: 2 \kappa^{3} S, S^{\prime}: S^{\prime} ; 2: 1 \kappa^{3} S, S^{\prime}: S^{\prime}$-bis $\left\{\left[N, N-b i s(2-h y d r o x y e t h y l) d i t h i o c a r b a m a t o-\kappa^{2} S, S^{\prime}\right]\right.$ cadmium(II) . Acta Crystallogr. Sect. E Struct. Rep. Online 2004, 60, m1633-m1635. [CrossRef]

122. Ivanov, A.V.; Gerasimenko, A.V.; Konzelko, A.A.; Ivanov, M.A.; Antzutkin, O.N.; Forsling, W. Conformational isomerism of the binuclear N,N-pentamethylenedithiocarbamate cadmium(II) complex, $\left[\mathrm{Cd}_{2}\left\{\mathrm{~S}_{2} \mathrm{CN}\left(\mathrm{CH}_{2}\right)_{5}\right\}_{4}\right]$ on multinuclear $\left({ }^{15} \mathrm{~N},{ }^{113} \mathrm{Cd}\right) \mathrm{CP} / \mathrm{MAS} \mathrm{NMR}$ and single-crystal X-ray diffraction data. Inorg. Chim. Acta 2006, 359, 3855-3864. [CrossRef]

123. Manohar, A.; Ramalingam, K.; Bocelli, G.; Cantoni, A. Synthesis and spectral studies on 2:1 adducts involving cadmium dithiocarbamates and 4,4'-bipyridine. Single crystal X-ray structural studies on bis(piperidinecarbodithioato-S,S')cadmium(II) benzene solvate. Pol. J. Chem. 2005, 79, 671-678.

124. Thirumaran, S.; Srinivasan, N.; Sharma, V.; Gupta, V.K. Rajnikant, Crystal Structure of Bis( $\mu$-4-methylpiperidine-1-carbodithioato- $\left.1: 2 \kappa^{3} S, S^{\prime}: S^{\prime} ; 2: 1 \kappa^{3} S, S^{\prime}: S^{\prime}\right)$ bis [(4-methylpiperidine-1-carbodithioato$\left.\kappa^{2} \mathrm{~S}, \mathrm{~S}^{\prime}\right)$ cadmium(II)]. X-ray Struct. Anal. Online 2012, 28, 21-22. [CrossRef]

125. Zaeva, A.S.; Ivanov, A.V.; Gerasimenko, A.V. Adduct formation of cadmium(II) N,N-cyclohexamethylenedithiocarbamate, $\left[\mathrm{Cd}_{2}\left\{\mathrm{~S}_{2} \mathrm{CN}\left(\mathrm{CH}_{2}\right)_{6}\right\}_{4}\right]$, with morpholine: Synthesis, molecular structure, and thermal behavior of a crystalline adduct cis- $\left[\mathrm{Cd}\left\{\mathrm{NH}\left(\mathrm{CH}_{2}\right)_{4}\right) \mathrm{O}_{2}\left\{\mathrm{~S}_{2} \mathrm{CN}\left(\mathrm{CH}_{2}\right)_{6}\right\}_{2}\right]$. Russ. J. Coord. Chem. 2014, 40, 34-42. [CrossRef]

126. Suwardi, S.A.N.; Lee, S.M.; Lo, K.M.; Jotani, M.M.; Tiekink, E.R.T. Bis $\left(\mu_{2}-\mathrm{N}-\mathrm{methyl}\right.$ $\mathrm{N}$-phenyldithiocarbamato)- $\kappa^{3} \mathrm{~S}, \mathrm{~S}^{\prime}: \mathrm{S} ; \mathrm{K}^{3} \mathrm{~S}: \mathrm{S}, \mathrm{S}^{\prime}$-bis$\left[\left(\mathrm{N}\right.\right.$-methyl-N-phenyldithiocarbamato- $\left.\mathrm{K}^{2} \mathrm{~S}, \mathrm{~S}^{\prime}\right)$ cadmium]: Crystal structure and Hirshfeld surface analysis. Acta Crystallogr. Sect. E Cryst. Commun. 2017, 73, 429-433. [CrossRef] [PubMed]

127. Tan, Y.S.; Tiekink, E.R.T. Crystal structure of bis $\left(\mu-\mathrm{N}-\mathrm{i}-\right.$ propyl-N-n-propyldithiocarbamato- $\left.\kappa^{2} \mathrm{~S}: \mathrm{S}^{\prime}\right)$ bis(N-i-propyl-N-n-propyldithiocarbamato-k $\left.{ }^{2} \mathrm{~S}, \mathrm{~S}^{\prime}\right)$ dicadmium(II), $\mathrm{C}_{28} \mathrm{H}_{56} \mathrm{Cd}_{2} \mathrm{~N}_{4} \mathrm{~S}_{8}$. Z. Kristallogr. New Cryst. Struct. 2018, 233, 481-483. [CrossRef]

128. Tan, Y.S.; Sudlow, A.L.; Molloy, K.C.; Morishima, Y.; Fujisawa, K.; Jackson, W.J.; Henderson, W.; Halim, S.N.Bt.A.; Ng, S.W.; Tiekink, E.R.T. Supramolecular isomerism in a cadmium bis(N-hydroxyethyl, $\mathrm{N}$-isopropyldithiocarbamate) compound: Physiochemical characterization of ball $(\mathrm{n}=2)$ and chain $(\mathrm{n}=\infty)$ forms of $\left\{\mathrm{Cd}\left[\mathrm{S}_{2} \mathrm{CN}(\mathrm{iPr}) \mathrm{CH}_{2} \mathrm{CH}_{2} \mathrm{OH}\right]_{2} \text {. solvent }\right\}_{\mathrm{n}}$. Cryst. Growth Des. 2013, 13, 3046-3056. [CrossRef]

129. Tan, Y.S.; Halim, S.N.A.; Tiekink, E.R.T. Exploring the crystallization landscape of cadmium bis(N-hydroxyethyl, $\mathrm{N}$-isopropyl-dithiocarbamate), $\mathrm{Cd}\left[\mathrm{S}_{2} \mathrm{CN}(\mathrm{iPr}) \mathrm{CH}_{2} \mathrm{CH}_{2} \mathrm{OH}\right]_{2}$. Z. Kristallogr. 2016, 231, 113-126. [CrossRef]

130. Kant, R.; Gupta, V.K.; Kapoor, K.; Valarmathi, P.; Thirumaran, S. Bis( $\mu$-N-benzyl-N-furfuryldithiocarbamato)$1: 2 \kappa^{3} S, S^{\prime}: S^{\prime} ; 2: 1 \kappa^{3} S, S^{\prime}: S^{\prime}$-bis[(N-benzyl-N-furfuryldithiocarbamato-k $\left.{ }^{2} S, S^{\prime}\right)$ cadmium]. Acta Crystallogr. Sect. E Struct. Rep. Online 2012, 68, m12-m13. [CrossRef] [PubMed]

131. Manar, K.K.; Yadav, M.K.; Anamika; Drew, M.G.B.; Singh, N. Influence of functionalities over polymer, trimer, dimer formation and optical properties of cadmium dithiocarbamates. Polyhedron 2016, 117, 592-599. [CrossRef] 
132. O'Brien, P.; Walsh, J.R.; Watson, I.M.; Motevalli, M.; Henriksen, L. Novel dithio- and diseleno-carbamates of zinc and cadmium as single-molecule precursors for low-pressure metal-organic chemical vapour deposition. J. Chem. Soc. Dalton Trans. 1996, 2491-2496. [CrossRef]

133. Kumar, V.; Singh, V.; Gupta, A.N.; Manar, K.K.; Drew, M.G.B.; Singh, N. Influence of ligand environments on the structures and luminescence properties of homoleptic cadmium(II) pyridyl functionalized dithiocarbamates. CrystEngComm 2014, 16, 6765-6774. [CrossRef]

134. Clegg, W.; Coxall, R.A. Pers. Commun. Camb. Str. Database, 2016. Refcode: OJEQUR.

135. Arman, H.D.; Poplaukhin, P.; Tiekink, E.R.T. A two-dimensional coordination polymer: Poly[[bis $\left[\mu_{2}-\mathrm{N}-\mathrm{ethyl-}\right.$ $\mathrm{N}$-(pyridin-4-ylmethyl)dithiocarbamato- $\left.{ }^{3} \mathrm{~N}: \mathrm{S}, \mathrm{S}^{\prime}\right]$ cadmium(II)] 3-methylpyridine monosolvate]. Acta Crystallogr. Sect. E Cryst. Commun. 2017, 73, 488-492. [CrossRef] [PubMed]

136. Bing, Y.; Li, X.; Zha, M.; Lu, Y. catena-Poly[cadmium-bis( $\left.\left.\mu-N, N-d i m e t h y l d i t h i o c a r b a m a t o-\kappa^{3} S, S^{\prime}: S\right)\right]$. Acta Crystallogr. Sect. E Struct. Rep. Online 2010, 66, m1500. [CrossRef] [PubMed]

137. Moulton, B.; Zaworotko, M.J. From molecules to crystal engineering: supramolecular isomerism and polymorphism in network solids. Chem. Rev. 2001, 101, 1629-1658. [CrossRef] [PubMed]

138. Tiekink, E.R.T. Supramolecular assembly based on "emerging" intermolecular interactions of particular interest to coordination chemists. Coord. Chem. Rev. 2017, 345, 209-228. [CrossRef]

139. Ito, M.; Iwasaki, H. The structure of the monomeric form of mercury(II) N,N-diisopropyldithiocarbamate [bis(N,N-diisopropyldithiocarbamato)mercury(II)]. Acta Crystallogr. Sect. B Struct. Crystallogr. Cryst. Chem. 1979, 35, 2720-2721. [CrossRef]

140. Cox, M.J.; Tiekink, E.R.T. The crystal structure of monomeric bis(dicyclohexyldithiocarbamato)mercury(II). Main Group Met. Chem. 2000, 23, 793-794. [CrossRef]

141. Lai, C.S.; Tiekink, E.R.T. Bis(N,N-dibenzyldithiocarbamato)mercury(II). Appl. Organomet. Chem. 2004, 18, 104. [CrossRef]

142. Lai, C.S.; Tiekink, E.R.T. Bis(pyrrolinedithiocarbamato)mercury(II). Appl. Organomet. Chem. 2003, $17,143$. [CrossRef]

143. Cox, M.J.; Tiekink, E.R.T. Structural diversity in the mercury(II) bis(N,N-dialkyldithiocarbamate) compounds: An example of the importance of considering crystal structure when rationalising molecular structure. Z. Kristallogr. 1999, 214, 571-579. [CrossRef]

144. Marimuthu, G.; Ramalingam, K.; Rizzoli, C. Predominant ionic interactions in $\mathrm{CdS}_{4} \mathrm{~N}_{2}$ and $\mathrm{HgS}_{4}$ coordination environments. J. Coord. Chem. 2013, 66, 699-711. [CrossRef]

145. Srinivasan, N.; Thirumaran, S.; Ciattini, S. Effect of co-crystallization of ethanol, pyridine and 2,2'-bipyridine on molecular aggregation in bis(1,2,3,4-tetrahydroquinolinedithiocarbamato- $\left.\mathrm{S}, \mathrm{S}^{\prime}\right)$ mercury(II) and synthesis of $\mathrm{HgS}$ nanoparticles. RSC Adv. 2014, 4, 22971-22979. [CrossRef]

146. Yadav, M.K.; Rajput, G.; Gupta, A.N.; Kumar, V.; Drew, M.G.B.; Singh, N. Exploring the coordinative behaviour and molecular architecture of new $\mathrm{PhHg}(\mathrm{II}) / \mathrm{Hg}(\mathrm{II})$ dithiocarbamate complexes. Inorg. Chim. Acta 2014, 421, 210-217. [CrossRef]

147. Kumar, A.; Chauhan, R.; Molloy, K.C.; Kociok-Kohn, G.; Bahadur, L.; Singh, N. Synthesis, structure and light-harvesting properties of some new transition-metal dithiocarbamates involving ferrocene. Chem.-Eur. J. 2010, 16, 4307-4314. [CrossRef] [PubMed]

148. Cox, M.J.; Tiekink, E.R.T. Structural variations in the mercury(II) bis(1,1-dithiolate)s: The crystal and molecular structure of $\left[\mathrm{Hg}\left(\mathrm{S}_{2} \mathrm{CNMe}_{2}\right)_{2}\right]$. Z. Kristallogr. 1997, 212, 542-544. [CrossRef]

149. Iwasaki, H. The crystal structure of dimeric and monomeric forms of mercury(II) N,Ndiethyldithiocarbamate, $\mathrm{Hg}_{2}\left(\mathrm{~S}_{2} \mathrm{CNEt}_{2}\right)_{4}$ and $\mathrm{Hg}\left(\mathrm{S}_{2} \mathrm{CNEt}_{2}\right)_{2}$. Acta Crystallogr. Sect. B Struct. Crystallogr. Cryst. Chem. 1973, 29, 2115-2124. [CrossRef]

150. Singh, V.; Kumar, A.; Prasad, R.; Rajput, G.; Drew, M.G.B.; Singh, N. The interplay of secondary $\mathrm{Hg} \cdots \mathrm{S}, \mathrm{Hg} \cdots \mathrm{N}$ and $\mathrm{Hg} \cdots \pi$ bonding interactions in supramolecular structures of phenylmercury(II) dithiocarbamates. CrystEngComm 2011, 13, 6817-6826. [CrossRef]

151. Howie, R.A.; Tiekink, E.R.T.; Wardell, J.L.; Wardell, S.M.S.V. Complementary supramolecular aggregation via $\mathrm{O}-\mathrm{H} \cdots \mathrm{O}$ hydrogen-bonding and $\mathrm{Hg} \cdots \mathrm{S}$ interactions in bis[ $\mathrm{N}, \mathrm{N}^{\prime}$-di(2-hydroxyethyl)dithiocarbamato-S, $\left.\mathrm{S}^{\prime}\right]$ mercury(II): $\mathrm{Hg}\left[\mathrm{S}_{2} \mathrm{CN}\left(\mathrm{CH}_{2} \mathrm{CH}_{2} \mathrm{OH}\right)_{2}\right]_{2}$. J. Chem. Crystallogr. 2009, 39, 293-298. [CrossRef]

152. Gurumoorthy, G.; Thirumaran, S.; Ciattini, S. Unusual octahedral Hg(II) dithiocarbamate: Synthesis, spectral and structural studies on $\mathrm{Hg}$ (II) complexes with pyrrole based dithiocarbamates and their utility for the preparation of $\alpha$ - and $\beta$-HgS. Polyhedron 2016, 118, 143-153. [CrossRef] 
153. Lai, C.S.; Tiekink, E.R.T. Refinement of the crystal structure of bis[bis(N,N-diethyldithiocarbamato) mercury(II)], $\left[\mathrm{Hg}\left(\mathrm{S}_{2} \mathrm{CNEt}_{2}\right)_{2}\right]_{2}$. Z. Kristallogr. New Cryst. Struct. 2002, 217, 593-594. [CrossRef]

154. Loseva, O.V.; Rodina, T.A.; Smolentsev, A.I.; Ivanov, A.V. A new polymorphic modification and chemisorption activity of mercury(II) N,N-di-iso-propyldithiocarbamate: Synthesis and characterisation of the heteronuclear double complex of $\left(\left[\mathrm{Au}\left\{\mathrm{S}_{2} \mathrm{CN}\left(\text { iso- } \mathrm{C}_{3} \mathrm{H}_{7}\right)_{2}\right\}_{2}\right]_{2}\left[\mathrm{Hg}_{2} \mathrm{Cl}_{6}\right] \cdot \mathrm{OC}\left(\mathrm{CH}_{3}\right)_{2}\right)_{\mathrm{n}}$. Polyhedron 2017, 134, 238-245. [CrossRef]

155. Altaf, M.; Stoeckli-Evans, H.; Batool, S.S.; Isab, A.A.; Ahmad, S.; Saleem, M.; Awan, S.A.; Shaheen, M.A. Mercury(II) complexes of pyrrolidinedithiocarbamate, crystal structure of bis $\left\{\left[\mu_{2}-\right.\right.$ (pyrrolidinedithiocarbamato-S, $\left.\mathrm{S}^{\prime}\right)$ (pyrrolidinedithiocarbamato-S, $\left.\mathrm{S}^{\prime}\right)$ mercury(II)]\}. J. Coord. Chem. 2010, 63, 1176-1185. [CrossRef]

156. Benedetti, A.; Fabretti, A.C.; Preti, C. Structure, IR, and NMR spectra of tetrakis(4-methyl piperidinedithiocarbamate) dimercury(II). J. Crystallogr. Spectrosc. Res. 1988, 18, 685-692. [CrossRef]

157. Ivanov, A.V.; Korneeva, E.V.; Bukvetskii, B.V.; Goryan, A.S.; Antsutkin, O.N.; Forshling, W. Structural organization of mercury(II) and copper(II) dithiocarbamates from EPR and C-13 and N-15 MAS NMR spectra and X-ray diffraction analysis. Russ. J. Coord. Chem. 2008, 34, 59-69. [CrossRef]

158. Gomathi, G.; Dar, S.H.; Thirumaran, S.; Ciattini, S.; Selvanayagam, S. Bis(N-benzyl-N-furfuryldithiocarbamato$\left.\mathrm{S}, \mathrm{S}^{\prime}\right)$ mercury(II) as a precursor for the preparation of mercury sulfide nanoparticles. Compt. Rend. Chim. 2015, 18, 499-510. [CrossRef]

159. Onwudiwe, D.C.; Ajibade, P. Synthesis, characterization and thermal studies of $\mathrm{Zn}(\mathrm{II}), \mathrm{Cd}(\mathrm{II})$ and $\mathrm{Hg}$ (II) complexes of N-methyl-N-phenyldithiocarbamate: The single crystal structure of $\left[\left(\mathrm{C}_{6} \mathrm{H}_{5}\right)\left(\mathrm{CH}_{3}\right) \mathrm{NCS}_{2}\right]_{4} \mathrm{Hg}_{2}$. Int. J. Mol. Sci. 2011, 12, 1964-1978. [CrossRef] [PubMed]

160. Green, M.; Prince, P.; Gardener, M.; Steed, J. Mercury(II) N,N'-methyl-phenylethyl-dithiocarbamate and its use as a precursor for the room-temperature solution deposition of $\beta-\mathrm{HgS}$ thin films. Adv. Mater. 2004, 16, 994-996. [CrossRef]

161. Ondrušová, D.; Pajtášová, M.; Jóna, E.; Koman, M. Structural properties of $\mathrm{Co}(\mathrm{III}), \operatorname{Hg}(\mathrm{II})$ and $\mathrm{Pb}$ (II) N-ethyl-N-phenyldithiocarbamates and their application in the rubber industry. Solid State Phenom. 2003, 90-91, 383-388. [CrossRef]

162. Jotani, M.M.; Tan, Y.S.; Tiekink, E.R.T. Bis[bis(N-2-hydroxyethyl, N-isopropyl-dithiocarbamato)mercury(II) $]_{2}$ : Crystal structure and Hirshfeld surface analysis. Z. Kristallogr. 2016, 231, 403-413. [CrossRef]

163. Dar, S.H.; Thirumaran, S.; Selvanayagam, S. Synthesis, spectral and X-ray structural studies on Hg(II) dithiocarbamate complexes: A new precursor for HgS nanoparticles. Polyhedron 2015, 96, 16-24. [CrossRef] 